غسيل الأموال الحرام ِِّ العمل الخيري

\title{
حكمه وضوابطه
}

"ِِّ ضوء نصوص مذاهب الفقه، وأدلته، ومقاصده الكليتة"

إعداد: د. أحمد علي أحمد موافي

قسم الشريعة الإسلامية بكلية دار العلوم -

$$
\text { جامعة القاهرة }
$$

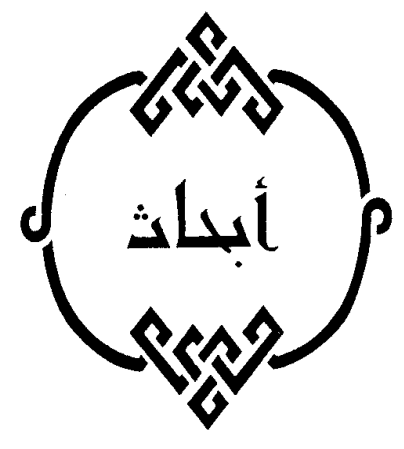

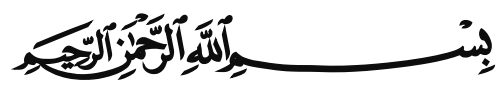

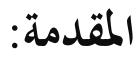

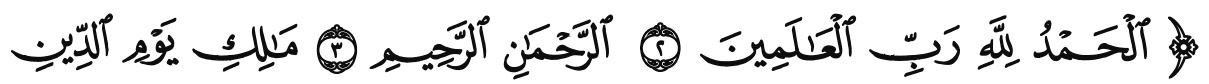

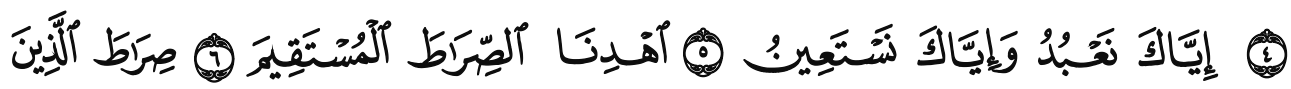

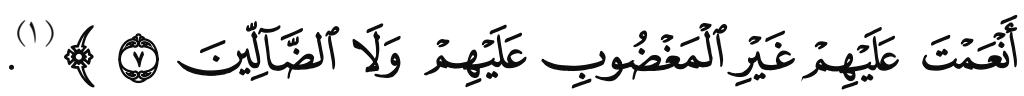

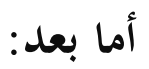

فقد اهتمت شرعة الإسلام بالمال اهتماما كبيرا، فمن ناحية الحصول عليه حددت سبل كسبه ليكون حلالا، ومن ناحية إنفاقه جعلت لذلك ضوابط تكفل له أن يعمل في مكانه الصحيح؛ انطلاقا مما جاء عن الله في قرآنه وعن النبي إنعاهـ 
ـ صلى الله عليه وسلم - في سنته تحصيلا لمصالح الناس وتكميلها وتعطيلا للمضار وتقليلها وفق منهجية الإسلام، فالمال مسؤولية يسأل عنه صاحبه أمام

$$
\text { ربه: من أين اكتسبه؟ وفيم أنفقه؟ ونعائه }
$$

فيجب على المسلم أن يتحرى الحلال في جمع المال، والصحة في إنفاقه، ومن إنسهن

تم تبرز أهمية هذا الموضوع: موضوع (غسيل الأموال الحرام في العمل الحيري:

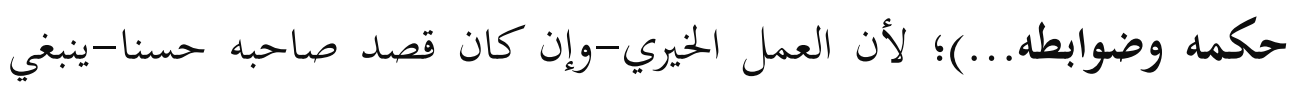

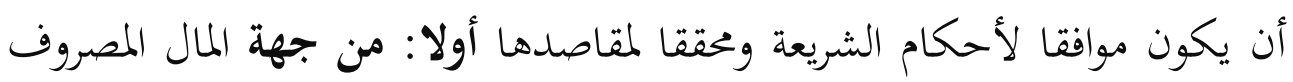
فيه فليس يقبل كل مال في العمل الخيري، وثانيا: من جهة الضوابط والمعايير

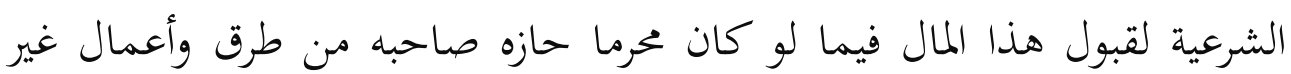
مشروعة وأراد أن يغسله ويتطهر منه بإنفاقه في عمل خيري.

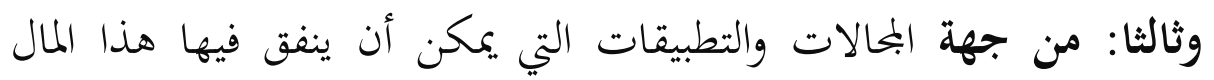
المغسول. وسوف نحاول من خلال هذا البحث عرض هذه الأمور الثلاثة بشيء من

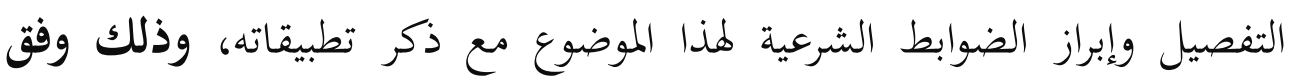
الخطة التالية:

المبحث الأول: التعريف بالمصطلحات الواردة في عنوان البحث،

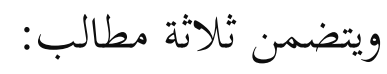
المطلب الأول: مفهوم غسيل الأموال الحرام المطلب الثاني: التعريف بالعمل الخيري المطلب الثالث: تعريف الحكم والضوابط لغة واصطلاحا المبحث الثاني : أقسام المال الحرام، وأهم صوره ، ويتضمن مطلبين: 


$$
\text { المطلب الأول: أقسام المال الحرام. }
$$

المبحث الثالث : التأصيل الشرعي لقبول المال المغسول والانتفاع به في العمل الحيري ، ويتضمن مطلبين:

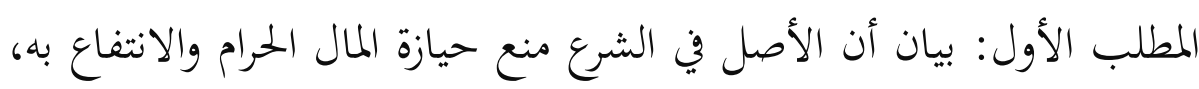
وتجريم اكتسابه، ووجوب التخلص منه.

المطلب الثاني : احتمالات التخلص من ملكية المال المغسول والتصرف فيه.

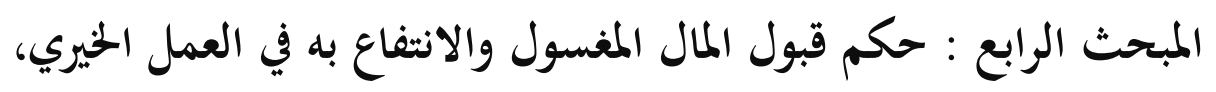
وضوابط ذلك ، ويتضمن مطلبين:

المطلب الأول: حكم قبول المال المغسول والانتفاع به في العمل الخيري. المطلب الثاني: ضوابط قبول المال المغسول، وتطبيقاته في العمل الخيري.

$$
\text { فهرس المصادر والمراجع }
$$




\section{الابدمث الأول \\ التعريف بالامسطاحات الواردة في عنوان البعث}

ويشمل هذا المبحث ثلاثة مطالب:

المطلب الأول

مفهوم غسيل الأموال الحرام

أولا: مفهوم غسيل الأموال:

يستحوذ مفهوم مصطلح: "غسيل الأموال" على اهتمام صانعي السياسات

الاقتصادية والمالية وبالتحديد القائمين على السياسات النقدية والمصرفية سواء محليا، أم إقليميا، أم عالميا، ورغم ذلك لا يمكن إيجاد مفهوم متفقٍ عليه لـهذا المصطلح: "غسيل الأموال" بسبب تعلُّد مصادر الأموال غير المشروعة، وتنوُّع طرق ووسائل الغسيل، وتبايُن وجهات النظر حول المصادر التي يجب أن تكون هدف التجريم في إطار المكافحة، وذلك بحسب ما عرض له القانونيون المعاصرون

في كتبهم عند التناول لهذا الموضوع (1).

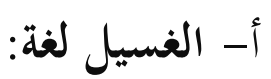

قال ابن منظور: "غسل الشيء يغسله غسلا وغسلا، وقيل: الغسل المصدر

من غسلت، والغسل، بالضم، الاسم من الاغتسال، يقال: غسل وغسل "(؟ "). وغسلته غسلا من باب ضرب، والاسم الغسل بالضم وجمعه أغسال مثل:

قفل وأقفال، وبعضهم يجعل المضموم والمفتوح بمعنى واحد وعزاه إلى سيبويه، وقيل:

(1) انظر: غسيل الأموال الظاهرة الأسباب العلاج، د// محسن أحمد الخضيري، نشر بحموعة النيل العربية،

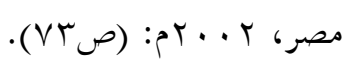

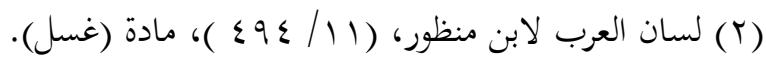


الغسل بالضم هو الماء الذي يتطهر به، والغسل تمام الطهارة، وهو اسم من الاغتسال، وغسل ثوبه: نظفه بالماء، وأزال وسخه وجعله نظيفا، والمغتسل: الموضع الذي يغتسل فيه، وتصغيره مغيسل، والجمع المغاسل والمغاسيل، وغسل الله ذنبه: طهره منه، وغسل الله حوبته: طهره من إثمه غسل الإهانة- غسل العار: محاه، تخلص منه (1)

وقد ورد الغسل في القرآن الكريم ثلاث مرات قال - تعالى - في صفة

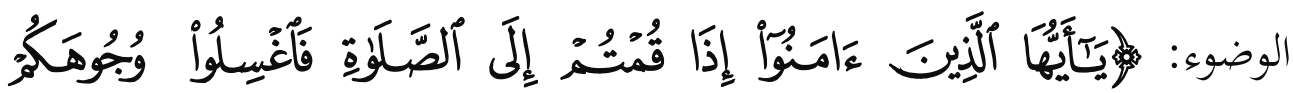

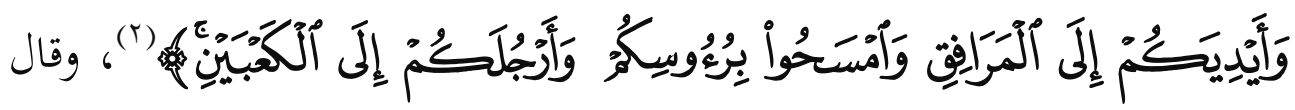

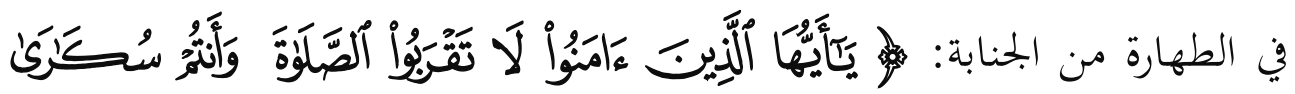

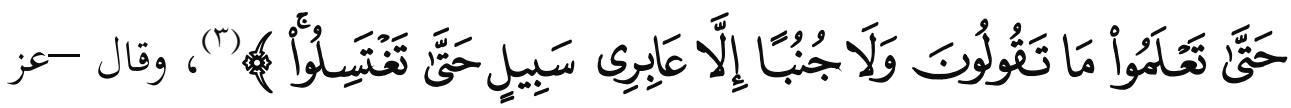

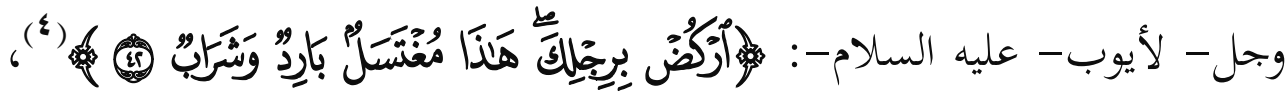
فكلمة "غسل" مصدر يدل على النظافة والطهارة(•). ب-الغسيل في الاصطلاجح:

تطلق هذه اللفظة بحسب موقعها العلمي فعلماء النفس يقولون غسيل المخ، وعلماء الأحياء والطب يقولون غسيل المعدة وغسيل الكلى، وعلماء القانون

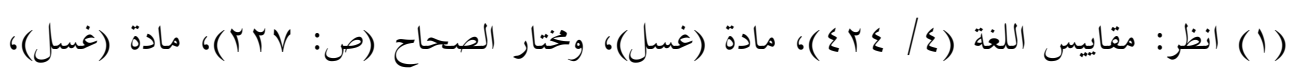

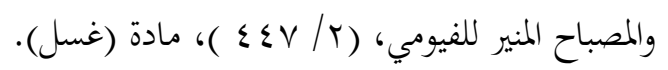

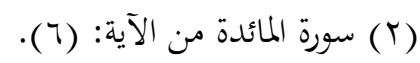

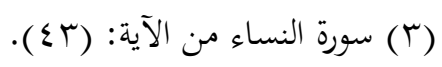

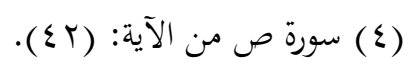

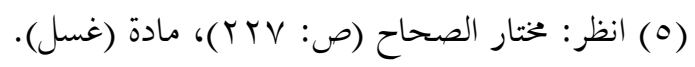


والاقتصاد يقولون غسيل الأموال، وهكذا فمصطلح (غسيل) دلالته بحسب موقعه في سياق الكلام، لكنه يراد منه عموما: تغيير الشيء عن صورته الأولى إلى الى

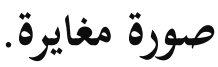

\section{غسيل الأموال اصطلاحا عند علماء القانون والاقتصاد:}

يُعرف فقهاء القانون وعلماء الاقتصاد "غسيل الأموال" بأنه: "بحموعةٌ من الئ المراحل العملية والمراحل التنفيذية المتتابعة التي تقوم بها عصابات الجريمة المنظمة

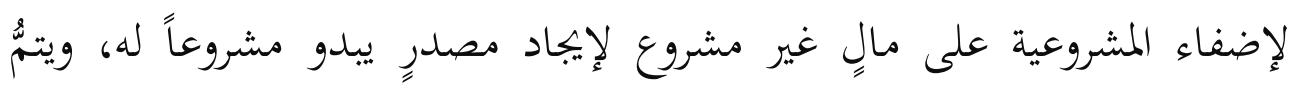

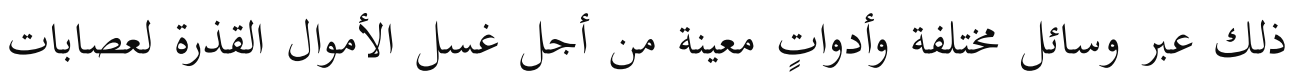
الجريمة التي اكتسبتها من ممارسة الجرائم السابقة على عملية الغسيل ومن ثم تحتاج إلى غسله وإدخال هذا المال في قنوات بنكية وغير بنكية لإبعاد شبهة الجريمة عنه وإظهاره على أنه مال شريف طاهر" (1) . ن. وقيل هو: "جريمةٌ دولية منظمة، يقوم بمقتضاها أحد الأشخاص بإجراء سلسلةٍ من العمليات المالية المتلاحِقة على أموالٍ غير مشروعة تنتُج عن أنشطةٍ

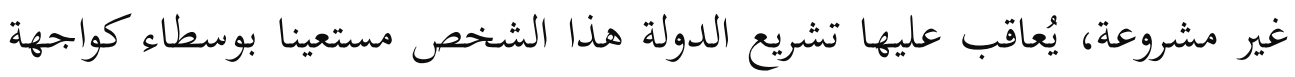

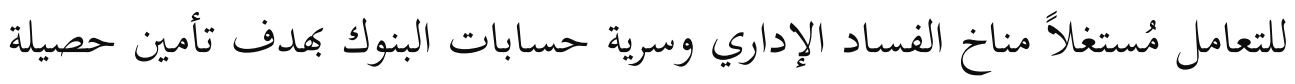
أموالها القذرة من المملاحَقة الرقابية والأمنية "(؟). وهذا يعني أن غسيل الأموال هو: الحصول على أموال أو استثمارات غيه وليه

(1) انظر: غسيل الأموال الظاهرة الأسباب العلاج، د/ حمسن أممد الخضيري، نشر بمموعة النيل العربية،

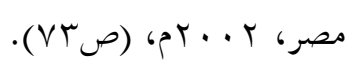

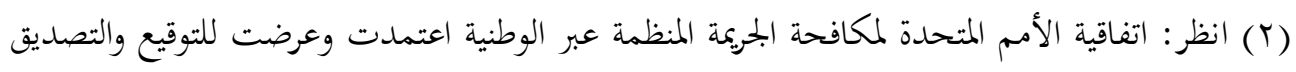

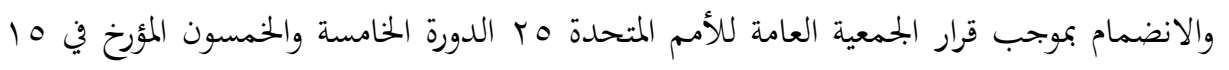

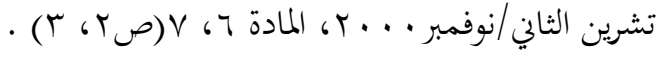

$$
\begin{aligned}
& -1 \Lambda_{-}
\end{aligned}
$$


شرعية من خلال طرف خارجي لإخفاء المصدر الحقيقي لما، وبعبارة أخرى هو عملية تنظيف الأموال من مصدرها البحرم وجعلها قانونية. "وجهة البحث في مصطلح "غسيل الأموال" :

بناء على ما تقدم فالأصح في اللغة: ألا تسمى هذه العملية بغسيل الأموال، بل التسمية الأدق لها هي: "تمويه مصدر الأموال"؛ لأن الغسيل يكون بمعنى التطهير، والمراد هو: "التمويه" لا حقيقة التطهير بحيث يبدو المال كأنه مكتسب من طرق مشروعة فلا يبرم صاحبه ولا يقع تحت طائلة القانون؛ فالعبرة

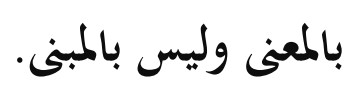
عزمسل الأموال في الشرع

مصطلح غسل الأموال يعتبر من المصطلحات المعاصرة التي لم يعرفها فقهاء الشريعة الإسلامية في مؤلفاقهم قديما. وعلى الرُغم من أن هذا الاصطلاح حديث لم يألفه فقهاء الشريعة الإسلامية قديما فلم يبلوروه في تصانيفهم على شكل المفاهيم الحقوقية المعاصرة إلا أن الأحكام الفقهية التي جاءوا بها تقطع بوجود تصور في أذهاهم لهذه الظاهرة. وعلى سبيل المثال بند أن الإمام أبا الفرج ابن الجوزي كان من الأوائل الذين تنبهوا إلى مسلك أصحاب غسيل الأموال في زمنه حين قال: " رأيت بعض المتقدمين سئل عمن يكتسب حلاًا وحرامًا من السلاطين والأمراء، ثم يبني المساجد والأربطة: هل له فيها ثواب؟ فأفتى بما يوجب طيب قلب المنفق، وأن له في إنفاق ما لا يملكه نوع سمسرة؛ لأنه لا يعرف أعيان المغصوبين فيردها عليهم! فقلت: وا عجبًا من المتصدين للفتوى الذين لا يعرفون أصول 


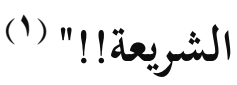

وواضح من كلامه - رحمه الله-أنه كان يعني فئة تلطخت أيديها بالمال الحرام، ثم غرَّر بهم بعض المفتين الجهَّال بجواز غسل أموالهم ببنائهم المساجد والأربطة، وبالتالي يزول عنهم العنت والإثم وكأنَّ شيئا لم يحدث . وقد عرفه بعض أساتذة الشريعة المعاصرين - منهم أ.د. عطية فياض - بأنه: "تصرفات مالية مشروعة لمال اكتسب بطريقة غير مشروعة بغرض إخفاء (؟)" مصدره قخاصة وجهة البحث في "مصطلح غسيل الأموال" : البحث يرى رجحان هذا النظر للفقهاء المعاصرين: أن مصطلح غسيل الأموال غير دقيق ويراد به باطل، وأنه لا يعني الغسل الشرعي الصحيح والواجب: أن يتطهر صاحب المال المكتسب من طرق غير مشروعة من هذا المال بإنفاقه في العمل الخيري إذا لم يعلم مالكه ولم يمكن رده، بل يعني جريمة مركبة من عدة جرائم لا تمت إلى الغسل بصلة بل تقوم على قذارة واضحة كما أشار إلى ذلك القانونيون المعاصرون في كتبهم على نخو ما سبق أن عرض له. والذي يهمنا ـ هنا في هذا البحث ـ ليس التعرض إلى تحديد مصطلح "غسيل الأموال" والخالاف في ذلك بين المعاصرين قانونيين وفقهاء بقدر ما يهمنا بيان الحكم الشرعي فيما لو تاب مكتسب هذا المال من غير الطرق المشروعة وأراد أن يتطهر منه: فهل يجوز له صرفه في الأعمال الحيرية؟ وما

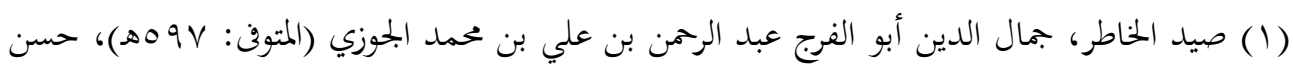

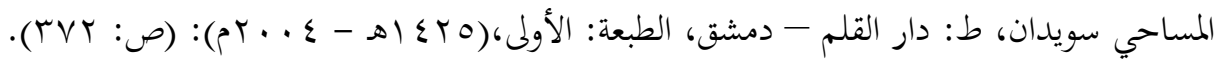

$$
\begin{aligned}
& \text { Yريمة غسل الأموال في الفقه الإسلامي، د. عطية فياض (ص r Y T). } \\
& -r \cdot-
\end{aligned}
$$


الضوابط الشرعية التي تراعى في قبول هذا المال؟ وما الجمالات التي يصرف

\section{ثانيا: تعريف الأموال الحرام. \\ (أ) تعريف المال لغة واصطلاحا.}

المال لغة: أصل مادته (مول)، وجمعه (أموال)، ويقال: تمول الرجل. أي:

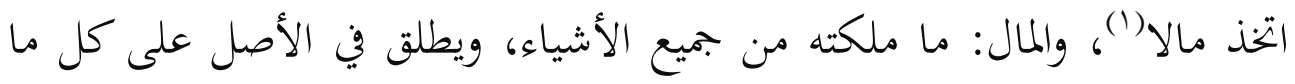

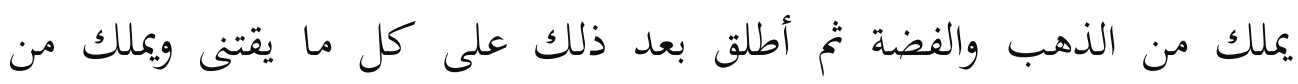
الأعيان، وأكثر ما يطلق المال عند العرب على الإبل؛ لأهما كانت أكثر أموالهم،

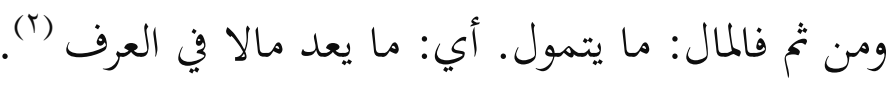

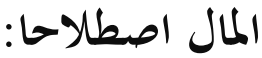

اختلف الفقهاء في تعريف المال اصطلاحا وذلك على النحو التالي:

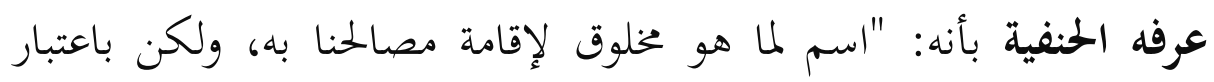
صفة التمول والإحراز"(").

ومن ثم فإن تعريف المال عند الحنفية عبارة عما اشتمل على صفة التمول،

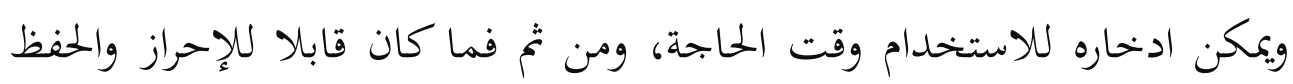

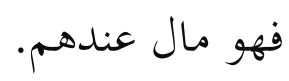

(1) انظر: لسان العرب، (11/ דrآ)، مادة (مول).

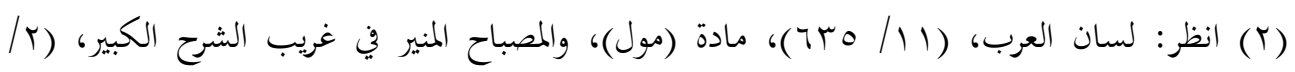

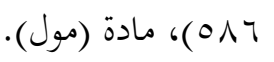

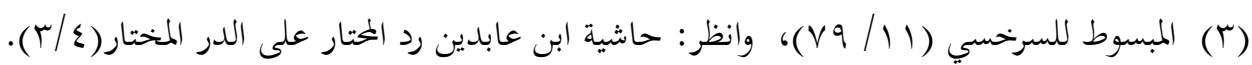


وعرفه المالكية بأنه: "ما يتمول في العادة ويجوز أخذ العوض عنه"((). ونلاحظ-هنا-: أن تعريف المال عند المالكية موافق لتعريف المال في اللغة عموما، وهو ما يمكن أن يتملك، فكل ما ملكه الإنسان واستبد به - كما قال الشاطبي-فإنه يعتبر مالا عندهم.

وعرف الشافعية المال بأنه: ما كان منتفعا به. أي: ما كان مستعدا لأن ينتفع به (r)

وإذا تأملنا تعريف المال عند الشافعية بجده يشمل كل ما له قيمة ويضمن، ويشمل ذلك كل ذا قيمة يجصلها الناس حتى لو كانت منفعة وليست مالا عينيا. وعرفه الحنابلة بأنه: ما يباح نفعه مطلقا. أي: في كل الأحوال، أو هو ما يباح اقتناؤه بلا حاجة (َ) فتعريف المال عند الحنابلة يشمل كل ما فيه منفعة مباحة، ومن ثم فما فيه منفعة فهو مال عندهم وما لا منفعة فيه أو كانت المنفعة فيه للحاجة والضرورة فليس مالا عندهم.

\section{: اختلاوف الفقهاء في اعتبار المنافع مالا :}

ومن خلال تأمل هذه التعريفات : بجد أن الفقهاء اختلفوا على قولين في

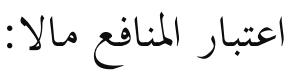

(1) الإشراف على مسائل الخلاف للقاضي عبد الوهاب (r / T / (T)، وعرفه الشاطبي بقوله: "ما يقع

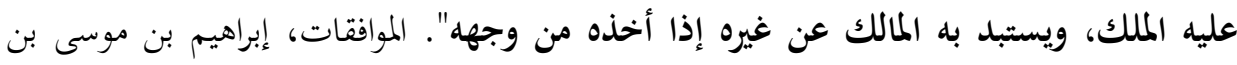

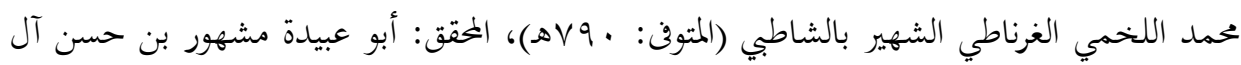

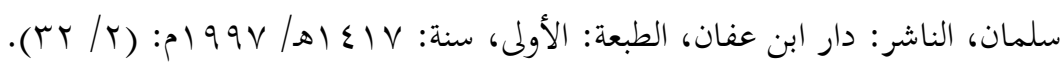

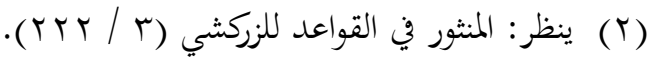

$$
\begin{aligned}
& \text { (r) ينظر: شرح منتهى الإرادات (T/Y \& ( ). }
\end{aligned}
$$


القول الأول: قول جمهور الفقهاء من المالكية(')، والشافعية(r)، والحنابلة(r) حيث يعتبرون المنافع - كسكنى الدار ولبس الثوب وركوب الدابة- أموالا بذاقا. واستدلوا على ذلك بأدلة؛ منها ما يلي:

ا - إن الأعيان لا تقصد لذاتا، بل للمنافع التي فيها، وعلى هذا جرت أعراف الناس ومعاملاكمه، ومن ثم فإها تعد مالا. r- إن الشرع قد حكم بكون المنفعة مالا عندما جعلها مقابلة بالمال كما في عقد الإجارة، وهو من عقود المعاوضات المالية (ع). القول الثالي: قول الحنفية وهو أن المنافع والحقوق ليست أموالا متقومة في حد ذاتما إلا إذا ورد عليها عقد معاوضة، كما في الإجارة، وذلك على خلاف القياس، وما كان كذلك فلا يقاس عليه غيره(0). ووجهتهم في ذلك: أن صفة المالية للشيء تثبت بالتمول، والتمول هو صيانة الشيء وادخاره لوقت الحاجة، والمنافع لا تبقى زمانين؛ لكوها أعراضا، ومن تم فلا يتصور فيها التمول (7).

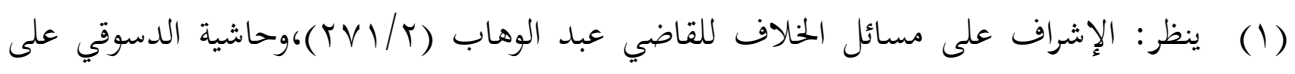

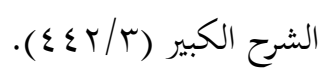

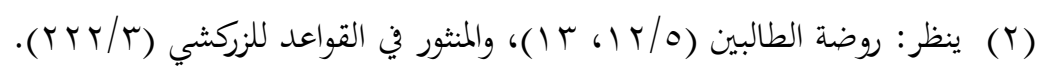

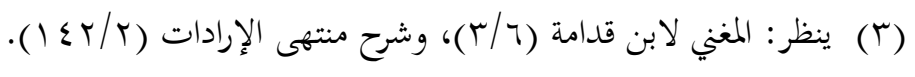

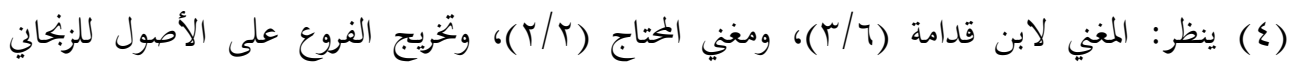

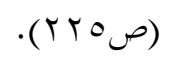

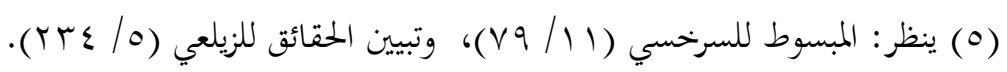

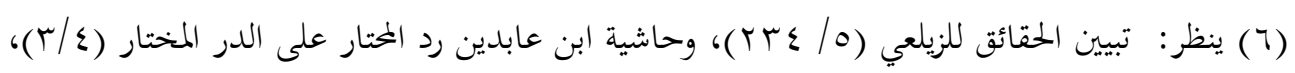

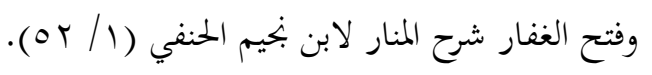

$$
\begin{aligned}
& \text { - }
\end{aligned}
$$


والراجح من القولين: قول جمهور الفقهاء باعتبار المنافع والحقوق مالا؛ لأن هذا هو الموافق لمقصود الشرع والعرف، فما يعد في العرف مالا فهو مال؛ ولأن في تعني

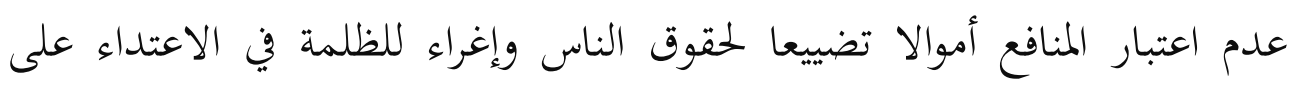

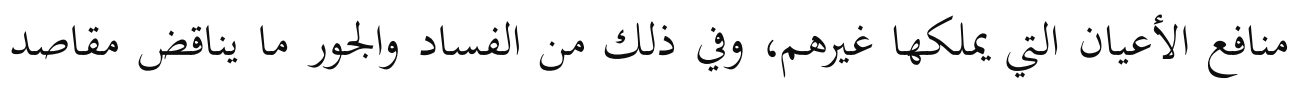
الشريعة الغراء.

ومن ثم فإن المقصود بالمال في هذا البحث: ما يعنيه تعريف المال عند

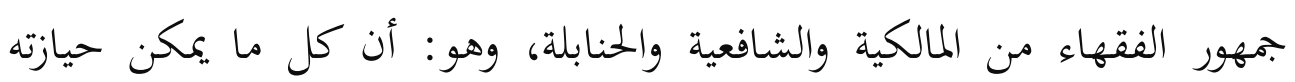

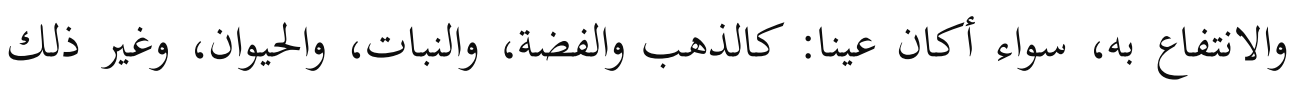

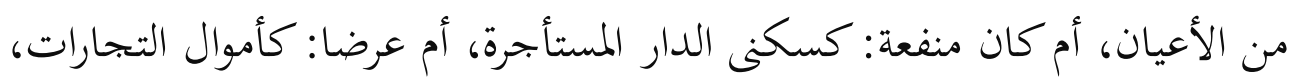

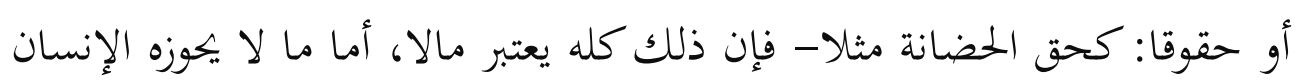

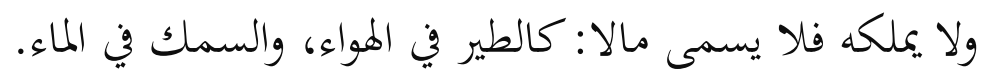
(ب)تعريف الحرام لغة واصطلاحا.

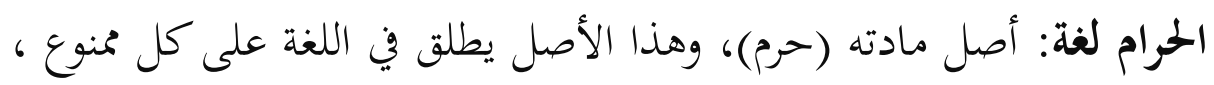

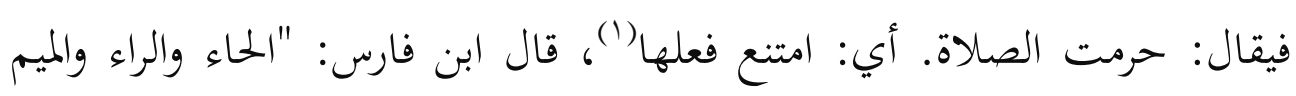

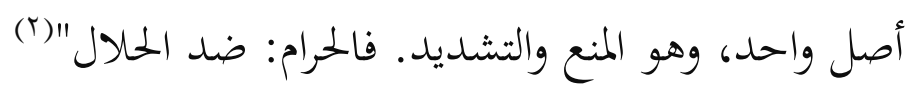

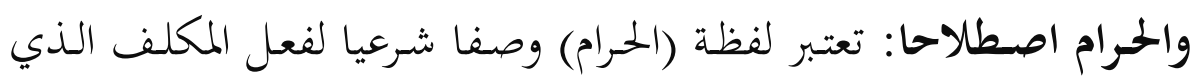
فهى عنه الشرع غيا جازما ، وتوعد فاعله بالعذاب في الآخرة، والعقوبة في الدنيا

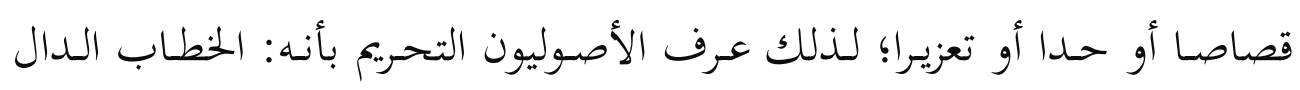

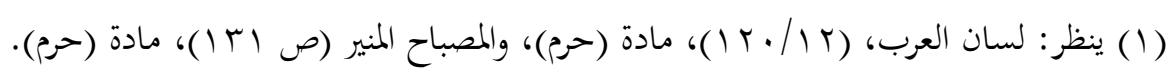
(ז) مقاييس اللغة (r/ (1))، مادة (حرم). 


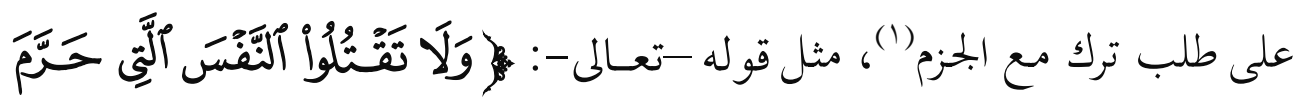

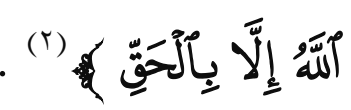

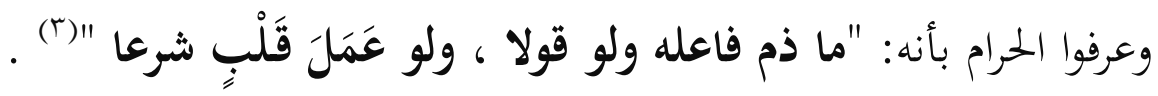

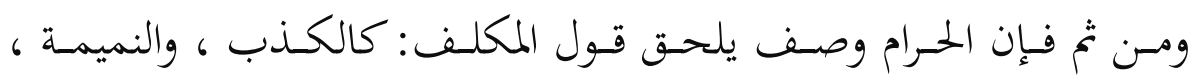

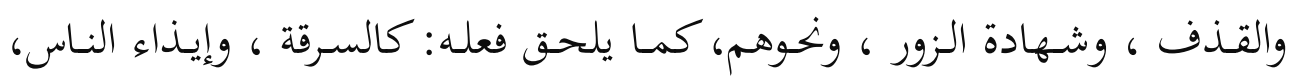
كما يلحق عمل القلب كذلك: كالكبر والرياء ونهوهما.

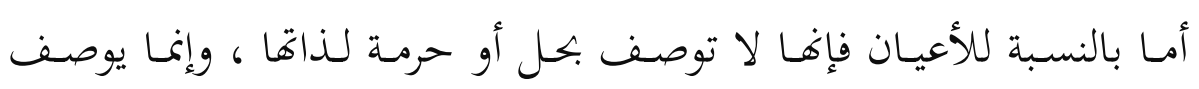

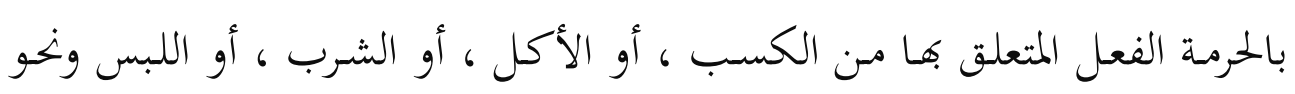
ذلك.

ومن ثم يقال: مال حرام. أي: مال مكتسب من طريق محرم وهو ما يطلق

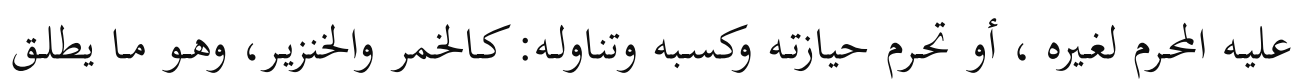

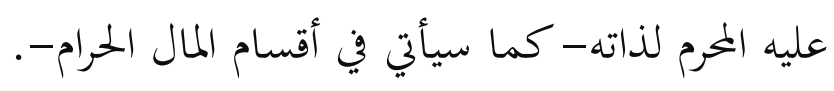
(ج) تعريف المال الحرام اصطلاحا. المال الحرام هو: المال الذي حظره الشرع لصفة في عينه أو من جهة كسبه،

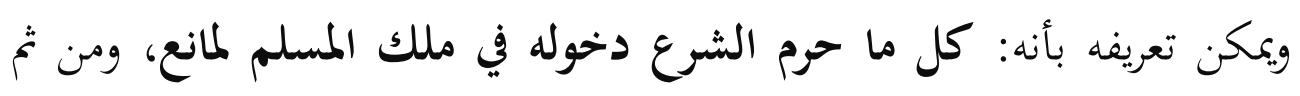

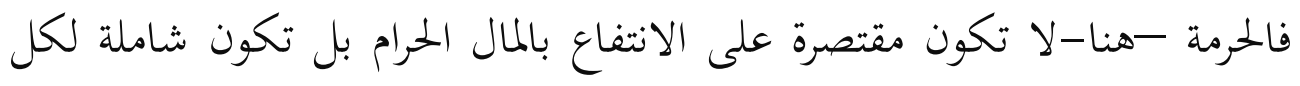

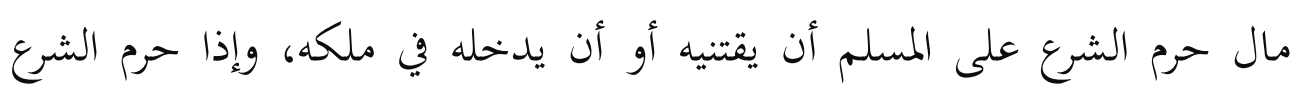

$$
\begin{aligned}
& \text { (1) انظر: شرح غختصر الروضة للطوفي (1// (بTr). } \\
& \text { (Y) سورة الأنعام من الآية: (101) (101). }
\end{aligned}
$$

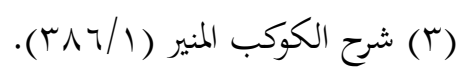


دخول مثل هذا المال في ملك المسلم فمن باب أولى يكرم عليه الانتفاع به؛ لأن

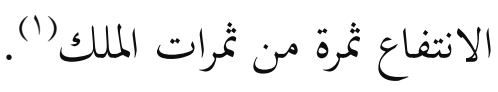
المطلب الثاني

\section{التعريف بالعمل الحيري}

العمل لغة: أصل مادته (عمل)، وهذا الأصل يدل في اللغة على الصنع

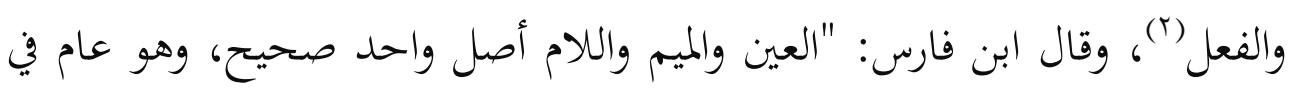

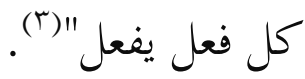
الحيري لغة: نسبة للخير، والخير: اسم تفضيل على غير قياس، وأصل مادته

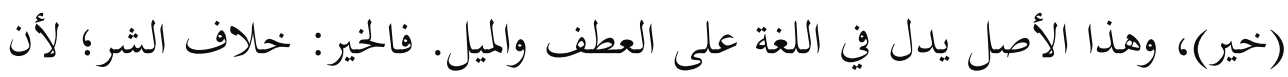
كل أحد يميل إليه ويعطف على صاحبه، وقيل: الخير: الجود والكرم، وقيل هو:

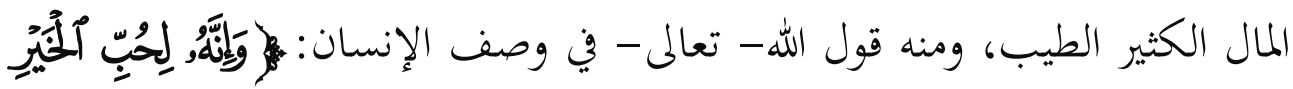

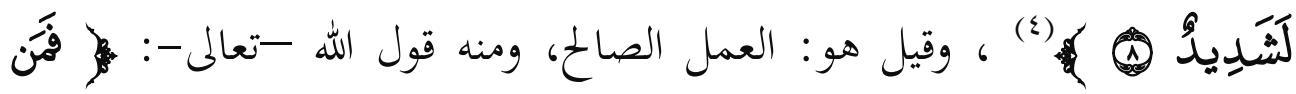

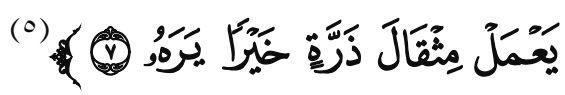

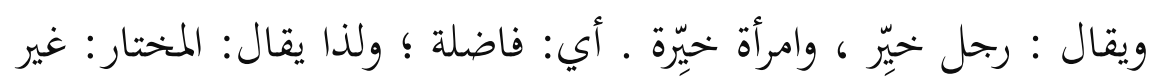

(1) ينظر: أحكام المال الحرام وضوابط الانتفاع والتصرف به في الفقه الإسلامي ، د ـ عباس أحمد الباز ،

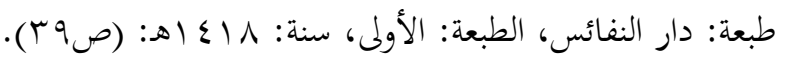

$$
\begin{aligned}
& \text { (T) ينظر : المصباح المنير (صTrآ ())، مادة (عمل). }
\end{aligned}
$$

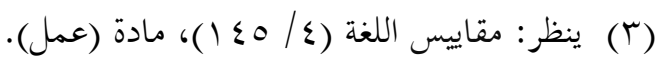

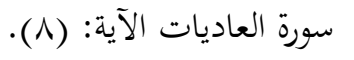

$$
\begin{aligned}
& \text { سورة الزلزلة الآية: (V). }
\end{aligned}
$$


المكره(1)؛ لأنه هو الذي يقدم على فعله من دافع نفسه وليس مرغما من قبل أحد، وهذا المعنى هو المقصود في تعريف العمل الخيري في هذا البحث؛ إذ إن القائم بالعمل الخيري يقدم عليه بنفسه تطوعا منه غير مكره على فعله، وهذا ما سأبينه في الفقرات التالية.

أما العمل الحخيري كمصطلح فإنه لم يرد في كتب الفقه بهذا اللفظ لكن الموجود معناه دون لفظه، فكل عمل يجلب منفعة للمسلمين خاصة كانت أو عامة، ويمنع عنهم مفسدة خاصة كانت أو عامة، سواء أكان هذا العمل فرضا أو سنة أو مندوبا إليه أو مباحا مصحوبا بنية، فهو عمل خحيري.

وقد عرفه بعض المعاصرين بأنه: "النشاط الاجتماعي والاقتصادي الذي يقوم به الأفراد أو الممثلون في الهيئات والمؤسسات والتجمعات الأهلية ذات النفع العام، بهدف التقليل من حجم المشكالات، والإسهام في حلها بالمال أو بالجهد أو

بالفكر "(r) ( بكام

وقريب من مصطلح (العمل الحخيري) مصطلح (العمل التطوعي) وهذا قد عرفه بعض المعاصرين بأنه: " تقلديم يد العون إلى فرد أو بحموعة أفراد هم بحاجة

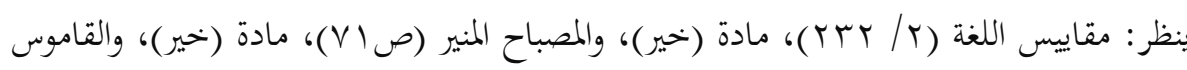

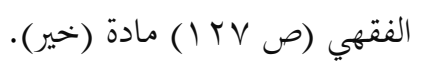

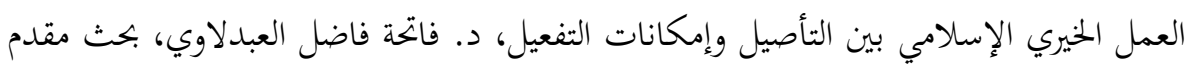

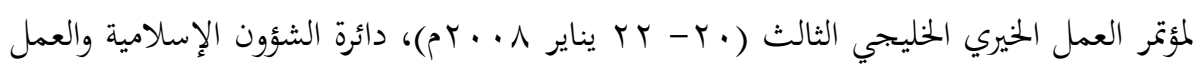

$$
\text { الخيري بدبي: (صهم). }
$$


إليه دون أي مقابل، سواء أكان مادياً أو معنوياً، والغرض منه ابتغاء مرضاة اللهتعالى -" (1)

\section{تعقيب على تعريف العمل الخيري:}

أولا: ذكرت صاحبة التعريف الأول (السابق) أنه (النشاط الاجتماعي والاقتصادي...)، والأفضل من ذلك أن نقول: إنه (تعاون يقوم به أفراد المجتمع المسلم...)؛ لأن لفظة تعاون لفظة قرآنية، وهي تدل في المقام الأول على المطلوب، أما كلمة نشاط فلا تؤدي المعنى الذي تؤديه لفظة (تعاون)؛ لأن النشاط يفهم منه أنه من قبيل الترفيه أو الشيء الزائد الذي يقوم به المرء إذا وجد وقتا له، وإن لم يجد وقتا فلا حاجة له به، هذا في حين أن العمل الخيري قد يكون واجبا أحيانا، وقد يكون مستحبا أحيانا أخرى، بحسب الواقع والواقعة والزمان والمكان. ثانيا: قصرت العمل الخيري على (النشاط الاجتماعي والاقتصادي) والأولى من ذلك عدم قصر العمل الخيري على ذلك، فهو يشمل كل جوانب الحياة المتعلقة بحياة الإنسان، وكذلك يشمل جوانب كثيرة متعلقة بغير الإنسان من حيوانات، ونباتات، وجمادات . ومن ثم يمكن أن نقول: إن عمل الخير ليس مقتصرا على فئة معينة أو بحال معين بل هو مطلق لما فيه نفع البحتمع المسلم وأفراده وفق ضوابط حددتا الشريعة الإسلامية، كما أن العمل الخيري صفة ملازمة لخيرية هذه الأمة قال -تعالى - :

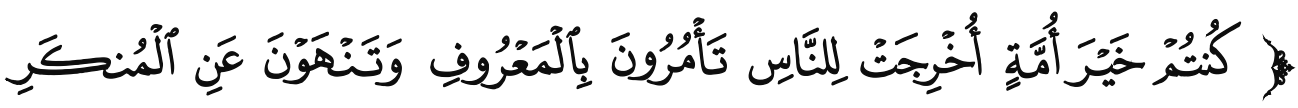

(1) العمل التطوعي في السنة النبوية: دراسة موضوعية، الباحثة: رندا محمد زينو، وهو بحث تكميلي

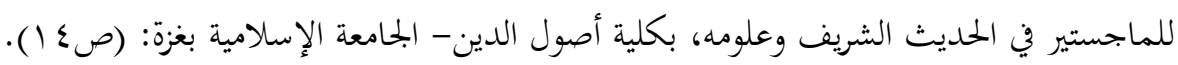




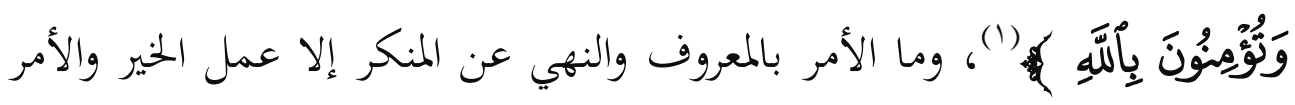
به، والانتهاء عن عمل السوء والنهي عنه، وقد أمر الله - تعالى - عباده المؤمنين

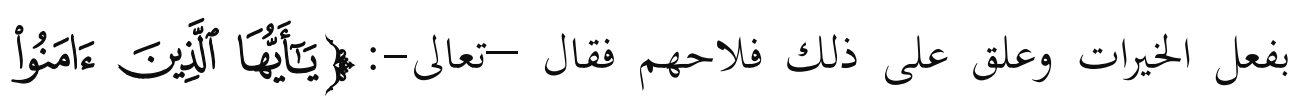

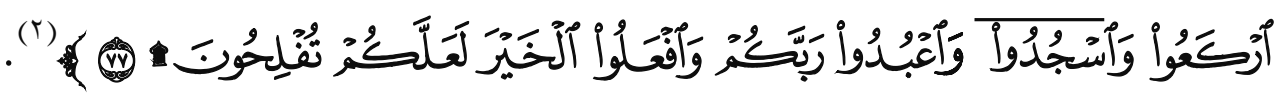

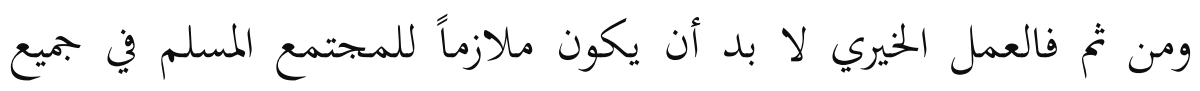

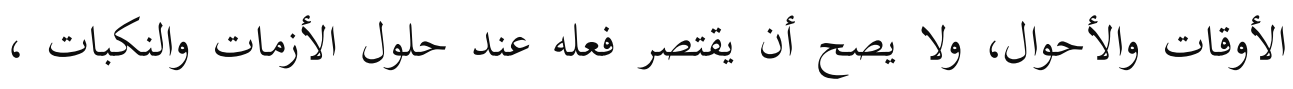

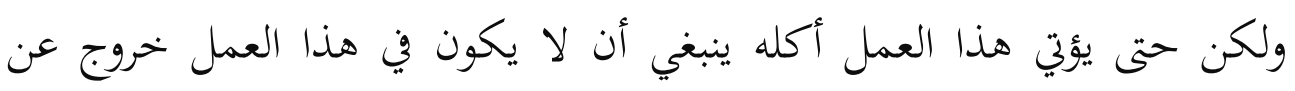

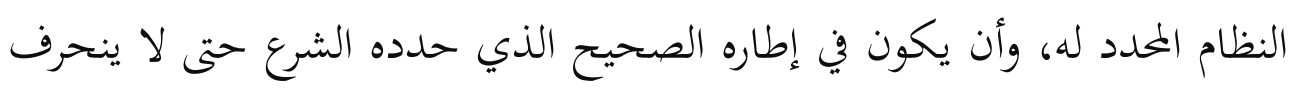

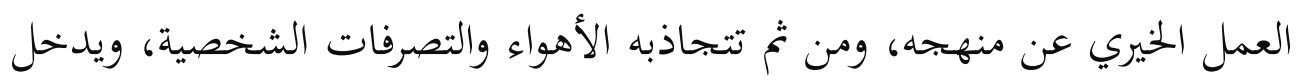

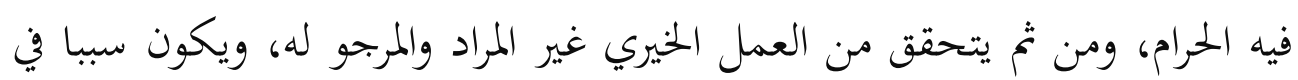
جلب الفساد من حيث أردنا منه الإصلاح.

$$
\begin{aligned}
& \text { (1) سورة آل عمران من الآية: (11). }
\end{aligned}
$$

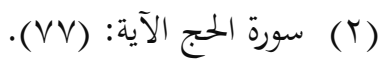


المطلب الثالث

تعريف الحكم والضوابط لغة واصطلاحا

أولا: تعريف الحكم لغة واصطلاححا.

الحكم لغة: أصل مادته (حكم)، وهذا الأصل يدل في اللغة على المنع؛ ومنه:

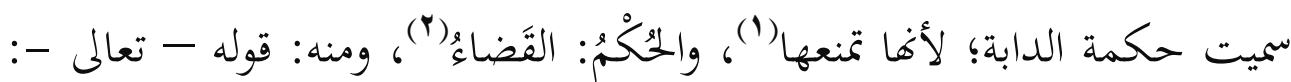

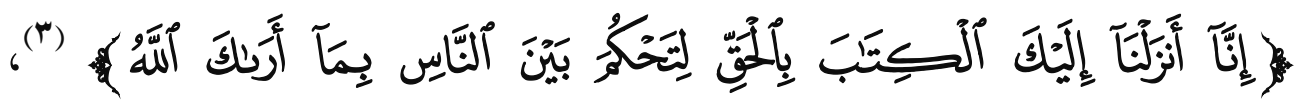

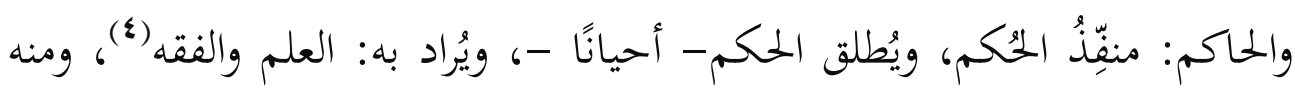

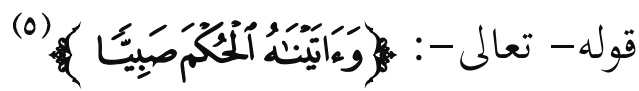

$$
\begin{aligned}
& \text { الحكم اصطلاحا: }
\end{aligned}
$$$$
\text { الحكم في الاصطلاح العام هو: إثبات أمر لأمر أو نفيه عنه(") . }
$$

أما عند الفقهاء والأصوليين، فإهم قد اختلفوا في تعريفهم للحكم - بحسب بحال تناول كل فن له- والسبب في هذا الاختلاف: أن الأصوليين يعرفونه بما يفيد أنه

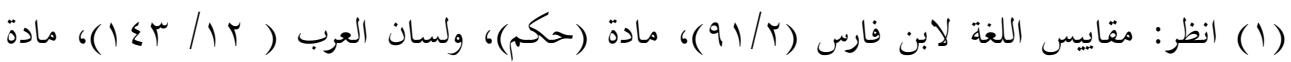

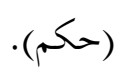

$$
\begin{aligned}
& \text { انظر : المصباح المنير (1 / ع 1 )، مادة (حكم). }
\end{aligned}
$$

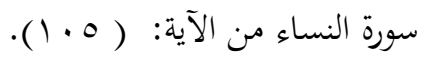

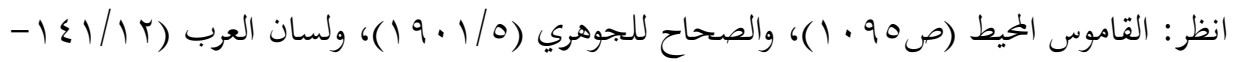

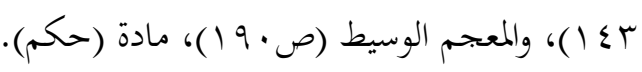

$$
\begin{aligned}
& \text { سورة مريم من الآية: (Y (I) (1). }
\end{aligned}
$$

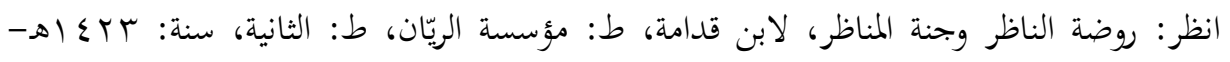

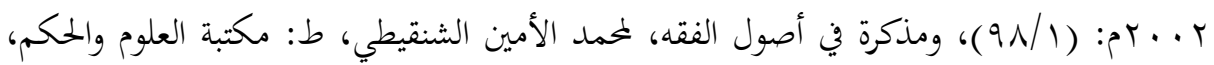

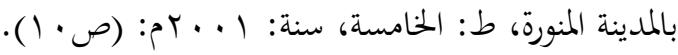

$$
\begin{aligned}
& \text { - r. - n }
\end{aligned}
$$


خطاب الشارع الذي يبين صفة الفعل الصادر من المكلف، والفقهاء يعرفونه بما يفيد أنه أثر ذلك الخطاب( (1). فالحكم عند الفقهاء: ما ثبت بالخطاب: كالوجوب، والحرمة.أي: صفة فعل

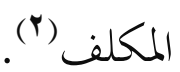
وعرفه جمهور الأصوليين بأنه: "خطاب الله - تعالى - المتعلق بأفعال المكلفين

$$
\text { بالاقتضاء أو التخيير أو الوضع "(؟). }
$$

\section{ثانيا: تعريف الضوابط لغة واصطلاححا.}

الضوابط لغة: مفردها (الضابط)، وأصل مادتا (ضبط)، وهذا الأصل يدل في اللغة على عدَّة معانٍ؛ منها: - الحفظ والحزم، فيقال: رجل ضابط. أي: حازم، وضبطُ الشيء. أي: حفظُهُ بالحزم (乏) - الحبس والقهر، ولزوم الشيء وإتقانه، فيقال: اضبط الشيءَ. أي: الزمه ولا تفارقه، وضبط الرجلُ الشيءَ يضبطه ضبطًا: إذا أخذه أخذًا شديلًا. وأرض

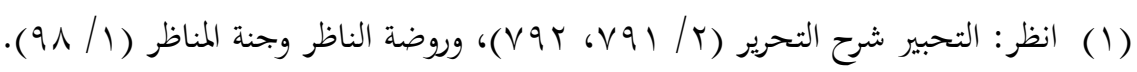

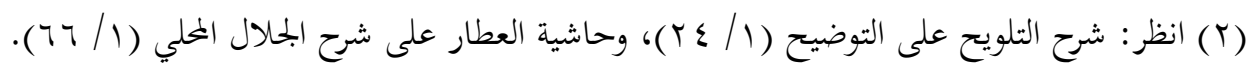

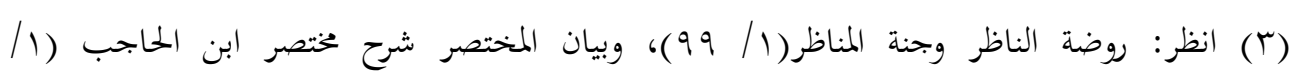

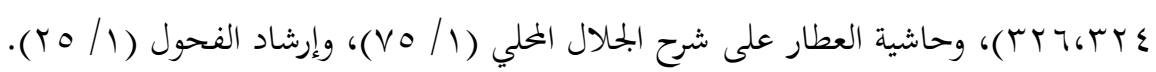

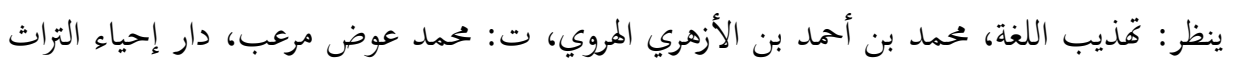

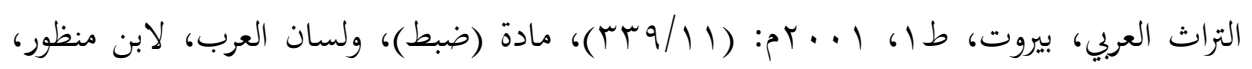

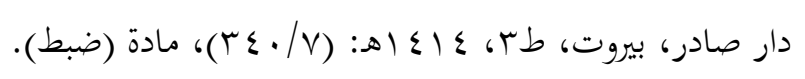


مضبوطة: عمَّها المطر (1)، ويقال: رجل أضبط، وهو: الذي يعمل بيديه جميعًا(؟). ومن ثم فإن أغلب المعاني للضبط تدور حول الحفظ والحزم، والحبس والقهر، واللزوم، وضبط العمل وإحسانه، والضابط اسم فاعل مشتق من ضبط الشيء إذا لزمه وحبسه، وهو مأخوذ من الضبط لَّان. وهذه المعاني هي المقصودة في هذا البحث؛ حيث أحاول بحتهدا استخلاص بعض الضوابط الشرعية الحاكمة والجامعة لقبول المال المغسول وضوابط إنفاقه في الأعمال الخيرية. الضوابط اصطلاحا. سلك العلماء في تعريف الضابط مسلكين: المسلك الأول: اعتبار الضابط بمعنى القاعدة الفقهية دون تفريق بينهما، فعرفوه بأنه "الأمر الكلي المنطبق على جميع جزئياته، فالقاعدة قضية كلية يدخل تحتها جزئيات كثيرة، وتحيط بالفروع والمسائل من الأبواب المتفرقة"(ع).

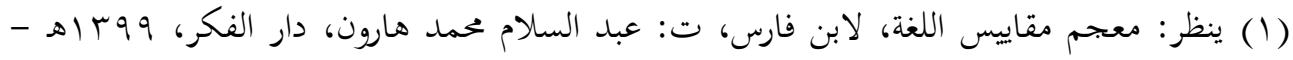

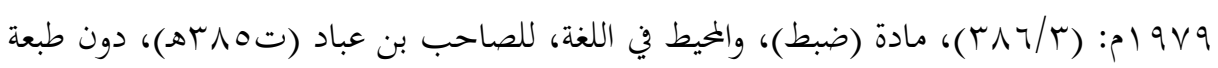

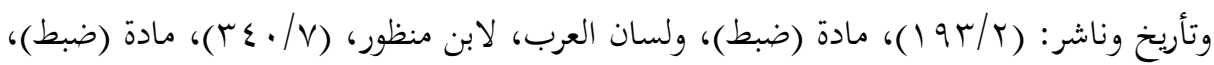

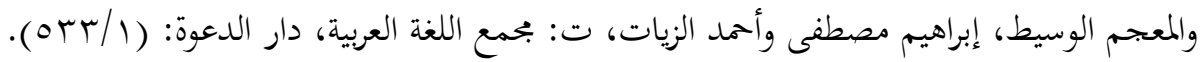

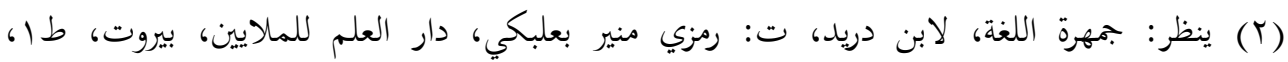

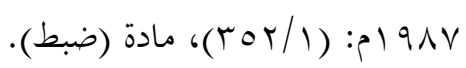

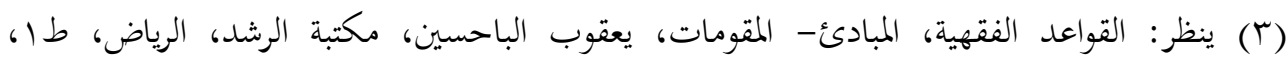
. (ص人) (ص)

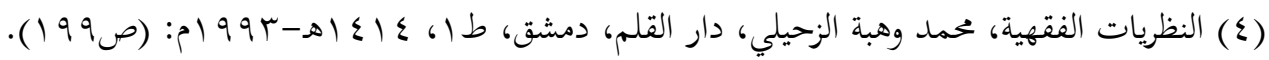


ومن ثم فهما لفظان مترادفان يدلَّان على معنى واحد(')، وعلى هذا كثير من العلماء(r)" وصرح الفيومي(r) بذلك حيث قال: "القاعدة في الاصطالاح بمعنى الضابط، وهي: الأمر الكلي المنطبق على جميع جزئياته"(ع) : المسلك الثاين: اعتبار الضابط غير القاعدة الفقهية، فمجال الضابط

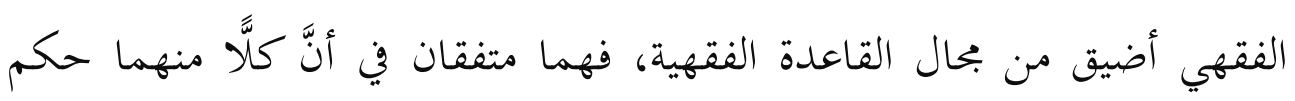
كلي تندرج تحته فروع فقهية، إلا أنَّ الضابط يختص بباب فقهي واحد فتط،

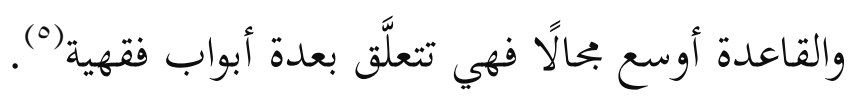

(1) ينظر: القواعد الفقهية، علي أحمد الندوي، دار القلم، دمشق، طس، عـإاهـ - ع 99 ام: $\cdot(0 \cdot-\varepsilon V(ص)$

(T) كالكمال ابن الهمام في التحرير في أصول الفقه الجامع بين اصطلاحي الحنفية والشافعية، مطبعة

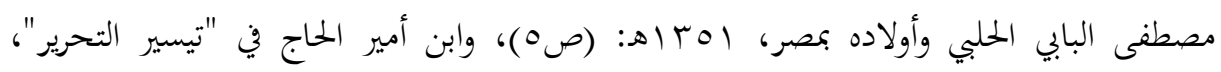

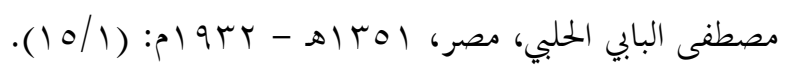

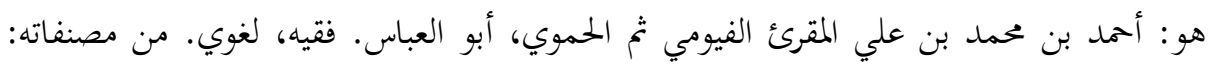

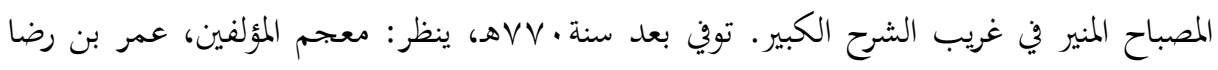

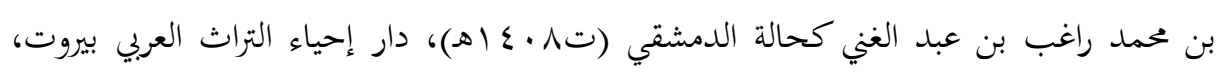

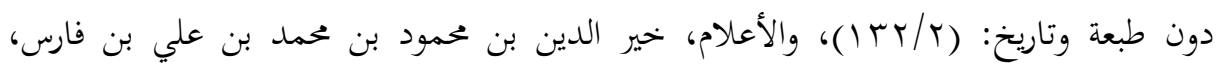

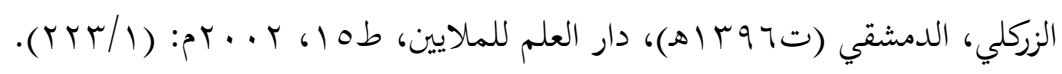

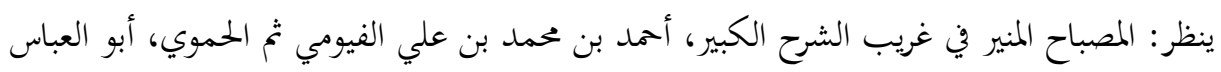

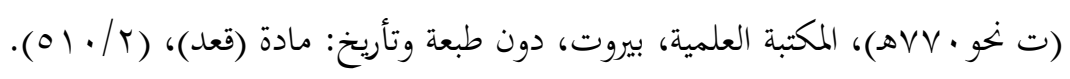

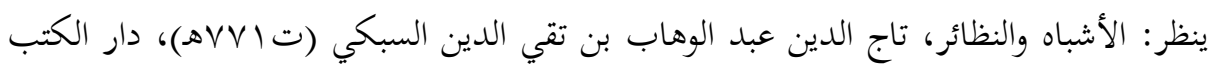

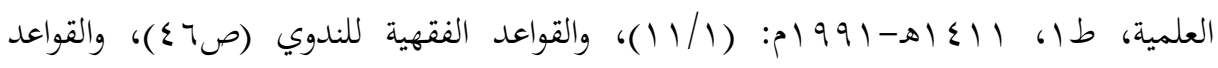

$$
\text { الفقهية، للباحسين (صوهن، طو). }
$$


وصرح ابن بجيم (1) بذلك فقال: "الفرق بين الضابط والقاعدة: أنَّ القاعدة تجمع فروعًا من أبواب شتى، والضابط يجمعها من باب واحد. هذا هو (r)" الأصل

وعلى هذا جرى الاصطلاح عند العلماء المتأخرين على التمييز بين الضابط

الفقهي والقاعدة الفقهية(؟).

ويمكن تعريف الضابط بمعنى أوسع فيحمل على معناه اللغوي، فيكون معناه:

"كل ما يحصر ويجبس، سواء كان بالقضية الكلية، أو بالتعريف، أو بذكر مقياس الشيء، أو بيان أقسامه، أو شروطه، أو أسبابه، وحصرها"(\&).

(1) هو: زين الدين بن إبراهيم بن محمد بن محمد الشهير بابن بخيم الحنفي، من فقهاء الحنفية الكبار،

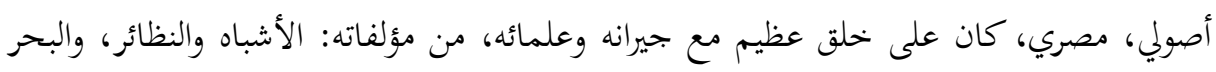

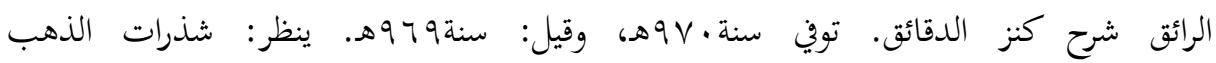

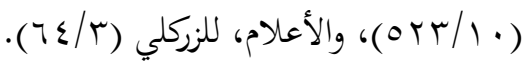

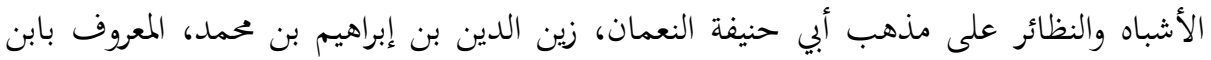

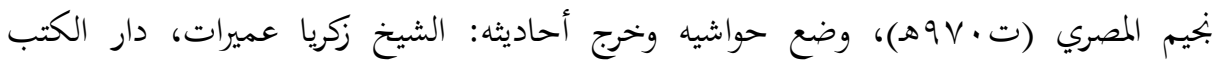

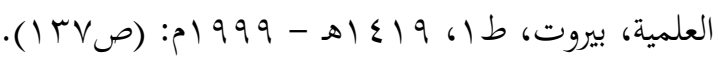

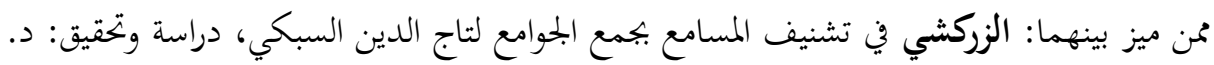

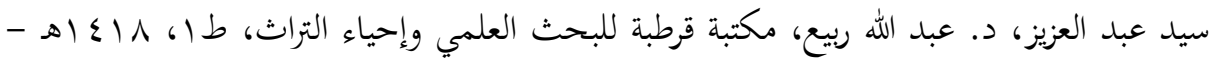

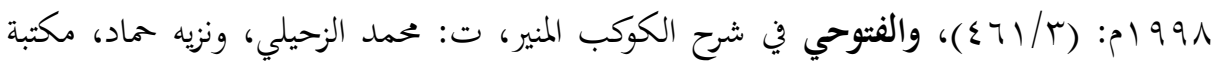

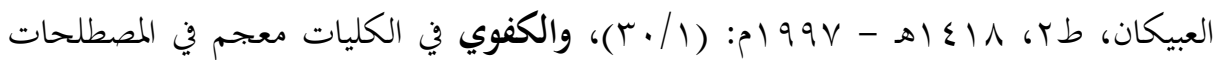

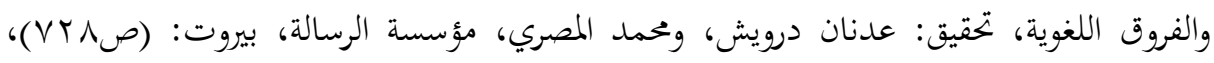

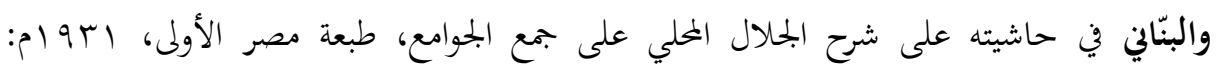

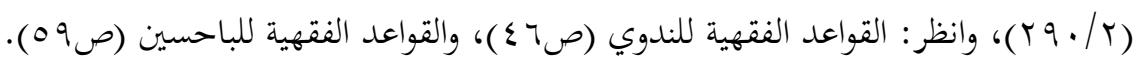
القواعد الفقهية، الباحسين (صד Tك، VV). 


\section{غسيل الأموال الحرام في العمل الغيري}

\section{حكميه وضوإبطا}

د. أحمد علي الحمد موافي أبحاث "يْ2 ضوء نصوص مذاهب الفقه، وأدلته، ومقاصده الكليت"

وهذا التعريف ينسجم مع إطلاقات العلماء على المقصود من الضابط، وهو

الموافق لمعنى الضابط لغة؛ وهذا المعنى هو المقصود في هذا البحث؛ حيث يهدف

البحث إلى بيان الضوابط الشرعية لغسيل الأموال الحرام في العمل الخيري، وذلك بعد التأصيل لهذا الموضوع. 


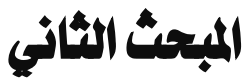 \\ القسام الأل الهرام، وأهم صوره}

ويشمل هذا المبحث مطلبين:

\section{المطلب الأول}

أقسام المال الحرام

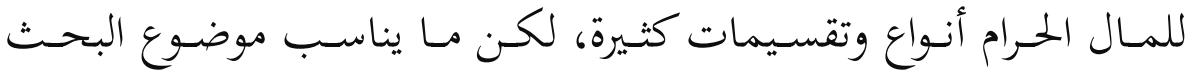
تقسيمه بحسب سبب التحريم ومنشؤه، فبحسب منشأ التحريم والسبب المقتضي له ينقسم المال المرم إلى قسمين: القسم الأول: المال الحرام لذاته

وهو مـاكـان حرامـا في أصله ووصفه، وحرمـه الشـرع لسبب قـائم فيـه، لا لا ينفك عنه بحال من الأحوال، لما اشتمل عليه من خبـث: كالخمر لصفة الإسكار فيها، والنهي عن بيع الأجنـة في بطون أمهاهَا، فإن ذلك محرم لعينه، والكلب، والخنزير فلا يجوز بيع شعر الخنزير؛ لأن الخنزير عينه بنجس بجميع أجزائه فمنع الشرع الانتفاع به إهانة لعينه واستقباحا لذاته (1)، وكذلك الميتة والدم وسائر النجاسات والمستقذرات التي تسبب الأذى للإنسان، فهذه حرام على المسلم في كل حال، سواء أحازهـا المسلم بسبب معتبر أم بغير ذلك، ولا يرفع إتم تناولها إلا للمضطر فقط وبضوابط (r)

(1) ينظر: المحيط البرهاني في الفقه النعماني (T/ . (1) ).

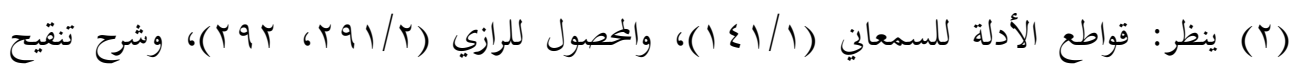

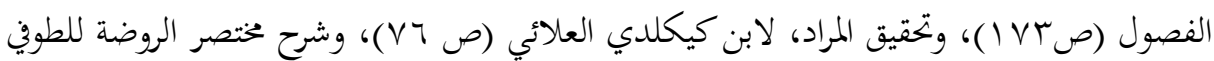
. $(\varepsilon r q / r)$ 
والأمسوال المحرمـة لم يقـف تحريم الإسـلام لهـا عنـد حـدود التنـاول بالأكسل أو الشـرب فقط؛ إنما حرم كافة المنـافع المتعلقـة بهـا، ففي الخمـر مثلال قال رسول الله

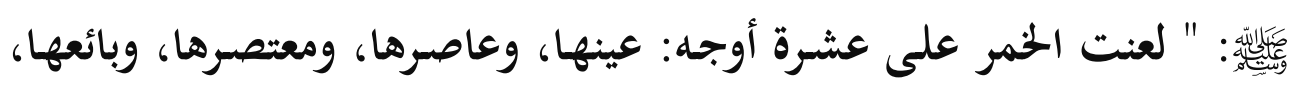
ومبتاعها، وحاملها، والخمولة إليه، و آكل ثثنها، وشـاربها، وسـاقيها "(() ، وي الربا : الآكل، والمعطي، والشاهد، والكاتب، عن جابر بن عبد الله أن رسول الله

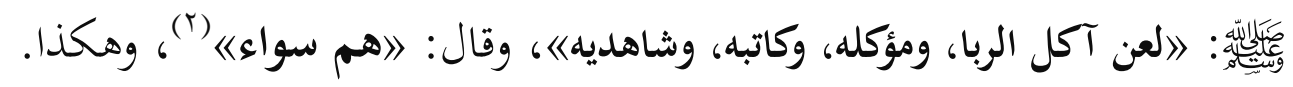
وهذا المال الحرام يقاس عليه كل ما يؤدي إلى إلحاق الضرر بالإنسان، سواء دخل هـذا المـال الحـرام تحـت يـد المسـلم وسبب التحريم فيه قائم ابتـلداء: كالحنزير والميتـة، أو كـان طارئـا عليـه: كمـأكول اللحـم إذا طرأ عليـه المـوت وأصبـح ميتـة، فيقـاس عليـه النجاسـات والمسـتقذرات ومــا هـو في معناهـا: كالمخهــرات وأنـواع الدخان التي تلحق الأذى المحقق، وتسبب الأمراض للإنسـان، ويحصل بهـا الضرر المقطوع بـه، وهـذا القسم - المـال الحـرام لذاتـه - ليس داخـالا معنـا في هـذا البحث؛ لأنه ليس عحلا للانتفاع.

(1) سنن ابن ماجة (Y/ / / / (I)، كتاب: الأشربة، باب: لعنت الخمر على عشرة أوجه، برقم

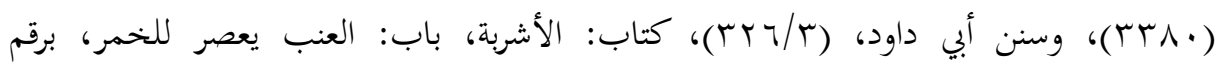

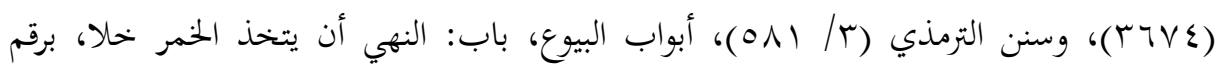

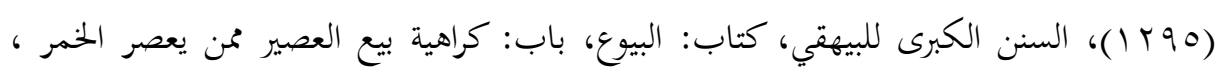

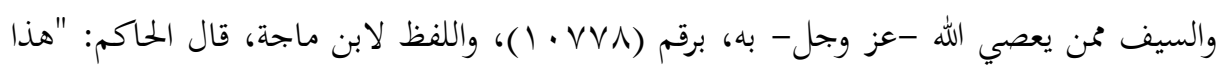

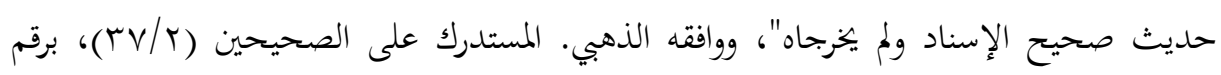

(Y) أخرجه مسلم في صحيحه ، كتاب: المساقاة، باب: لعن آكل الربا ومؤكله، برقم (1091) ). - rv_ 


\section{القسم الثالي: المال الحرام لغيره}

وهو مـا كان مشروعًا في أصله، ولكن اقترن بـه أمر آخر يسبب مفسـدة وضررا للناس، فحرمه الشارع لهذا السبب(1): كالمال المباح المسروق، فالمال في ذاته مباح ، لكن يكرم الانتفاع به بسبب حرمة كسبه، والمغصوب ، والمختلس من المال العام ، والمأخوذ بالغش والخداع ، والرشوة التي يدفعها صاحبها مضطرا ليحصل على حقه، ونخو ذلك وهو نوعان : النوع الأول: مـاكـان برضـا مالكهه عوضـا عـن عـين محرمـة: كثمن الكلب والمخدرات، أو عوضا عن عمل محرم: ككسب من الزنا، والرقص، والرشوة، وعمل الكهانة، ...أو كان عوضا في عقد منهي عنه لذاته: كعقود الغرر والمراهنات ، أو لوصفه: كعقد الربا ونهوه، كما يدخل في هذا النوع جحد الوديعة والعارية. النوع الثاني: ما كان بغير رضا مالكه سواء أكان بالقهر والمغالبة: كالغصب

وقطع الطريق، أم كان بالخفية: كالسرقة والتدليس والغش (r). ولماكان سبب التحريم-هنا- لم يتعلق بأصل المال، فبإن المال في ذاته ليس مذموما ، بل ينبغي أن يمدح ؛ لأنه سبب للتوصل إلى مصالح الدين والدنيا ، قال

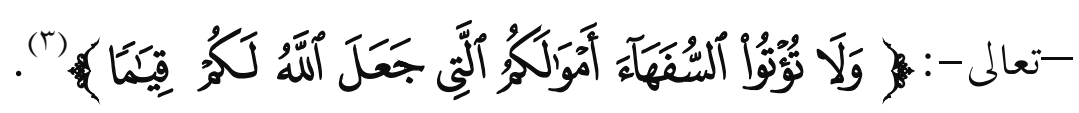

$$
\text { (1) الوجيز في أصول الفقه الإسلامي (1) / (1) (1). }
$$

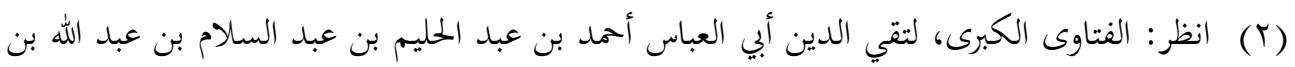

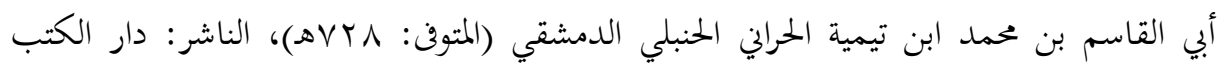

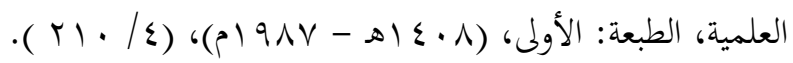

سورة النساء من الآية: (0). 
وهـذا مـا ذهب إليه الإمـام النووي فقـال:" قال أصححابنا: والعحرم نوعـان؛ ححرم لعينه: كالأواني والملاعق والجامر من ذهب أو فضـة، ومحرم بالقصد: بـأن يقصد الرجل بحلي النساء الذي يملكه: كالسوار والحلنحال أن يلبسه أو يلبسه غلمانه أو قصدات المرأة بحلي الرجال كالسيف والمنطقة أن تلبسه أو تلبسه

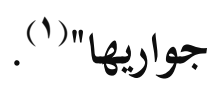

وبهذا يتبين الفرق بين المال الحرام لذاته الذي حرمه الله-تعالى -لأجل ما في أصله من صفة خبيثة لا يشك أحد في تحريمها، وبين المال المحرم لغيره الذي حرم لأجل مـا اقترن بـه مـن سبب خبيـث منهي عنه قطعا: كالغصـب، أو الربـا، أو نحوهما. المطلب الثاين

صور المال الحرام

إن للمـال الحـرام صورا لا تعـد ولا تحصى؛ للذا عندما نتحـدث عن صوره، ووسائل الحصول عليه، فنقول إغها لا تحصى كثرة، وتتعدد بتعدد الأماكن والأزمان، فهذه الصور منها القديم: كالغصب، ويكون بالاستياء على مال بغير حق على سبيل المحاهرة والمغالبة(r)، والاحتكار وهو : شراء السلع والبضائع وتخزينها ومنعها

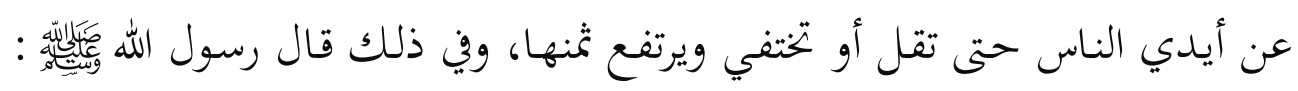
》الا يحتكر إلا خاطئي

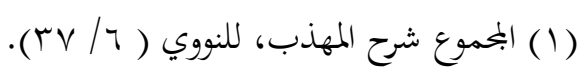

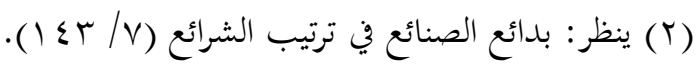

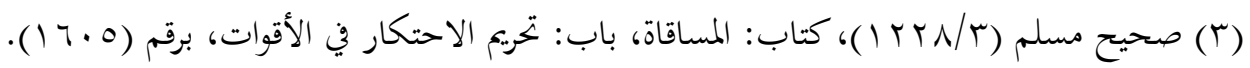
_q
} 
ومن الصور المستحدثة المرتبطة بالأظظمة المالية الجديدة: المال المكتسب

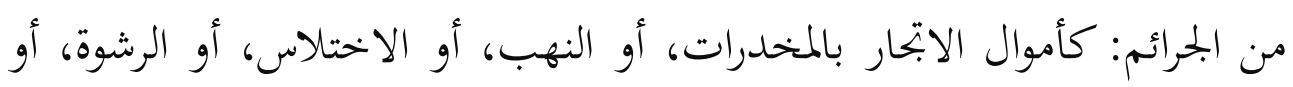

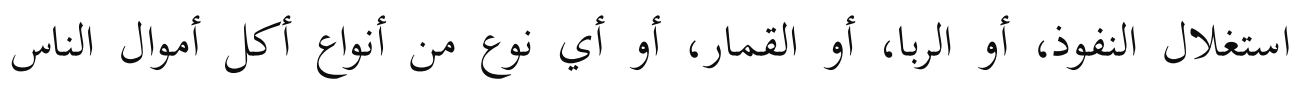

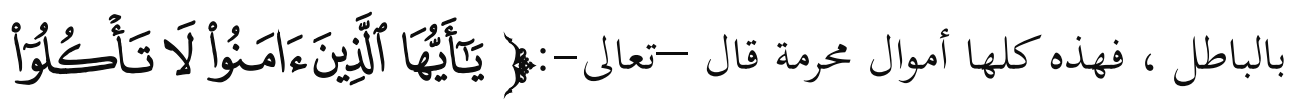

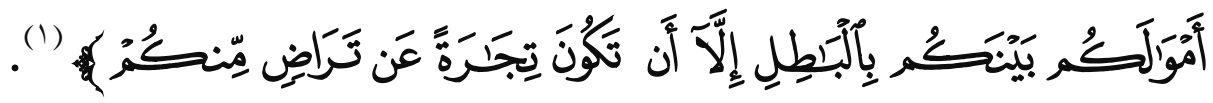

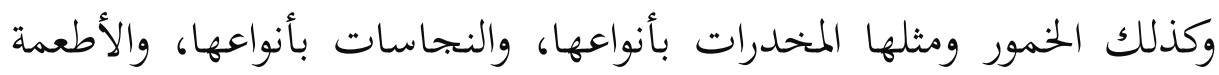

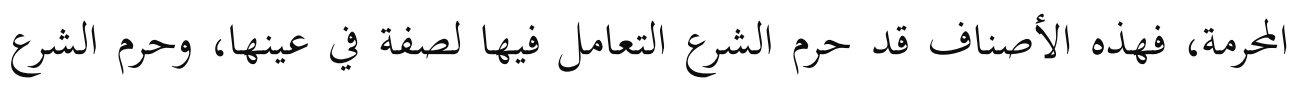
كافة ما يتعلق بها من أنشطة اقتصادية، كما حرم الشرع حيازة أو تملك أموال

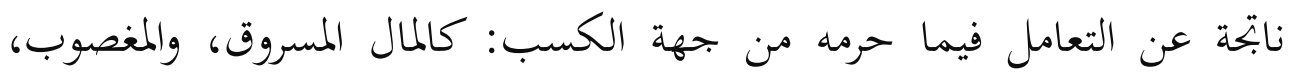

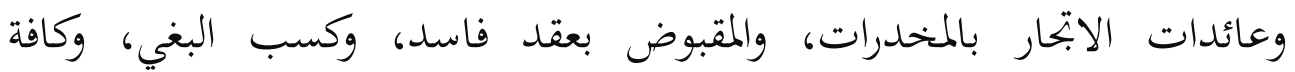

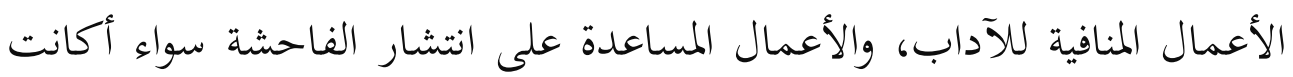

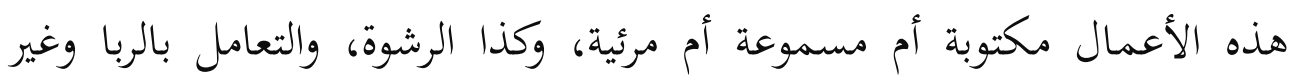
ذلك، ففضلا عن بحريم مصادر الكسب نفسها فإن الأموال الناشئة عنها تكون

$$
\text { أموالا محرمة، ولا يجوز الانتفاع بها (؟). }
$$

وقد تعددت صور المال الحرام في وقتنا الحاضر، وزادت مع استحداث أنظمة مالية جديدة، فمن هذه الصور ما يلي: أ- الكسـب الحـرام لأسباب غـير شـعية: كالرشـوة، والتـليس، والاختـلاس،

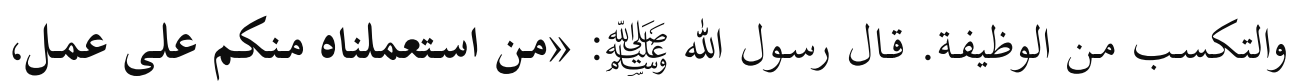

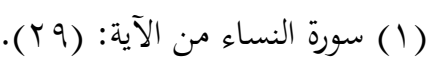
(r) ينظر : جريكة غسل الأموال في الفقه الإسلامي، د. عطية فياض، دار النشر للجامعات (صه广). 
فكتمنا مخيطا، فما فوقه كان غلولا يأتي به يوم القيامةها، قال: فقام إليه رجل أسود من الأنصار كأني أنظر إليه، فقال: يا رسول الله، اقبل عني عملك، قال:

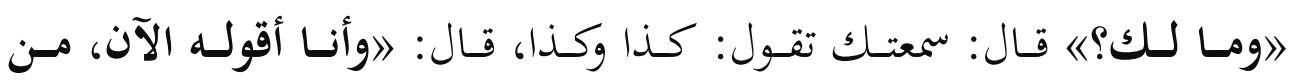
استعملناه منكم على عمل، فليجئ بقليله وكثيره، فما أوتي منه أخذ، وما في عنه انتهى" (1)، ونخو ذلك من الأموال الحرام. ب- المال الحرام الناتج من التجارة في أمور غير مشروعة تثار حولها الشبهات، أو أن المال أصبح حراما بسبب تعامل غير مشروع في بتحارة مباحة.

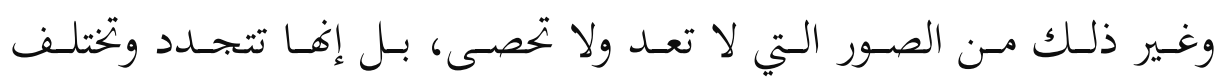

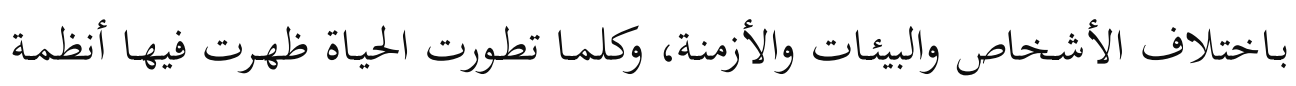

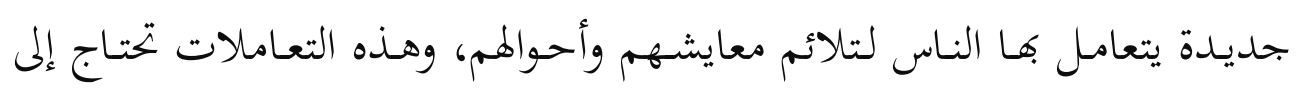

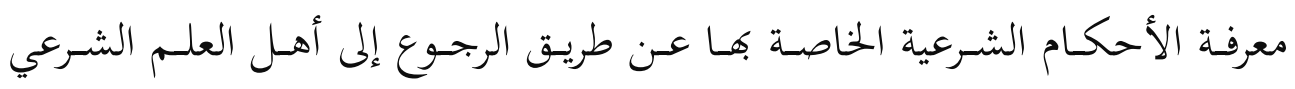

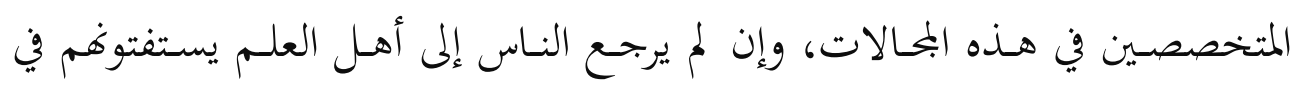

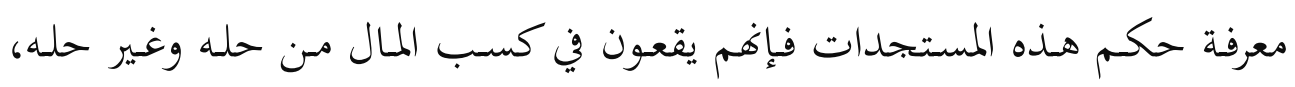
ومن ثم يظهر لدينا المال الحرام.

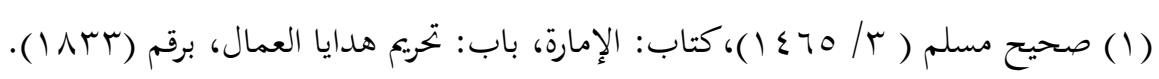




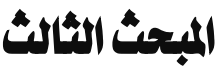 \\ التقأصيل الشرمي لقبول المال المغتسول

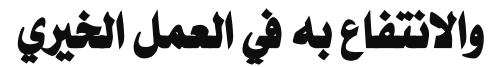

يمكن التأصيل لقبول المال المغسول وجواز الانتفاع به في العمل الخيري من

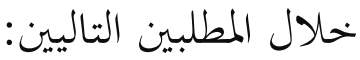

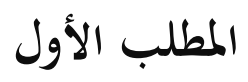

بيان أن الأصل في الشرع منع حيازة المال الحرام والانتفاع بله، وتجيم اكتسابه، ووجوب التخلص منه

إن الإسلام جاء لمصلحة العباد فأقر كل ما ينفعهم، وحظر كل ما يضرهم ويفسد عليهم معايشهم وأخلاقهم، ومن هنا جاء بتحيم الشرع الشريف لكل مال حرام لذاته أو حرام لغيره _ كما سبق بيان أقسامه وصوره _ـ؛ لأنه يضر بالأفراد

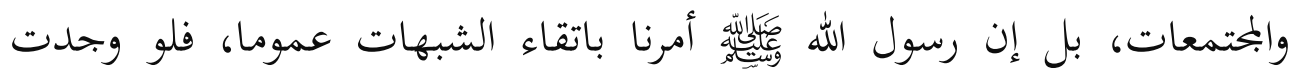
شبهة في مال وجب الابتعاد عنه.

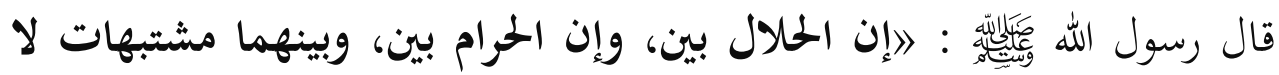
يعلمهن كثير من الناس، فمن اتقى الشبهات استبرأ لدينه، وعرضه، ومن وقع في الشبهات وقع في الحرام، كالراعي يرعى حول الحمى، يوشك أن يرتع فيه، ألا وإن لكل ملك حمى، ألا وإن حمى الله محارمه...ی" (1).

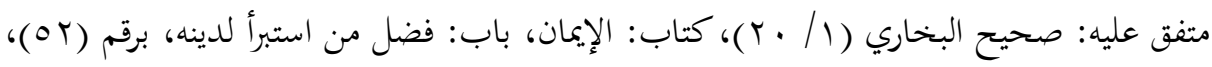

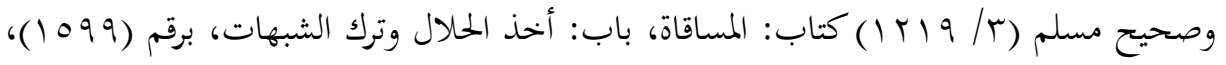
واللفظ لمسلم. 
وأوجب الله -تعالى -على كل مسلم الأكل من المال الطيب، فقال-تعالى-:

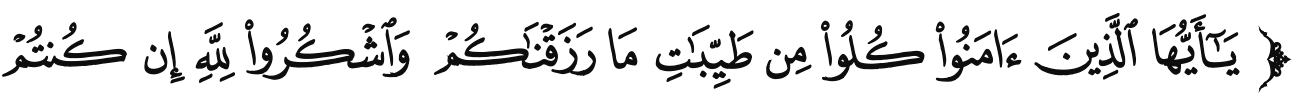

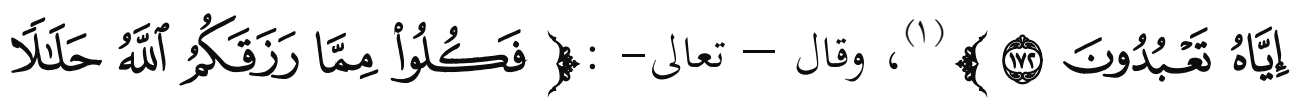

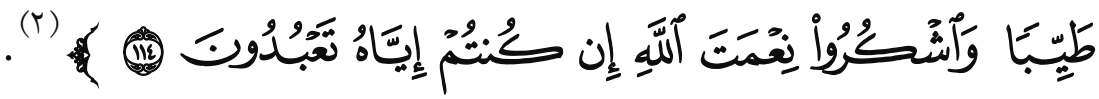
وحرم الله- تعالى - أكل مال الغير بالباطل، وهذا من أشد المال حرمة؛ لأنه

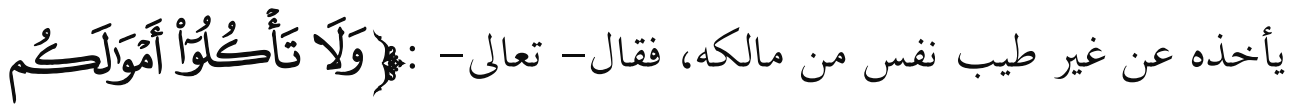

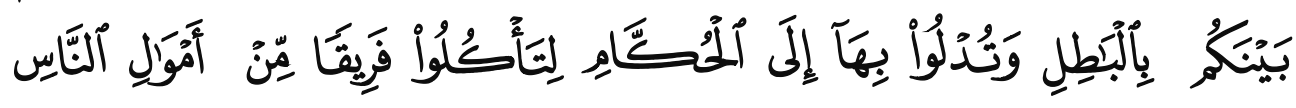

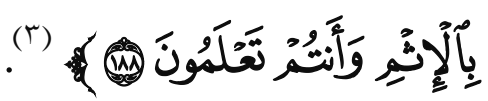
وأمر الله - تعالى - من ينفق ألا ينفق إلا من طيب ماله، وغهى عن إنفاق الخبيث منه تقربا إليه، وما ذلك إلا دلالة واضحة على تنفير الناس من المال الحرام

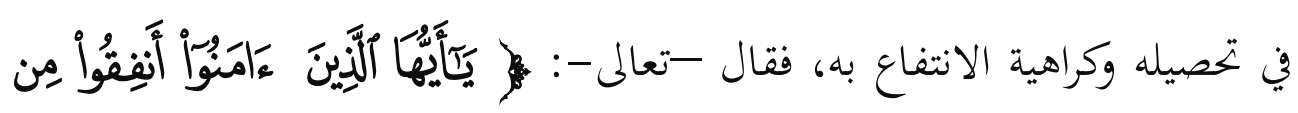

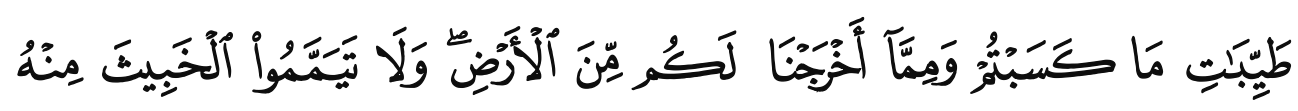

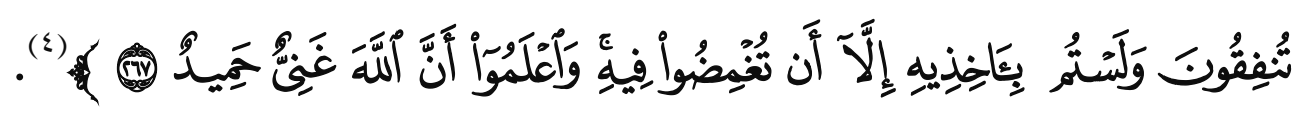

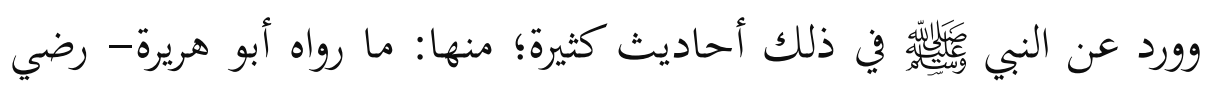

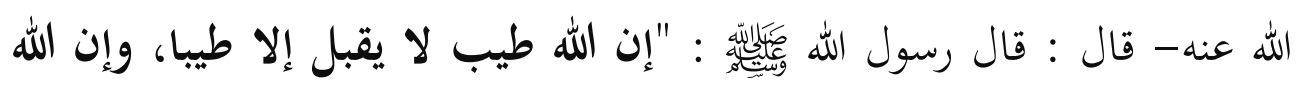




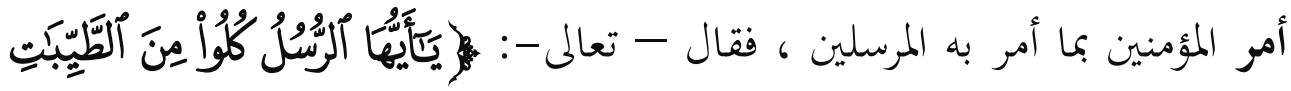

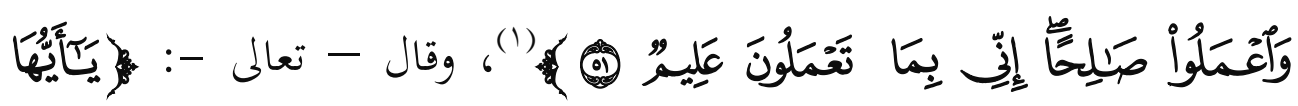

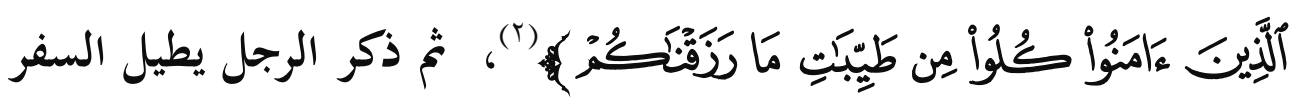

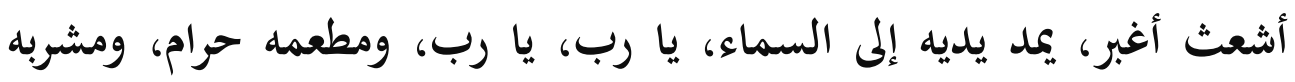

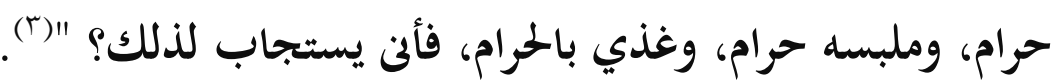
وهذه الأدلة وغيرها تدل دلالة صريحة على أن اكتساب الأموال المخرمة -

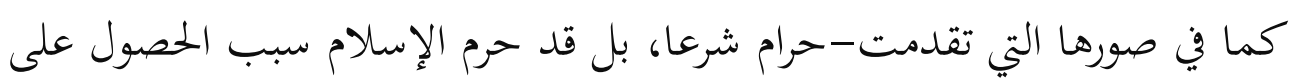

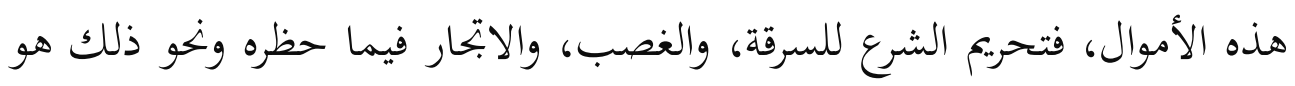

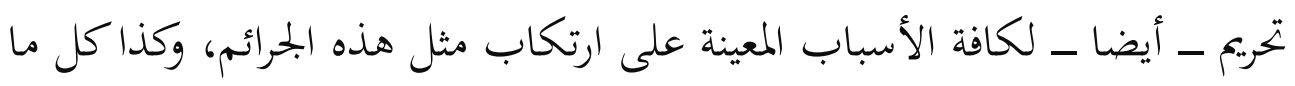
ينتج عنها من منافع. لكن قد يكون الحصول على هذا المال بطريق مباح شرعا وقد يكون بطريق

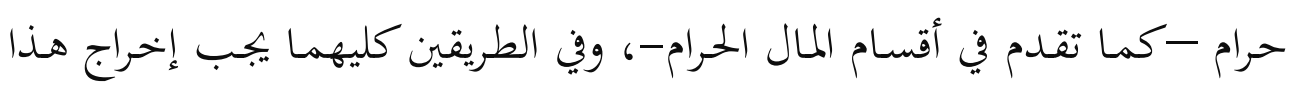

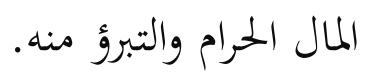

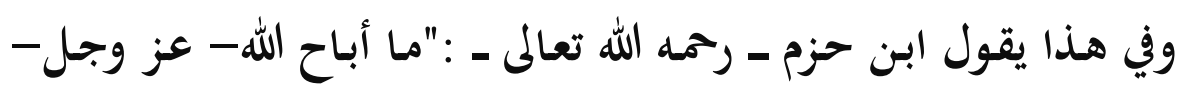

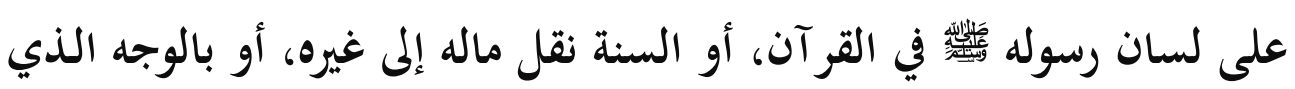

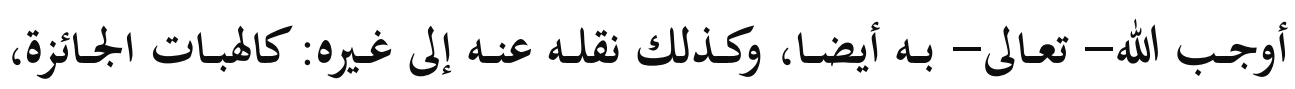

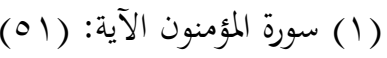

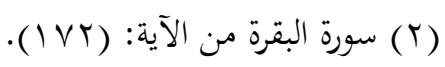

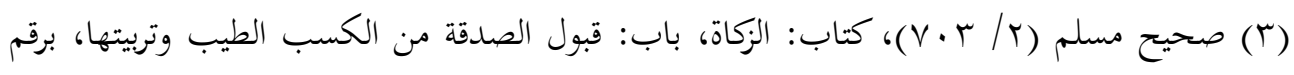
.$(1.10)$ 
والتجارة الجائزة، أو القضاء الواجب بالديات، والقصاص، وغير ذلك، مما هو منصوص.

فمن أخذ شيئا من مال غيره أو صار إليه بغير ما ذكرنا، فإن كان عامدا

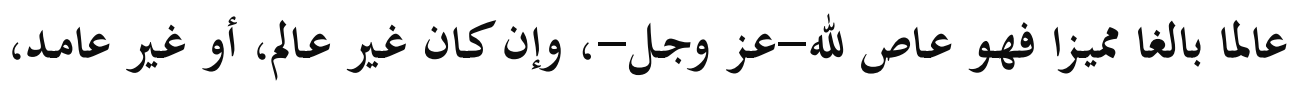

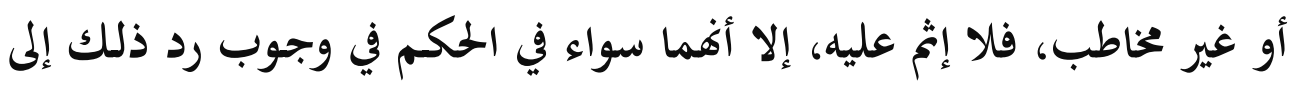
صاحبه، أو في وجوب ضمان مثله إن كان ما صار إليه من مال غيره قد تلفت عينه أو لم يقدر عليه" (1) ومن ثم نخلص إلى أن المال الحرام لا يدخل في ملك المسلم حقيقة؛ لأنه لم يدخل في حيازته بسبب شرعي صحيح، وقد حرم الشرع إبقاءه في يده هذا فضلا

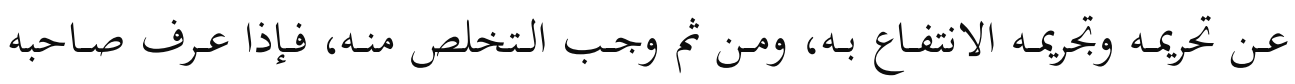

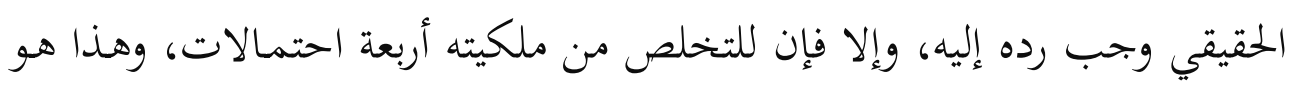
ما سوف نعرض له في الصفحات التالية. 


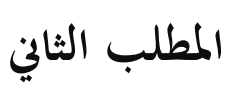

احتمالات التخلص من ملكية

المال المغسول والتصرف فيه

الـتخلص مـن المـال الحــرام وإخراجــه لا يعـدو أن يكـون لـه أحســ أربعـة

احتمالات (') (1)

الاحتمال الأول: أن يبقى المال الحرام في يد صاحبه المكتسب له من غير

الطـرق المشـروعة ، ولا يـتخلص منـه، ومسن ثم فهـو ينتفـع بـهـ كبـاقي أموالـه التي

$$
\text { اكتسبها من الحلال. }
$$

وهـذا الاحتمـال لا يصـح شـرعا؛ وذلك لأنه يؤدي إلى تملك هـذا المـال الحرام في أصله أو تملك المال الناتج عنه بسبب محرم، ومن تمح فلا يجوز أن يدخل هذا المال الحرام في ملك المسلم؛ لما سبق من أدلة القرآن والسنة التي تصرح بحرمة اكتساب هذا المال وتملكه، ووجوب التخلص منه.

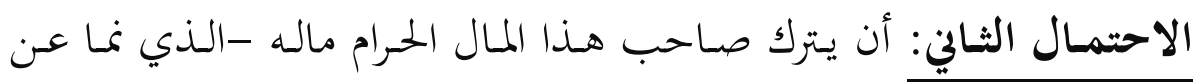
طريق حرم - لمن يتعامل معه؛ خوفا من الوقوع في تملك الحرام. وهـذا احتمـال مرفوض شـرعا؛ وذلك لأن ترك هـذا المـال الحرام - إلا أن يكون تركه استرجاعا لصاحبه الحقيقي -تترتب عليه أضرار كثيرة؛ منها: أن تركه فيه تشـجيع وإعانـة على الاسـتمرار ومواصـلة عمـل المحـرم، وهــا تعـاون على الإثم

(1) انظر: المصارف معاملاتما وودائعها للشيخ مصطفى الزرقا، منشورات المركز العالمي لأبحاث الاقتصاد

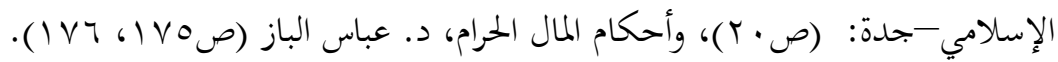




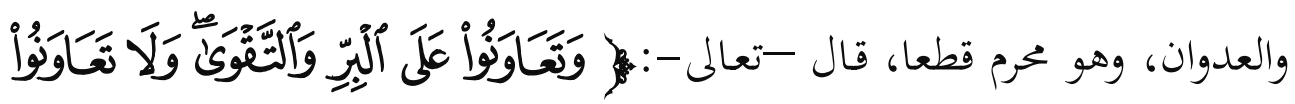

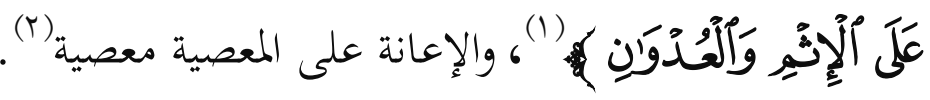

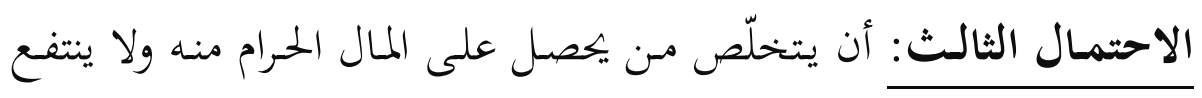

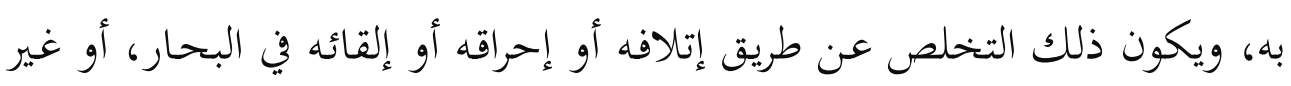
ذلك من وجوه الإتلاف.

وهـذا الاحتمــال غـير صـحيح شـرعا، ومخـالف لقواعـــ الشـريعة الغـراء ومقاصدها العظمى؛ وذلك لما يلي:

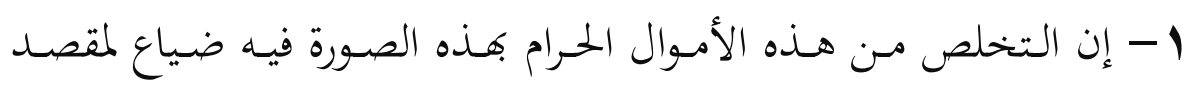

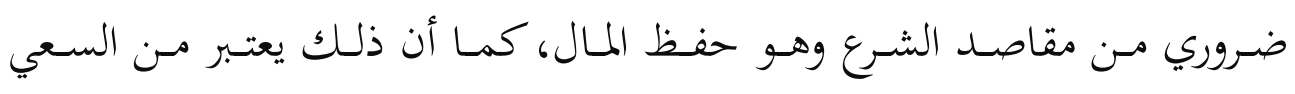

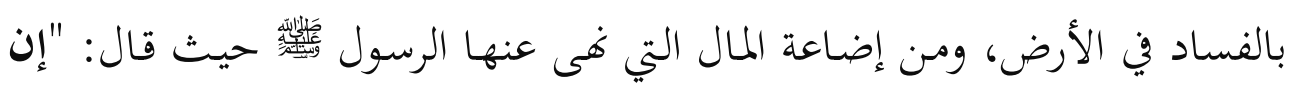

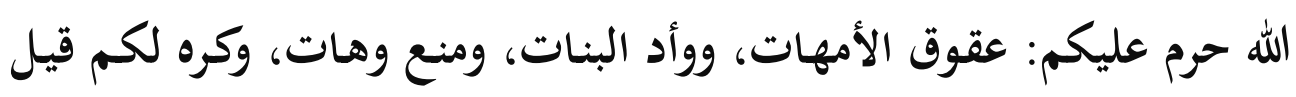

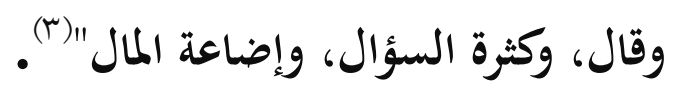

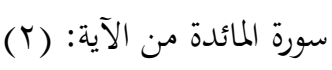

المصارف معاملاقما وودائعها للشيخ مصطفى أحمد الزرقا (صبr (Y) (Y).

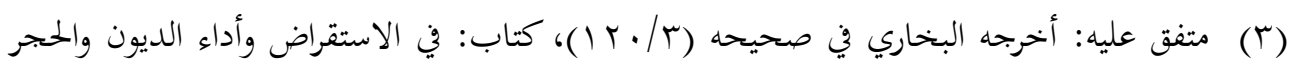

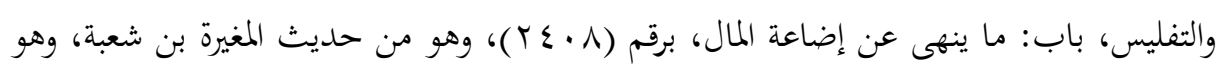

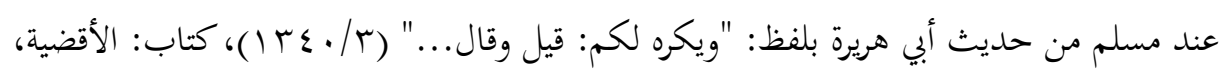

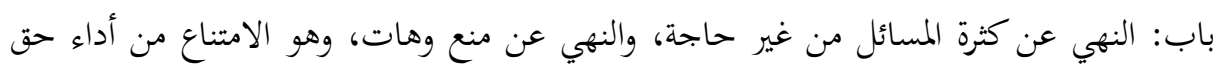

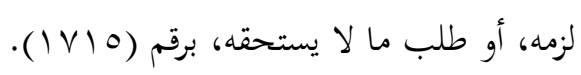


ومن ثم فلا يجوز إهلاك شيء من المال وإضاعته بلا انتفاعٍ أصلاً كقتل الدابة

بلا سبب موجب (1)

ץ- إن حيـازة المـال الحـرام مــا قـــ عمــت بـهـ البلـوى ووقوعـه في كـل زمـان

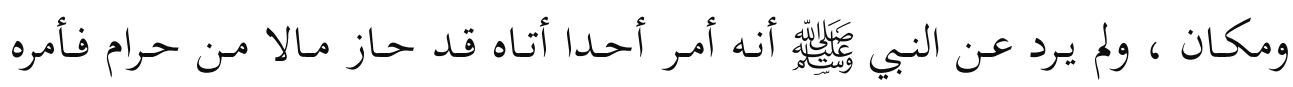
بإتلافه أو حرقه أو إلقائه في البحر.

ب-إن المال الحرام قد لا يكصى كثرة- أحيانا- خاصة في هذه الأزمان التي اشتبه فيها الحرام بالحلال، وكثرت موارد الحرام، وإذا قلنا بجواز إتلاف هذه الأموال فإننـا نكون بـذلك قـد فوتنـا على أمتنـا هـذه الأموال وأهـدرنا منفعتهـا، وهـذا مـن الضرر المحرم، والشريعة لم تأت بالضرر، بل جاءت بالمنع منه وقطعه؛ فـ "لا ضرر

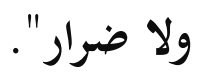

وقد احترز الفقـه الإسلامي على اختلاف مذاهبه مـن إتلاف الأموال المحرمة على ما فيها من الضرر (r). فبإتلاف آلات اللهو والفسـاد: كالبربط، والطبـل، والعود ونحو ذلك، ينبغي أن

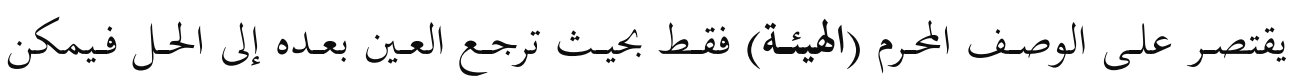
الانتفاع بها، فإن بحاوز الإتلاف الوصف المحرم إلى العين؛ فإنه يجب ضمان العين ناقصة

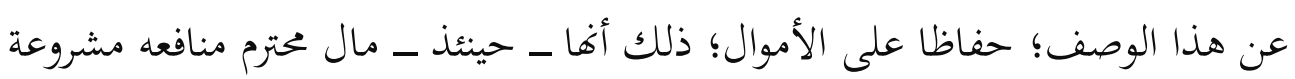
ومأذون فيها؛ فيعد إتلافه ضررا معتبرا فيحرم، ويمنع منه ويعاقب عليه.

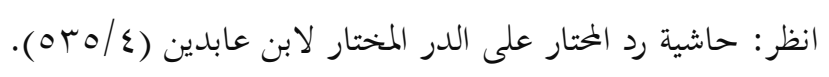

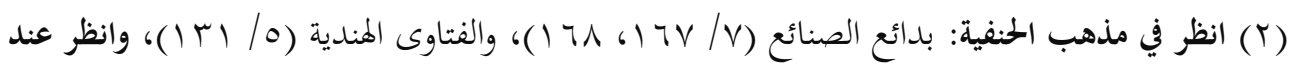

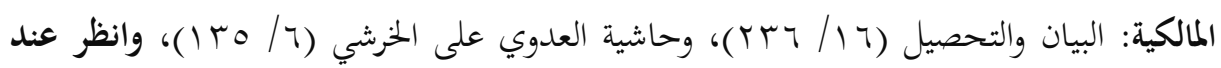

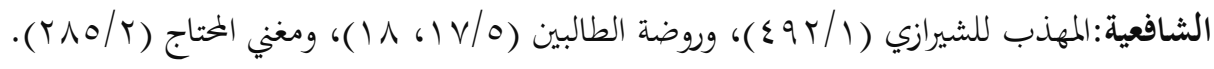


فمثلا آلات الملاهي تكون مركبة من عين هي " الحشبب " وهو حالال، ومن وصـف هـو " الصـنعة " التي الخـذت مـن الخشـب هيئة الـبربط ...، فبإذا بتـاوز الإتلاف الهيئة إلى الخشب الذي هو العين؛ فإنه يكون إتلافا محرما يوجب الضمان على المتلف؛ لأن عين الخشب حلال يمكن الانتفاع به. ومثـل هـذا إتـلاوف النـرد ؛ " لأنسه يمكـن أن يجعـل هـذه الأشـياء سـنجات

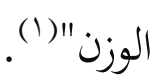

ومنطلق الفقه في ذلك: مراعاة الحفاظ على الأموال بقدر الإمكان، وتضييق السبل التي تئدي إلى إتلافها والنيـل منهـا، وإبقائها عاملـة في تحصيل مـا أباحسه الشرع من المنافع؛ لتيسير معايش الناس ورفع الحرج عنهم والوفاء بحاجاهم والقيام بمصالحهم.

وهــا معـنى عبقــي لإِتهالاف المشـروع يقـره الفقـه الإسـلامي ويتميز بـه: النقض والتغيير (تغيير الصورة) بكيث تفوت الهيئة الحُمة، وتبقى العين - التي هي مـادة الصـنع - صـالحة للانتفـاع بها لا أن تفوت العين بالكليـة؛ ولهذا فإن الشافعية يعبرون عنه بـ " الفصل " لا الكسر والإتلاف (r). الاحتمال الرابـع: أن يبحـث صاحب هذا المال الحرام عن مصرف أو عمل شرعي خيري ينفق فيه هذا المال، وهذا الاحتمال هو أقرب الاحتمالات للصواب

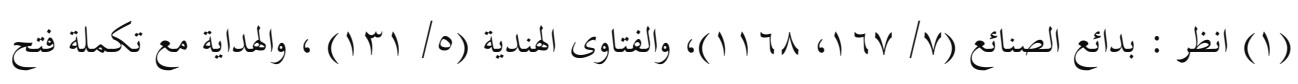

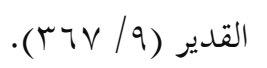

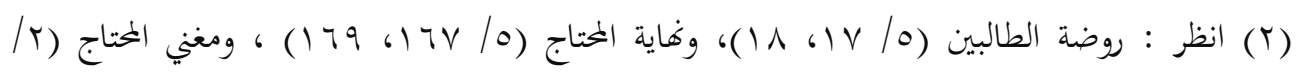

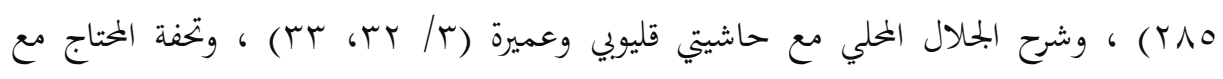

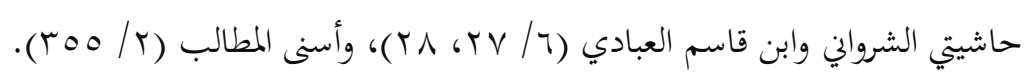
$-\varepsilon q_{-}$ 
وأوفقها لمقاصد الشريعة الغراء؛ وذلك لأن فيه ارتكاب أخف الأضرار النابتحة

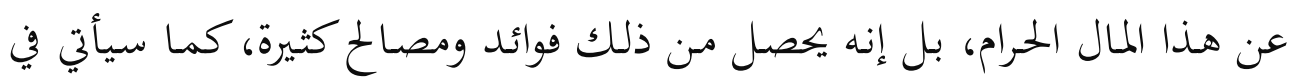
بيان الأبواب التي يجوز إنفاق فيها هذه الأموال .

ش*رأي شيخ الإسلام ابن تيمية في كيفية إنفاق هذا المال

اختار شيخ الإسلام ابن تيمية -رحمه الله تعالى - جواز أن يصرف في المصالح

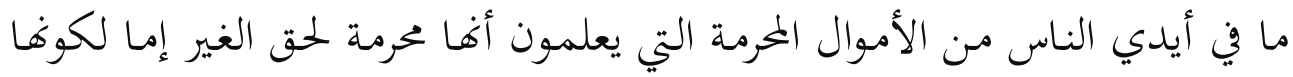

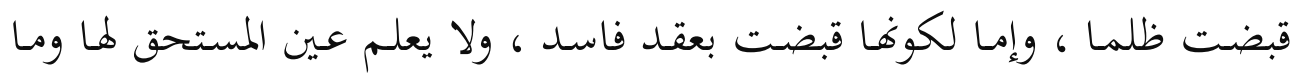

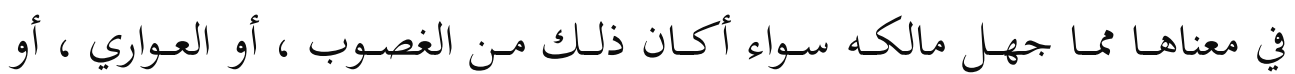
الودائع، وجعل ذلك مبدأ شرعيا وقاعدة مستقرة .

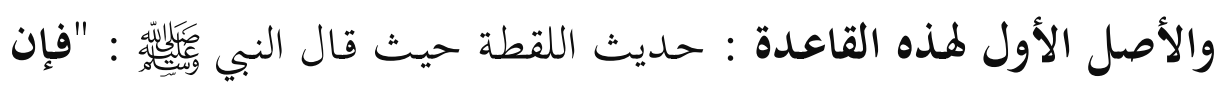
وجدتَّ صاحبها فارددها إليه ، وإلا فهي مال الله يؤتيه من يشاء"((1) ، وينبني عليه : أنه إذا عدم المالك انتقل الملك عنه بالاتفاق.

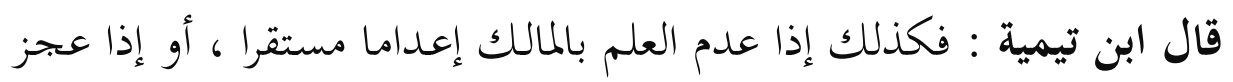

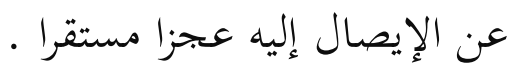

(1) أخرجه الدارمي من حديث الجارود ، قال: "نقال رجل يا رسول الله اللقطة بخدها ؟ قال : انشدها

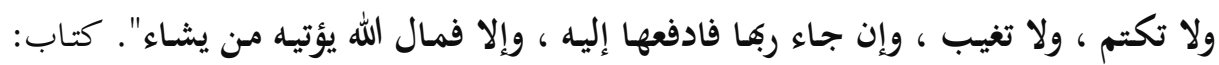

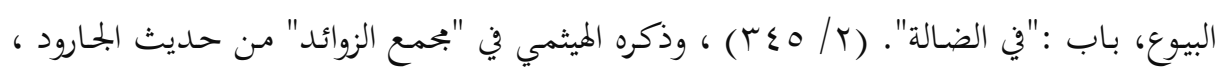

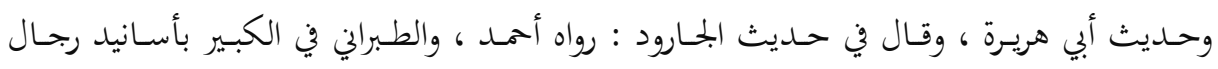

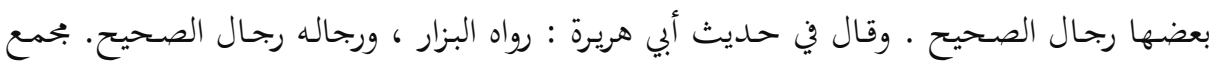
الزوائد (ع/ (1 ) ). 
ويتأكد هـا الأصل بمـا اتفق المسلمون عليه : مـن أنه إذا مـات الرجل ، ولا وارث لـه معلوم فمالـه يصـرف في مصـالح المسـلمين ، مـع أنه لا بـد - في غالـب الخلق - أن يكون له عصبة بعيدة ، لكن جهلت عينه ، ولم ترج معرفته ، فجعل

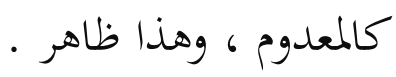
وعلى هـذا فمـا لا يعلـم بجال ، أو لا يقـدر عليه بحـال ، هـو في حقنـا بمنزلة المعدوم ، فلا نكلف إلا بما نعلمه ، ونقدر عليه . وكما أنه لا فرق في حقنا بين فعل لم نؤمر به ، وبين فعل أمرنا به جملة عند فوات العلم أو القـدرة - كمـا في حق الجحنون والعاجز - كذلك لا فرق في حقنـا بين مال لا مالك له أمرنا بإيصاله إليه ، وبين ما أمرنا بإيصاله إلى مالكه جملة إذا فات العلم به أو القدرة عليه ؛إذ الأموال كالأعمال سواء.

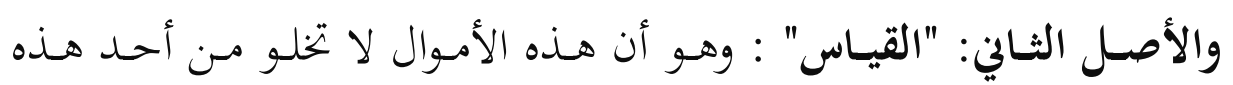
الثلاثة : إما أن تتلف ، وإما أن تحبس ، وإما أن تنفق .

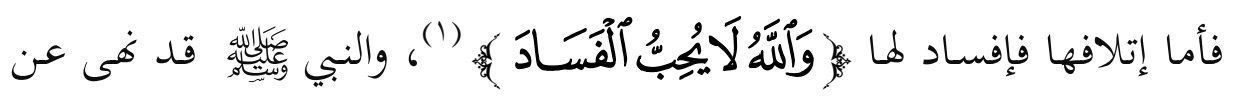
إضاعة المال ، وإتلاف المال إنما يباح قصاصا ، أو لإفساد مالكه . قال ابن تيمية : ولفذا لم أعلم أحدا من الناس قال إن الأموال المحترمة المجهولة المالك تتلف ، وإنما يهكى ذلك عن بعض الغالطين من المتورعة : أنه ألقى شيئا من ماله في البحر ، أو أنه تركه في البر ، ونحو ذلك ، فهؤلاء بتحد مـنهم حسن القصد ، وصدق الورع ، لا صواب العمل .

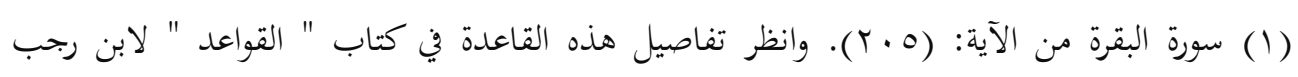

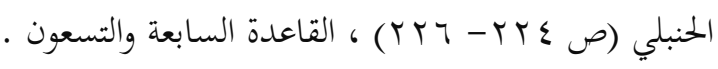


وأما حبسها دائما أبدا إلى غير غاية منتظرة ، بل مع العلم أنه لا يرجى معرفة

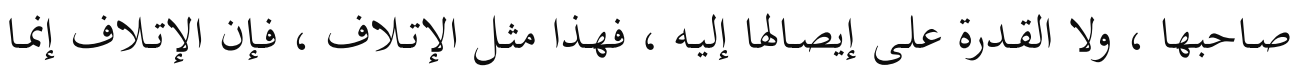

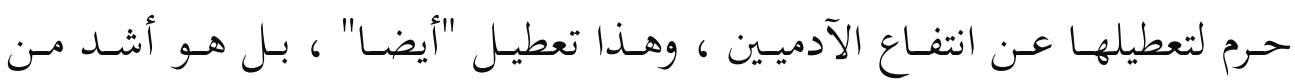
وجهين:

أحدهما : أنه تعذيب للنفوس بإبقاء ما يحتاجون إليه من غير انتفاع .

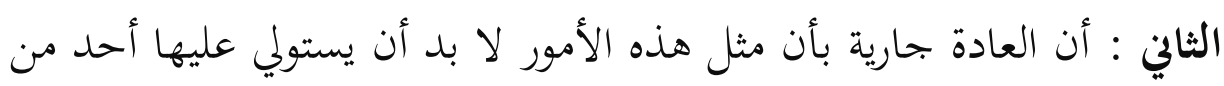

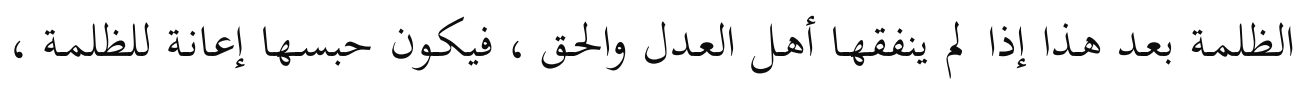

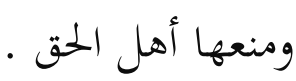

فإذا علم هذا لم يبق إلا أها تنفق في مصالح الخلق ، وتصرف في جميع جهات

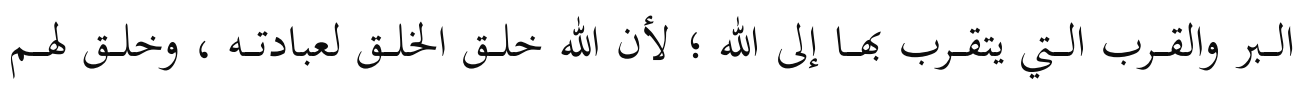

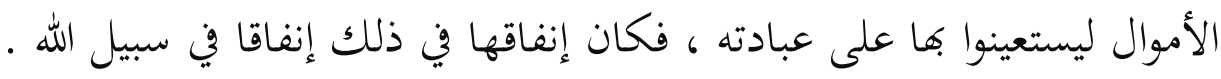

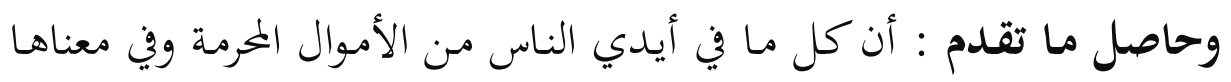

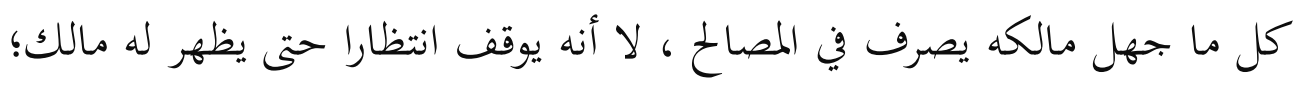

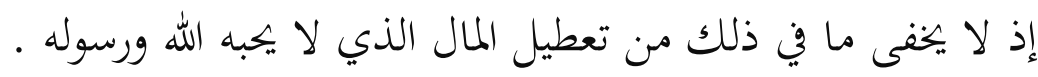

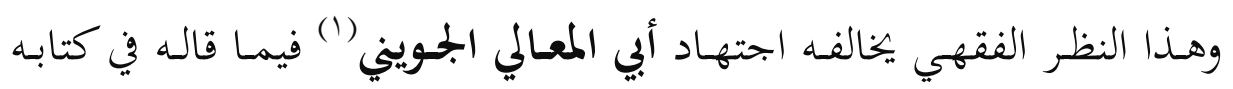

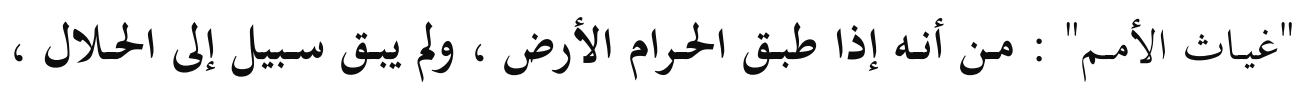

(1) هو: عبد الملك ابن الإمام أبي محمد عبد الله بن يوسف، أبو المعالي، ولد سنة (9 اعهـ). من

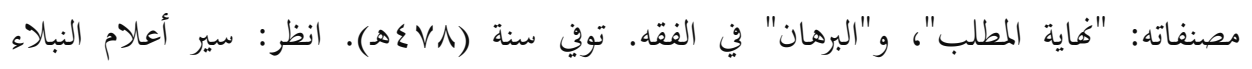

$$
\text { ) }
$$


فإنه لا يباح للناس إلا قدر الحاجة من المطاعم ، والملابس ، والمساكن ، كما

لو استولت الملوك الظلمة على الأموال بغير حق ، وبثنها في الناس (1).

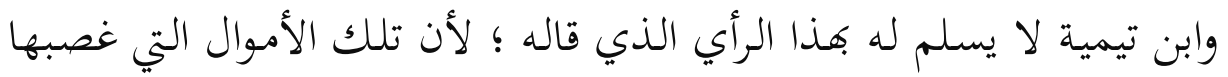

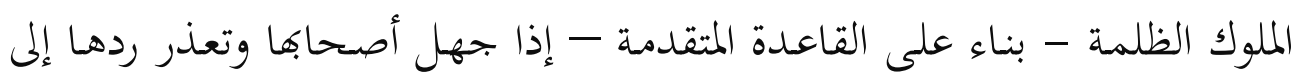

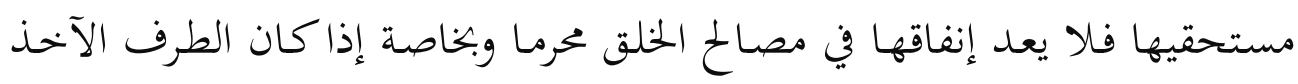

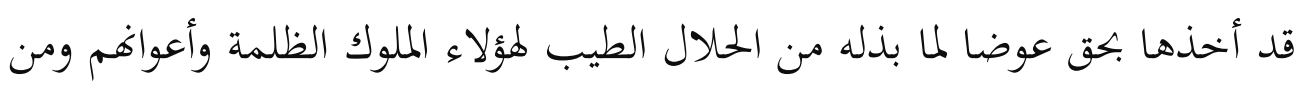

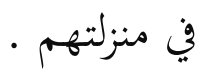

والـذي كـــف إليسه - مـن وراء هـــا - : التوسـعة على النـاس في أمسور

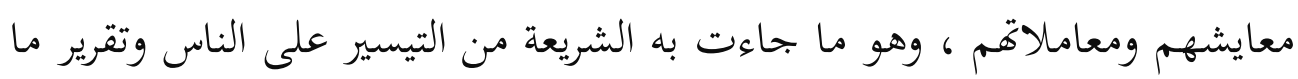
فيه مصلحتهم وعدم التضييق عليهم .

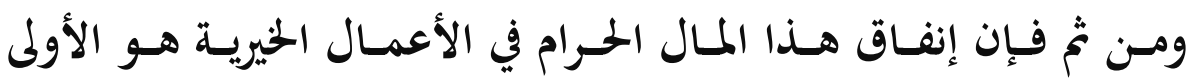

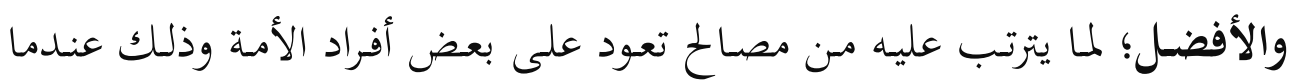

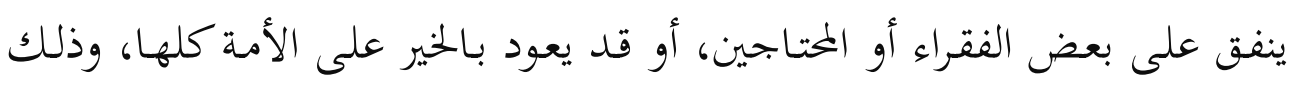

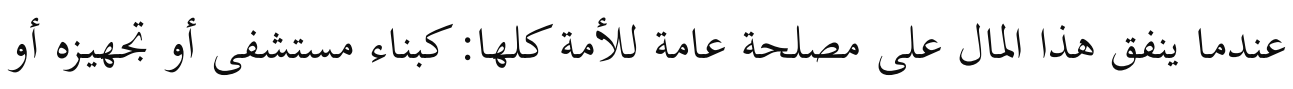

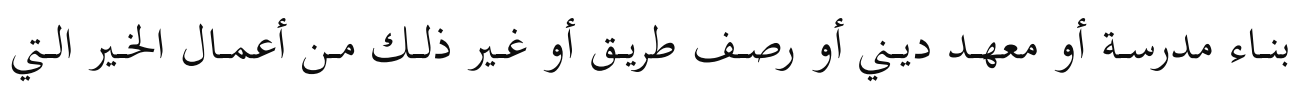
تتجدد باختلاف الأزمنة والأمكنة.

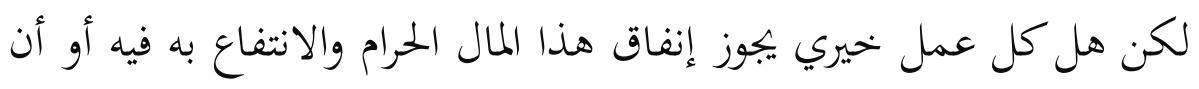

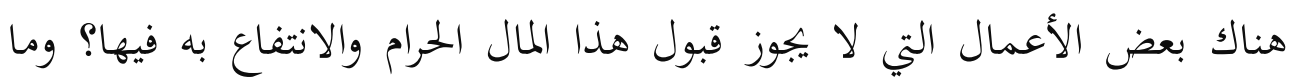

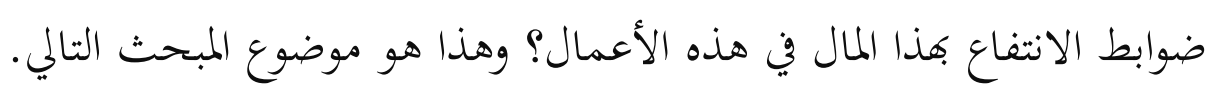

(1) انظر: غياث الأمم في التياث الظلم ، تحقيق : الدكتور عبدالعظيم الديب (ص V ؛ وما بعدها). -Or. 


\section{المبحث الرابح

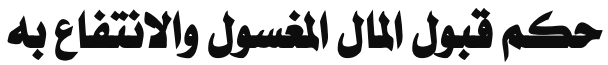 \\ في العمل الخيري، وضوليط ذلكلك}

إذا كان المال المغسول بحوزة شخص وأراد التخلص منه أو أعطاه لغيره وأمره

أن يتخلص منه، فما المجالات التي يصح أن يصرف فيها هذا المال؟ وما المجالات التي لا يصح صرفه فيها؟ وكذا إذا ورد هذا المال إلى جهة من جهات العمل الخيري فما الوجوه التي يصح أن تنفق فيها هذه الجههة المال المغسول؟ وكيف تتعامل مع هذا المال؟ وما ضوابط ذلك شرعا؟ يمكننا معالجة هذه الأسئلة من خلال المطلبين التاليين: المطلب الأول

حكم قبول المال المفسول والانتفاع به في العمل الحيري لا خلاف بين الفقهاء قديما وحديثا على وجوب التحلل من المال الحرام، لكنهم اختلفوا في حكم قبول هذا المال والانتفاع به في العمل الخيري؟ قال النووي -رحمه الله-: "قال الغزالي: إذا كان معه مال حرام وأراد التوبة والبراءة منه - فإن كان له مالك معين - وجب صرفه إليه أو إلى وكيله، فإن كان ميتا وجب دفعه إلى وارثه، وإن كان لمالك لا يعرفه ويئس من معرفته فينبغي أن يصرفه في مصالح المسلمين العامة: كالقناطر، والربط، والمساجد، ونحو ذلك مما يشترك المسلمون فيه، وإلا فيتصدق به على فقير أو فقراء"(() وهذا ما ذهب إليه كثيرون من الفقهاء(r)

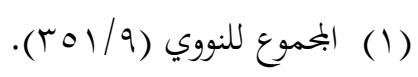

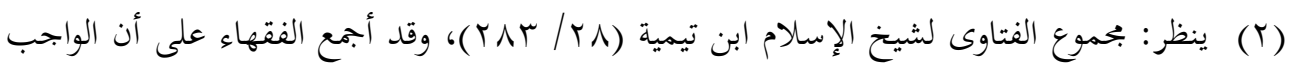

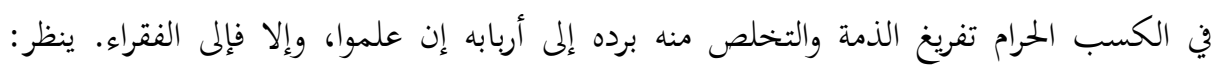


لكن هناك بعض المحالات التي اختلف الفقهاء في جواز قبول المال الحرام فيها، ومنها:

أولا: استخدام المال الحرام في بناء المساجد أو شراء المصاحف أو نهو ذلك

$$
\text { من أمور العبادات. }
$$

ثانيا: استخدام المال الحرام في النفقة على الفقراء والمساكين، والمصالح العامة

للمسلمين.

ونتناول -هنا- حكم استخدام المال الحرام في هذه المحالات، ثم نخلص

بعد ذلك لبعض الضوابط الشرعية التي تبينت لنا لقبول المال المغسول وإنفاقه في هذه البحالات في العمل الخيري.

أولا: حكم غسل المال الحرام في بناء وتعمير المساجد أو شراء

المصاحف ، وما في معنى ذلك من العبادات الحالصة لله -عز وجل -.

اختلف الفقهاء - رحمهم الله - في غسل المال الحرام والانتفاع به في

$$
\text { العبادات على قولين: - (1) }
$$

القول الأول: عدم جواز غسل المال الحرام والانتفاع به في العبادات: من بناء المساجد، وتعمير دور العبادة وغير ذلك؛ لأنه مال حرام وخبيث فلا يجيوز أن يدخل في بناء المساجد؛ وهذا هو مذهب الحنفية(')، وقول عند المالكية(؟) .

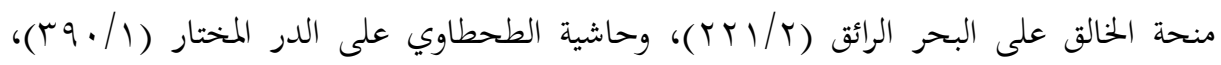

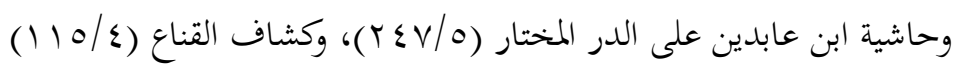

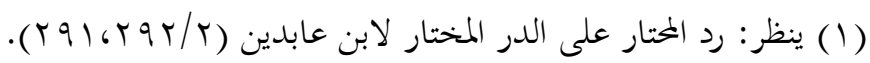

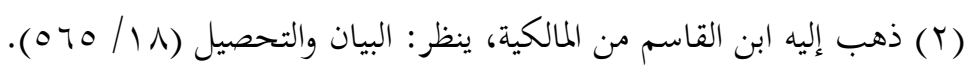

$$
\begin{aligned}
& \text { - } 00 \text {. }
\end{aligned}
$$




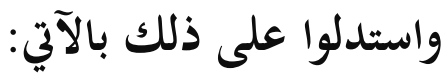

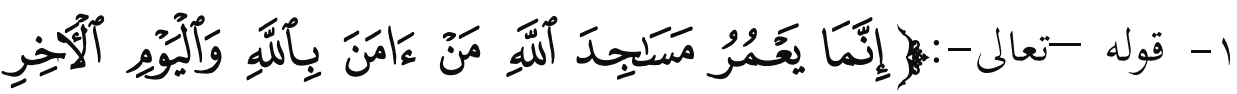

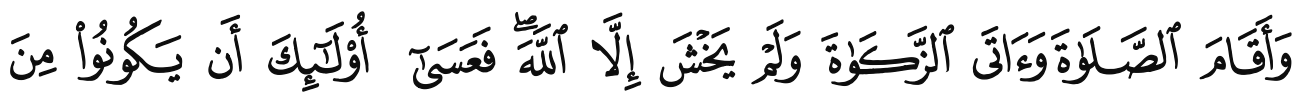

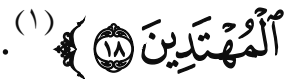

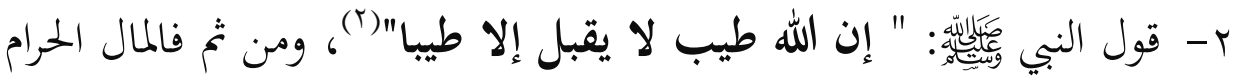
لا يصلح أن يدخل في بناء بيت من بيوت الله - عز وجل--، بل تصان المساجد

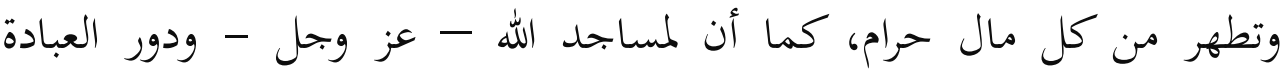
خصوصية فلا يصح أن تقام أو تُبنى بهذا المال ("). r- إن جعل المال الحرام في بناء المساجد، وغيرها من العبادات من باب الإكرام والإحسان لهذه الأموال الحرام، والحرام لا يكون سببا للإكرام والإحسان.

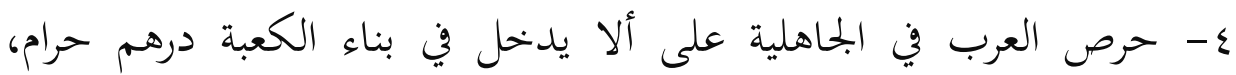

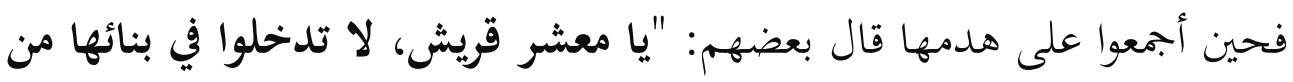
كسبكم إلا طيبا، لا يدخل فيها مهر بغي، ولا بيع ربا، ولا مظلمة أحد من

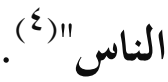
القول الثاني: جواز غسل المال الحرام والانتفاع به في العبادات من بناء

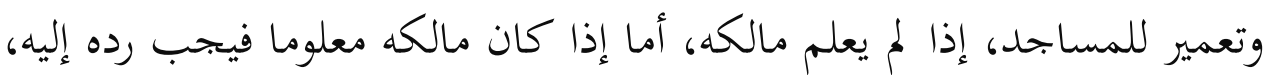

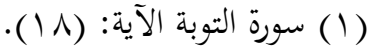

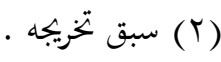

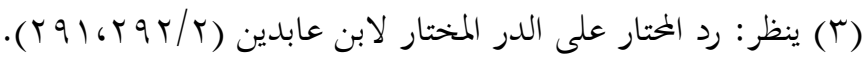

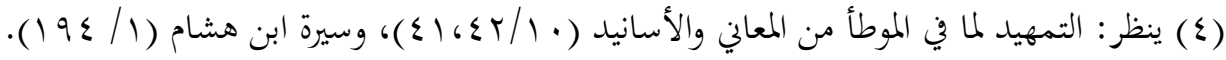
-07 . 
وهو قول عند الحنفية(')، ومذهب الشافعية(؟) وبعض المالكية(؟)، والحنابلة(؟). واستدلوا على ذلك بالآتي:

1- إن المال الحرام الذي يُدفع إلى الفقير لا يكون في حقه حراما، بل هو له حلال طيب يتصرّف فيه كما لو كان من حرّ ماله، فإذا دُفِع المال الحرام لبناء مسجدٍٍ كان حلالا طيبا، ولم يكن حراما" (0). r- إن صفة الحرمة في المال لا تمنع من تشييد وبناء المساجد؛ لأن مصير المال الحرام هو المصالح العامة، كما أن الحرمة لا تثبت في المال، بل تثبت في ذمة من كان سببا في وجود المال الحرام(1). القول الراجح: هو القول الأول القائل بعدم جواز بناء المساجد وتعميرها ونو ذلك من العبادات، من هذه الأموال؛ للآتي: 1- إن المساجد بيوت الله، أضافها الله - عز وجل - إلى نفسه إضافة تشريفٍ، فإذا كان الأمر كذلك فلا يصح أن يكون غير الطيب في بيتٍ من

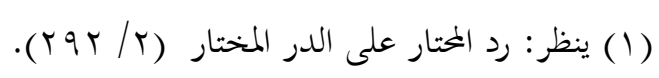

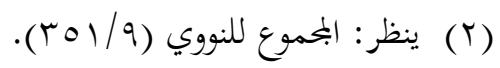

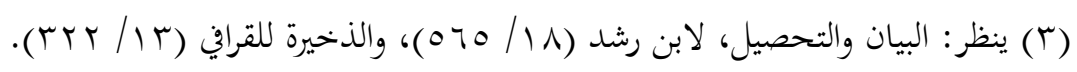

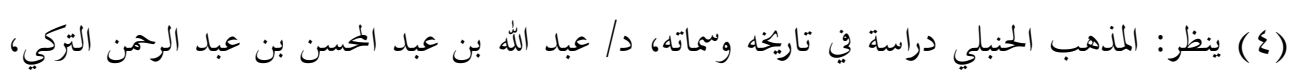

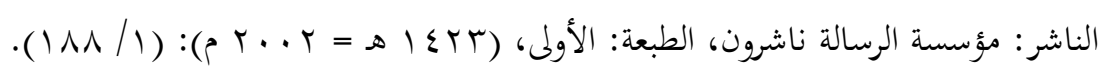

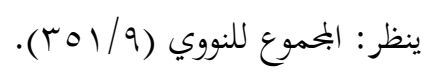

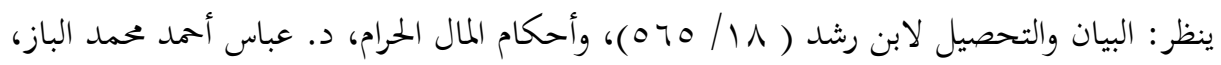

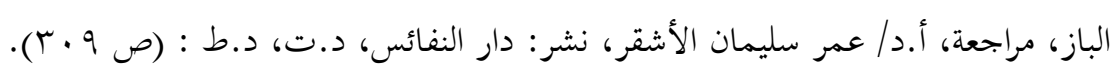


بيوت الله(1) كما أن الفقهاء وضعوا شروطا وضوابط لبناء المساجد، وتعميرها، والمحافظة عليها، فالأولى المحافظة عليها من المال الحرام(r). r - إن ما ذهب إليه ابن رشد من أن الحرام يثبت في الذمة لا في العين لا يعتد

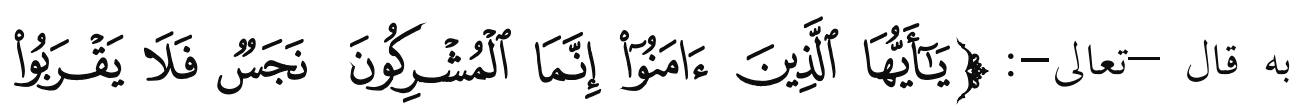

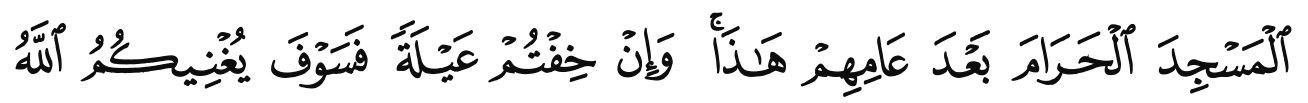

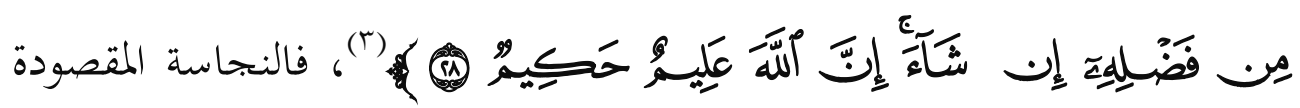
في الآية هي النجاسة الحكمية، وليست الحقيقية في البدن أو الثياب، فجمهور المفسرين على أنه ليس بنجس البدن والذات؛ لأن الله- تعالى - أحل طعام أهل

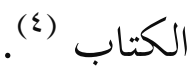
r- ليس كل ما جاز صرفه للفقراء والمساكين جاز صرفه للمساجد؛ وذلك أن الشارع أذن للفقير أن يأخذ هذا المال المحرم وينتفع به، ويصير في حقه حلالاً؛ كي لا يبقى المال بغير مالك، ولا تستمر معه صفة الحرمة، بخلاف بيوت الله فهي في غنى عن هذا المال الحرام، ويدخل في ذلك عدم إقامة دورٍ للقرآن، أو طباعة المصاحف من هذه الأموال.

(1) ينظر: التبصرة للخمي (1/ 1 • ع، 9 • ع)، وأسهل المدارك اشرح إرشاد السالك في مذهب إمام

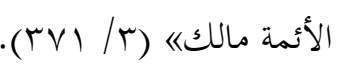

$$
\begin{aligned}
& \text { ينظر : كشاف القناع عن متن الإقناع (Y/ \& ع (Y)، وما بعدها. } \\
& \text { (T) التوبة الآية:( ( ) }
\end{aligned}
$$

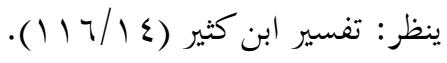


ثانيا: حكم غسل المال الحرام في النفقة على الفقراء والمساكين، والمصالح العامة للمسلمين.

اختلف الفقهاء في غسل المال الحرام وقبوله في النفقة على الفقراء والمساكين فهل يجوز ذلكبأو أنه يُصرف في المصالح العامة للمسلمين من رصف طرق، وغير ذلك؟ فمن قال إنه يجوز انتفاع الفقراء والمساكين بالمال الحرام، قال بعدم توجيهه إلى المصالح العامة للمسلمين كرصف وتعبيد الطرق، والاقتصار في إنفاقه على الفقراء والمساكين.

ومن قال إنه يجوز الانتفاع بالمال الحرام في المصالح العامة للمسلمين وفق ما يراه أهل الحل والعقد قال -أيضا- بجواز الانتفاع للفقراء والمساكين، وقد اختلف الفقهاء في ذلك على ثلاثة أقوال :

القول الأول: اختصاص الفقراء والمساكين فقط بالانتفاع بالمال الحرام، ولا ينفق في شيء من مصالح المسلمين العامة، وهو قول الحنفية(')، والمالكية(T)، والحنابلة) (r)

ووجهتهم في ذلك: أن الفقراء مستحقون لهذه الأموال؛ لأهم المالكون لها، ولا تتحقّق هذه الملكية إلا بالقبض، فإذا صُرفت في المصالح العامة لم يتحقّق القبض، والأدلة الشرعية تؤيّد ملكية الفقراء لهذا المال، وليس ملكية المسلمين له،

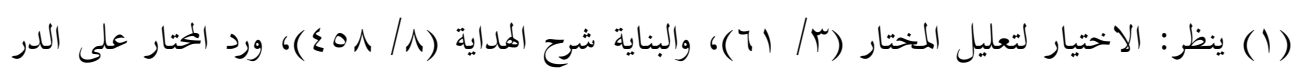

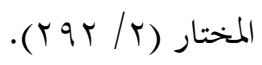

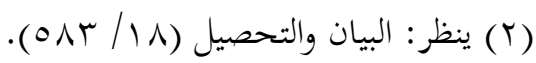

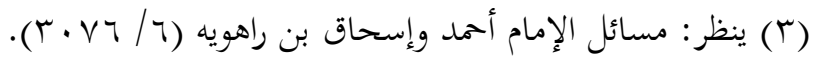

$$
\begin{aligned}
& \text {-09 _ }
\end{aligned}
$$


كما أنه إذا قيل بإنفاقها في مصالح المسلمين العامة ربما تؤخذ وتُوضع في غير موضعها فتضيع على مستحقيّها (1). القول الثاني: توجيه المال الحرام للمصالح العامة للمسلمين: كبناء القناطر وسد الثغور ، ولا ينتفع به الفقراء والمساكين، وهو قول متأخري المالكية(؟)، والشافعية) (َ)

ووجهتهم في ذلك: أن من تاب من المال الحرام وأراد التخلص منه، فالأصل خروجه عنه لبيت مال المسلمين، أو لمن يعمل ما يعمله أمير المسلمين من صرفه في مصالحهم الأهم فالأهم (\&). القول الثالث: جواز الانتفاع بالمال الحرام في النفقة على الفقراء والمساكين، والمصالح العامة للمسلمين دون تفريق بينهما، فإن أراد مالك المال الحرام التخلص منه بإعطائه للفقراء والمساكين جاز له ذلك دون حصوله على أجر من الله- عز وجل-، وإن أراد استخدامه في بناء سدود، أو قناطر أو غير ذلك مما فيه مصالح

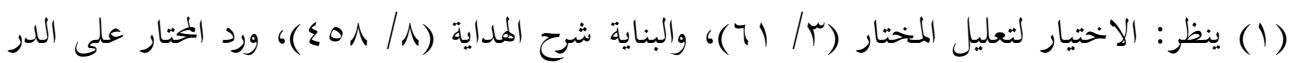

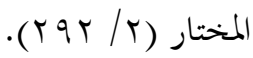

(r) ينظر: المعيار المعرب والجامع المغرب عن فتاوى أهل إفريقية والأندلس والمغرب، لأبي العباس أحمد بن

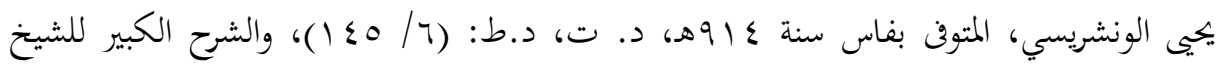
الدردير وحاشية الدسوقي (rVV/r)

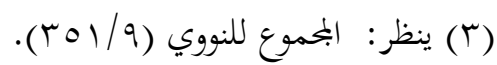

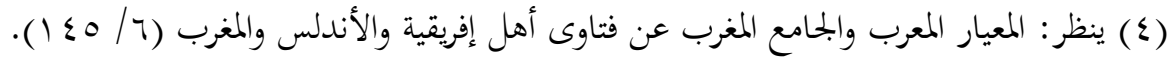


عامة المسلمين فله ذلك، وهو قول بعض المالكية(')، وقول عند الحنابلة نسب

$$
\text { لشيخ الإسالام ابن تيمية(r). }
$$

قال شيخ الإسالام ابن تيمية: " فهذه الأموال التي تعذّر ردها إلى أهلها لعدم العلم بهم مثلاً هي ما يُصرف في مصالح المسلمين عند أكثر العلماء، وكذلك من كان عنده مال لا يعرف صاحبه كالغاصب التائب، والخائن التائب، والمرابي التائب ونخوهم من صار بيده مال لا يملكه ولا يعرف صاحبه، فإنه يصرفه إلى

$$
\text { ذوي الحاجات ومصالح المسلمين "(T). }
$$

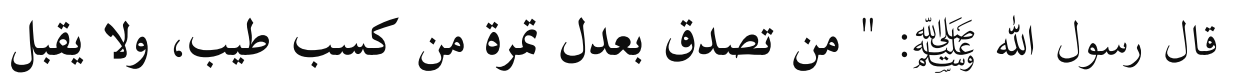

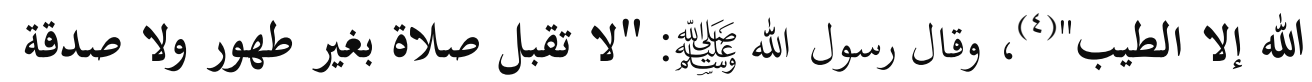
من غلول "(o). فالمال الحرام ينفق على الفقراء والمساكين كما يصرف في المصالح العامة للمسلمين من مدارس ومستشفيات وغيرهما، وليس هذا كله من باب الصدقة، وإنما هو من باب التطهر من المال الحرام وغسله.

(1) وهو قول: الداودي عندما سئل عمن تاب وبيده مال حرام فقال:" قال الداودي: توبته تزيل ما

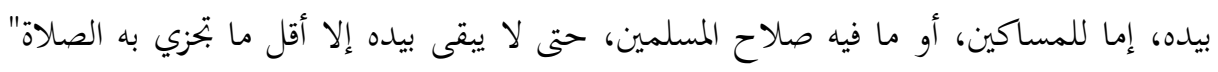

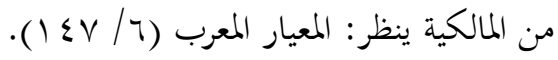

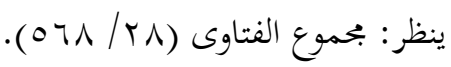

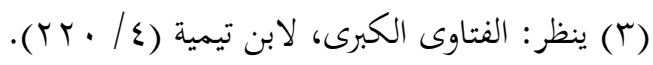

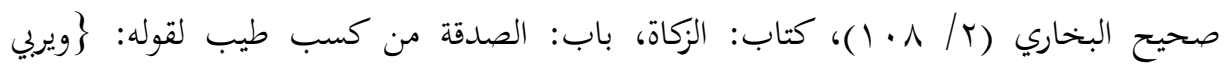

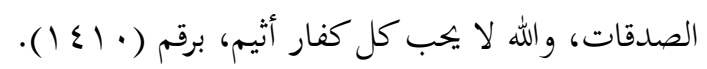

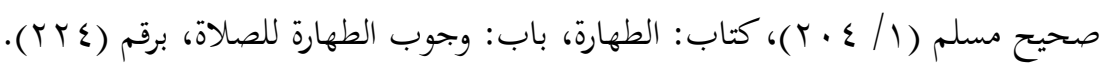


القول الراجح: هو القول الثالث القائل بجواز الانتفاع بالمال الحرام في النفقة على الفقراء والمساكين، والمصالح العامة للمسلمين دون تفريق بينهما؛ وذلك لمال ذكره ابن عبد البر من:" أن رجلا غزا أرض الروم فغلّ عن مائة دينار فأتى بها

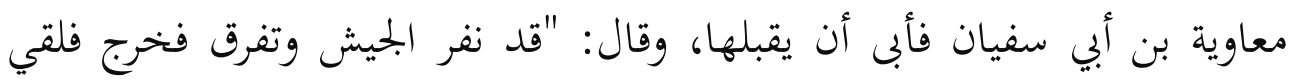

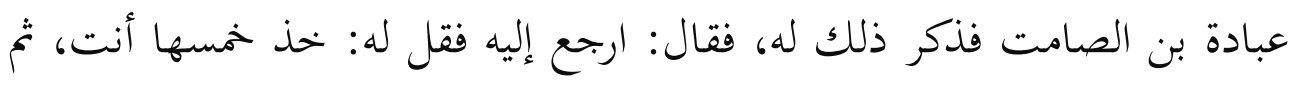

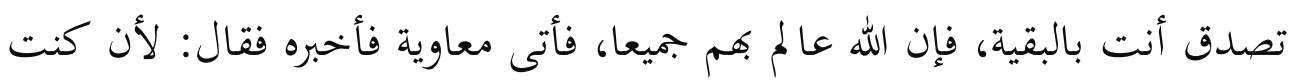

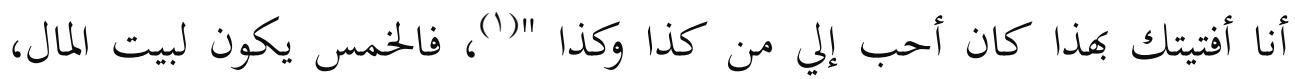
والباقي سيكون للفقراء والمساكين.

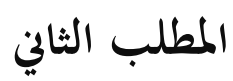

ضوابط قبول المال المفسول، وتطبيقاته في العمل الحيري

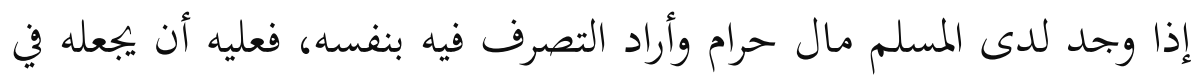
مصارف مشروعة، وكذلك إذا غسل المال الحرام بصرفه إلى المؤسسات القائمة

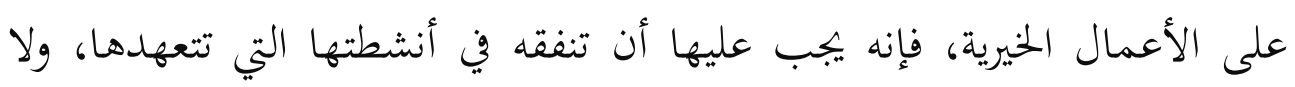
تجعل هذا المال في شيء من أمور العبادات. فالمال الحرام يصح غسله بالصرف إلى الفقراء والمساكين، فيسدون منه إنهاء

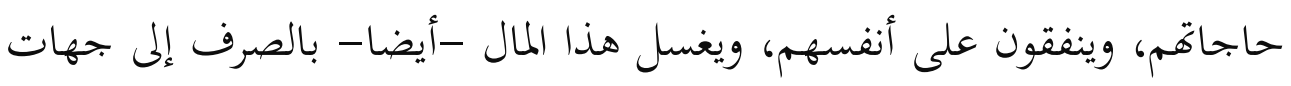

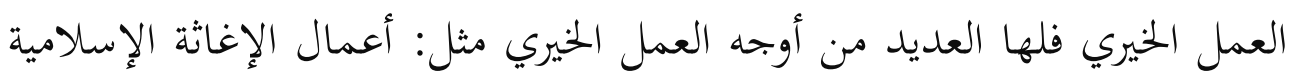

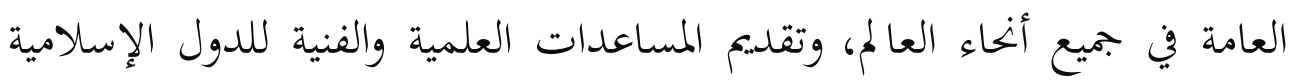
الفقيرة، ودعم المؤسسات التعليمية والاجتماعية الإسلامية، ومساعدة المهجرين

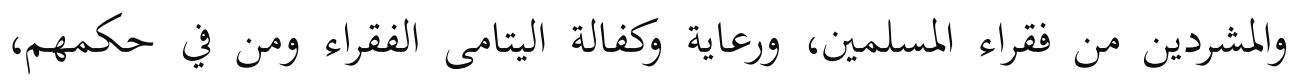

(1) التمهيد لما في الموطأ من المعاني والأسانيد (r/ / ( ). 
وتشييد المرافق ذات المصلحة العامة للناس، وتوصيل وتنقية المياه، وإنشاء مراكز

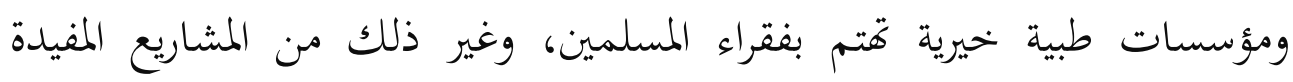
النافعة لعموم المسلمين.

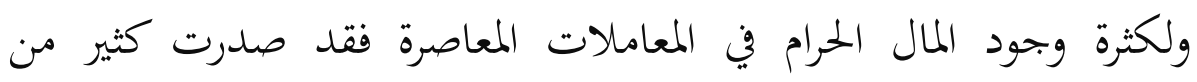
الفتاوى عن بحامع الفقه الإسلامي وقرارات وتوصيات فقهاء وعلماء الاقتصاد الإسلامي، والمصرفية الإسلامية توجب ضرورة الاجتهاد والاحتراز بتقدير المال المكتسب من حرام والتخلص منه في وجوه الخير، وليس بنية التصدق؛ لأن الله

$$
\text { - تعالى - طيب لا يقبل إلا طيبا. }
$$

فمن ذلك: فتوى المؤتمر الثاني للمصرف الإسلامي الذى عقد بدولة

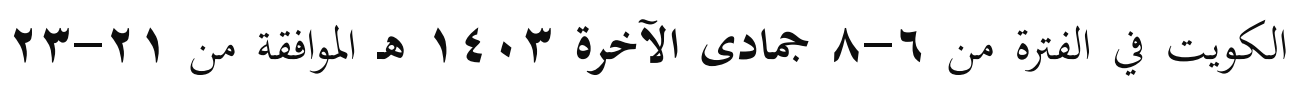
مارس برl91 ونصها: "يوصي المؤتمر أصحاب الأموال من المسلمين بتوجيه

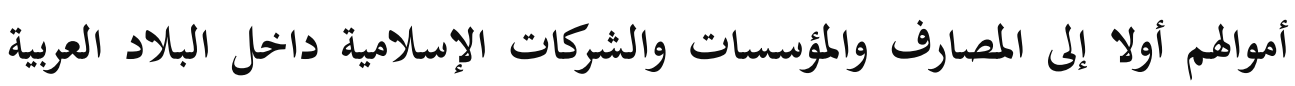

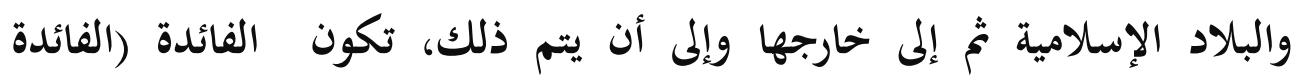
المصرفية) التي يحصلون عليها كسباً خبيثاً وعليهم استيفاؤها والتخلص منها لإنها

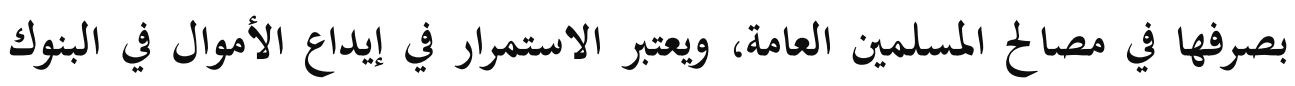
والمؤسسات الربوية مع إمكان تفادى ذلك عملاً محرما شرعاً" (1) .

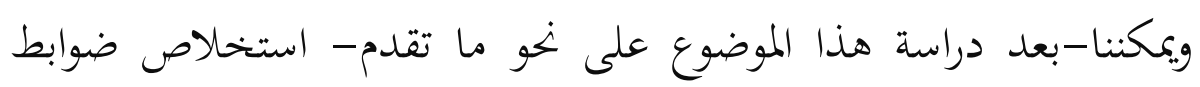
قبول هذه الأموال والانتفاع بما في العمل الخيري، وذلك وفق ماسكو مايلي :

(1) فتوى المؤتمر الثاني للمصرف الإسلامي الذي عقد بدولة الكويت في الفترة من ج-1 همادى الآخرة

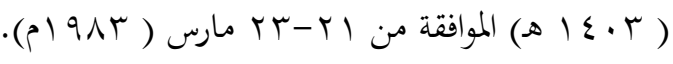

$$
\begin{aligned}
& -7 r^{-}
\end{aligned}
$$


أولا: ألا يُدخل من يقوم بالعمل الخيري هذه الأموال المغسولة في بناء المساجد أو تعميرها أو طباعة المصاحف، وكذلك لا يصح إنفاق هذه الأموال على الأفراد القائمين على العمل الخيري أنفسهم -إلا إذا وجد فيهم الفقير وذو الحاجة-، ولكنها تنفق على الفقراء والمساكين، والمصالح العامة للمسلمين، وجهات الخير المختلفة: كبناء المستشفيات لعلاج المرضى وخصوصا الفقراء والمساكين ، وكبناء المعاهد العلمية، ومحطات تنقية المياه ونحو ذلك مما يعود نفعه على عموم المسلمين، ومن ذلك - أيضانشر الدعوة وبناء المراكز الإسلامية، وإعداد الدعاة والإنفاق عليهم، ونشر الكتب العلمية، وغير ذلك من أوجهه الخير المشروعة. ثانيا: أن تستوثق جهات العمل الخيري من مصدر هذه الأموال المغسولة، وأن تتأكد من أنه لا مالك لها؛ لأنه إذا كان لها مالك وجب ردها إليه. فإذا كانت أصولا ثابتة - كبيت أو عقار أو نحوهما- فإنه يجب عليها أن تأخذ ممن يقدمها لها إقرارا وتنازلا رسميا عن هذه الأموال.

ثالثا: إذا كان الحصول على هذه الأموال المغسولة عن طريق تحويل على حساب بنكي فيجب أن بتعل مؤسسات العمل الخيري حسابا خاصا بها لهذه الأموال؛ فينبغي أن تكون هذه الأموال معلومة، وألا تخلط بغيرها من الأموال، وذلك حتى يمكن عند إنفاقها تمييزها عن غيرها، فتصرف في مصارفها الصحيحة. رابعا: أن يراعي القائم على العمل الخيري سواء أكان فردا أم مؤسسة أن لا لا يكون في استخدام هذا المال المغسول خروج عن النظام المحدد له من قبل ولي الأمر، وأن يكون في إطاره الصحيح الذي حدده الشرع. 


\section{الخاتمة}

\section{وأهم النتائج والثوصيات}

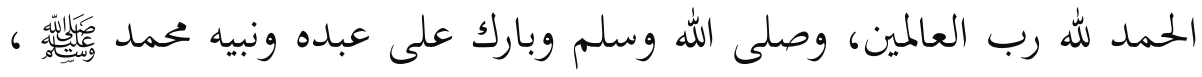
وبعد: فقد توصلت من خلال هذا البحث إلى عدة نتائج وتوصيات، وهي كالتالي :

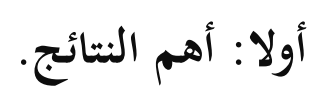

إـ إن مصطلح "غسيل الأموال" غير دقيق ويراد به باطل، وأنه لا يعني الغسل الثرعي الصحيح والواجب: أن يتطهر صاحب المال المكتسب من طرق غير مشروعة من هذا المال بإنفاقه في العمل الخيري إذا لم يعلم مالكه ولم يمكن رده، بل يعني - عند فقهاء القانون المعاصرين - جريمة مركبة من عدة جرائم لا تمت إلى الغسل بصلة بل تقوم على قذارة واضحة " يقوم بمقتضاها أحد الأشخاص بإجراء سلسلةٍ من العمليات المالية المتلاحِقة على أموالٍ غير مشروعة تنتج عن أنشطةٍ غير مشروعة، يُعاقب عليها تشريع الدولة هذا الشخص مستعينا بوسطاء كواجهة للتعامل مُستغلاً مناخ الفساد الإداري وسرية حسابات البنوك بهدف تأمين حصيلة أموالها القذرة من المملاحَقة الرقابية والأمنية ". r- إن المال الحرام هو: المال الذي حظره الشرع لصفة في عينه أو من جهة كسبه، ويمكن تعريفه بأنه: "كل ما حرم الثرع دخوله في ملك المسلم لمانع"، وهو قسمان: المال الحرام لذاته، والمال الحرام لغيره. بـ الأصل في الشرع منع حيازة المال الحرام والانتفاع به، وبتحيم اكتسابه، ووجوب التخلص منه، كما أنه لا يدخل في ملك المسلم حقيقة؛ لأنه لم يدخل في 
حيازته بسبب شرعي صحيح، وقد حرم الشرع بقاءه في يده فضلا عن تحريم وبتريم

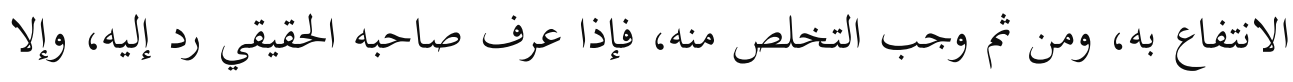
فإنه يجوز غسله في النفقة على الفقراء والمساكين، والمصالح العامة للمسلمين دون

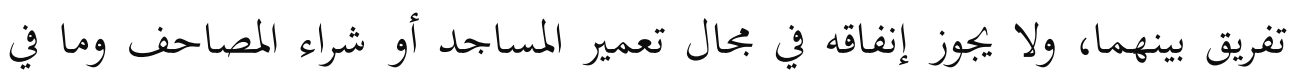

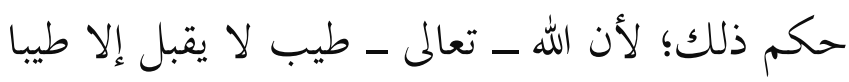

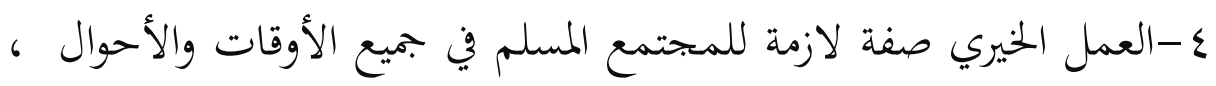

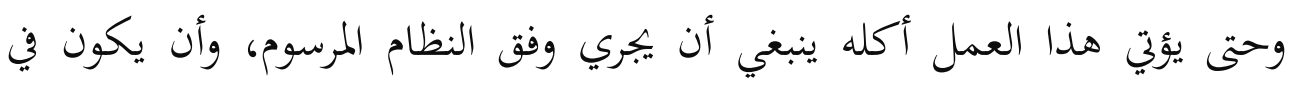
إطاره الصحيح الذي حدده الشرع حتى لا ينحرف عن منهجه وتتجاذبه الأهواء

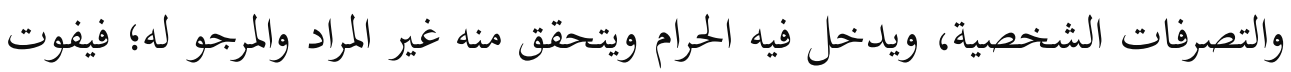
مقصود الشرع منه ويكون سببا في جلب الفساد من حيث أردنا الإصلاح. 0ـ من ضوابط قبول المال الحرام المغسول في العمل الخيري وإنفاقه ما يلي:

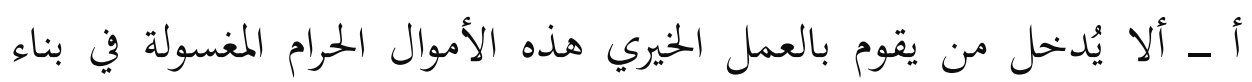
المساجد أو تعميرها أو طباعة المصاحف، وكذلك لا يصح بل إنفاق هذه الأموال

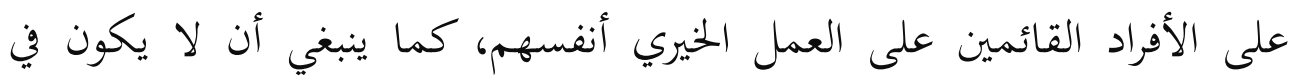
استخدام هذا المال خروج عن النظام المحدد له من قبل ولي الأمر.

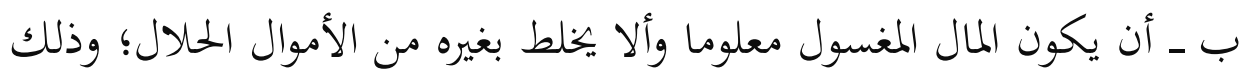
حتى يمكن تمييزه عن غيره. ت ـ أن تستوثق جهات العمل الخيري من أن هذه الأموال لا مالك لها ؛ـ لأنه

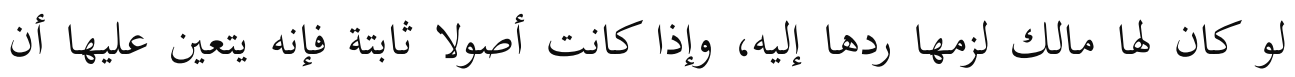
تأخذ ممن يقدمها لها إقرارا وتنازلا رسميا عنها. 


$$
\text { ثانيا: أهم الثوصيات. }
$$

1 - يوصي البحث بتقنين الأعمال الخيرية في الجمتمعات الإسلامية وضبط مواردها ومصارفها وذلك بما يمقق مقاصد الشريعة من تحصيل المصالح وتكميلها وتعطيل المضار وتقليلها ، ويضمن عدم خروجها عن الحدود

$$
\text { المرسومة والأنظمة. }
$$

r- التوسع في نشر ثقافة العمل الخيري في البحتمع المسلم بشتى الوسائل والطرق، ولوسائل الإعلام دور كبير في هذا المجال، مع عدم إهمال دور المؤسسات الأخرى في زرع هذه الثقافة مثل: المسجد، والبيت، والمدرسة، ومن هذه الثقافة التي يبب أن تنشر: معرفة كفية استخدام المال المغسول، والانتفاع به في العمل الخيري وضوابط ذلك. هذا والحمد الله - تعالى - على ما أعان به ووفق من هذا البحث، ونسأله - جل شأنه - أن يجعله عملا خالصا لوجهه الكريم، وأن يكون مما تثقَّل به موازين الحسنات يوم القيامة. و "صلى" الله - تعالى - و "سلم" و "بارك" على نبينا محمد، وعلى آله وصحبه أجمعين.

وكتبه الفقير إلى عفو ربه أحمد بن علي أحمد موافي 


\section{فهرس المصادر والمراجع}

م:القرآن الكريم.

\section{أولا: كتب تثسير القرآن الكريم وملومه :}

1 - تفسير القرآن العظيم (ابن كثير)، أبو الفداء إسماعيل بن عمر بن كثير القرشي البصري ثم الدمشقي (المتوفى: \&VV \&)، المقق: محمد حسين شمس الدين، الناشر: دار الكتب العلمية، منشورات محمد علي بيضون - بيروت،

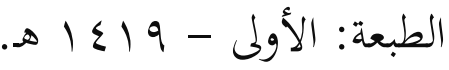

$$
\begin{aligned}
& \text { ثانيا: كتب الحديث وعلومه. }
\end{aligned}
$$

r - التمهيد لما في الموطأ من المعاني والأسانيد، أبو عمر يوسف بن عبد الله بن محمد بن عبد البر بن عاصم النمري القرطبي (المتوفن: rآـهـ) تحقيق: مصطفى بن أحمد العلوي، محمد عبد الكبير البكري الناشر: وزارة عموم الأوقاف والشؤون الإسلامية

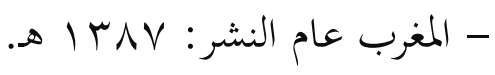

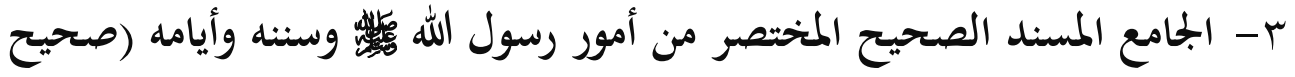
البخاري)، للإمام البخاري، تحقيق: محمد زهير بن ناصر الناصر، دار طوق

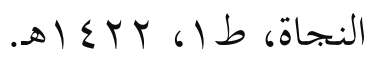
ع - سنن ابن ماجة، أبو عبد الله محمد بن يزيد القزويني (ت

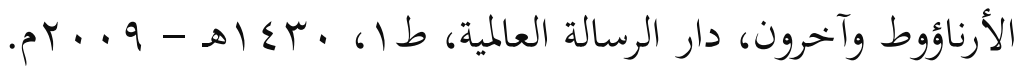
ه- سنن أبي داود، المؤلف: أبو داود سليمان بن الأشعث بن إسحاق بن بشير بن شداد بن عمرو الأزدي السِّجِسْتاني (المتوفى: هYVD)، المحقق: محمد محيي الدين

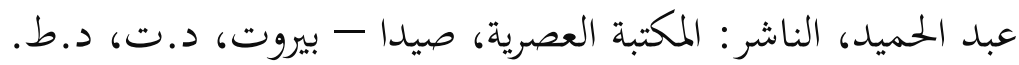
Y- سنن الترمذي، أبو عيسى (ت TV

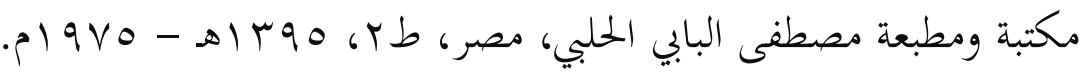


- V السنن الكبرى للبيهقي، المؤلف: أحمد بن الحسين بن علي بن موسى

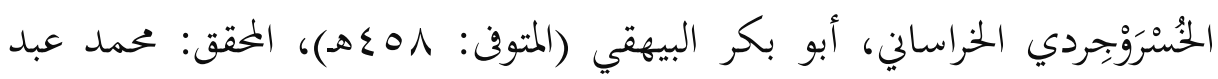
القادر عطا، الناشر: دار الكتب العلمية، بيروت - لبنات، الطبعة: الثالثة، . $r \cdot r-\infty 1 \leqslant r \leqslant$ ^- بجمع الزوائد ومنبع الفوائد ، أبو الحسن نور الدين علي بن أبي بكر بن سليمان

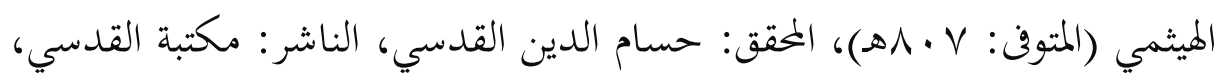

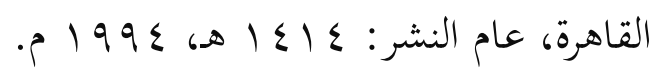
9- المستدرك على الصحيحين، أبو عبد الله الحاكم، المعروف بابن البيع

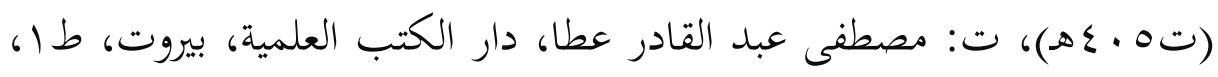

$$
\text { . } 199 \cdot-\infty 1 \leqslant 11
$$

• إ مسند الدارمي المعووف بـ (سنن الدارمي)، أبو محمد عبد الله بن عبد الرحمن بن الفضل بن هَرام بن عبد الصمد الدارمي، التميمي السمرقندي (المتوفن: هم هـ) تحقيق: حسين سليم أسد الداراين الناشر: دار المغني للنشر والتوزيع،

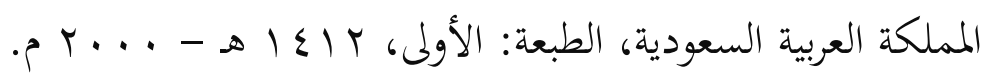
1 - المسند الصحيح المختصر بنقل العدل عن العدل إلى رسول الله مسلم)، تحقيق: محمد فؤاد عبد الباقي، دار إحياء التراث العربي، بيروت، دون

$$
\text { طبعة وتأريخ. }
$$

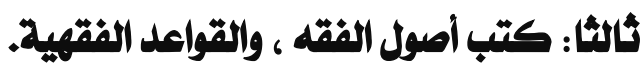

T ا - إرشاد الفحول إلي تحقيق الحق من علم الأصول، محمد بن علي بن محمد ابن عبد الله الشوكاني اليمني (ت: . ه ب اهـ)، المققق: الشيخ أحمد عزو عناية، دمشق- كفر بطنا، قدم له: الشيخ خليل الميس والدكتور ولي الدين

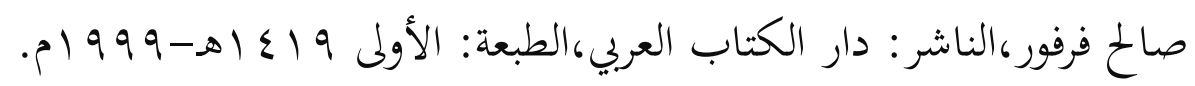


rا - الأشباه والنظائر، تاج الدين عبد الوهاب بن تقي الدين السبكي

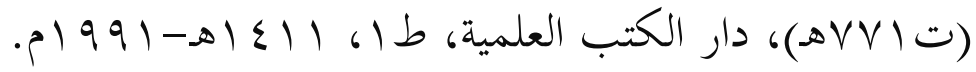

ع ا - الأشباه والنظائر على مذهب أبي حنيفة النعمان، لابن بنيم المصري

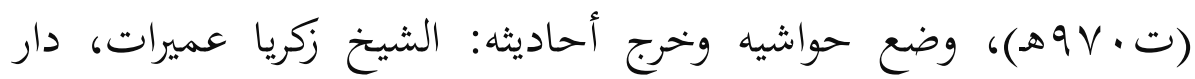

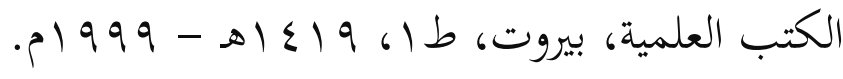

1 - بيان المختصر شرح مختصر ابن الحاجب، محمود بن عبد الرحم (أبي القاسم) ابن أحمد بن محمد، أبو الثناء، شمس الدين الأصفهاني (المتوفى:

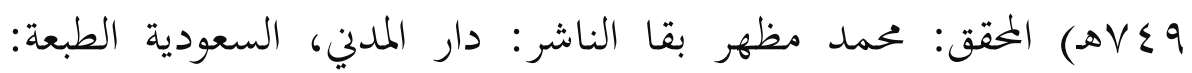

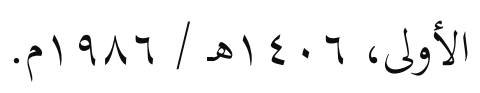

1 ا - التحبير شرح التحرير في أصول الفقه، علاء الدين أبو الحسن علي بن

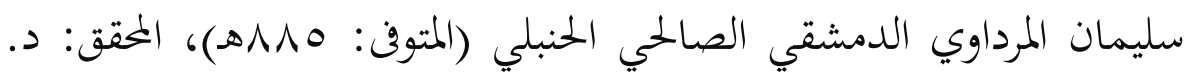

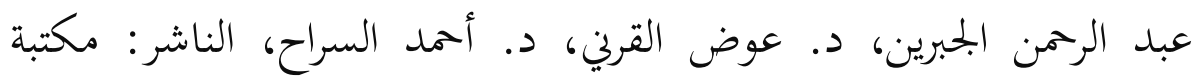

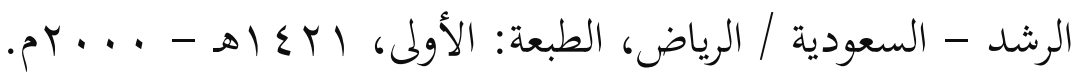
IV

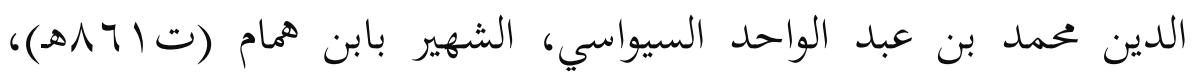

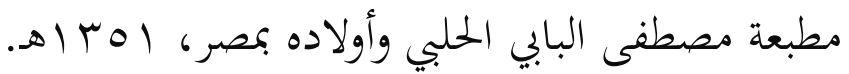

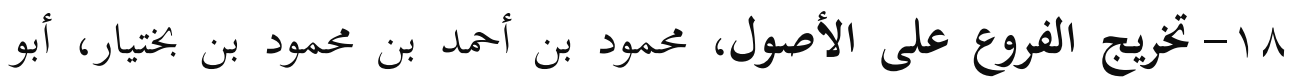

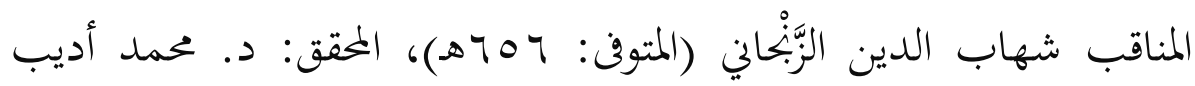

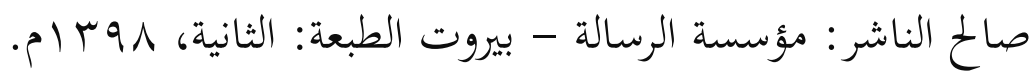


19 - تشنيف المسامع بجمع الجوامع، لتاج الدين السبكي، دراسة وتحقيق: د.سيد عبد العزيز، د. عبد الله ربيع، مكتبة قرطبة للبحث العلمي وإحياء

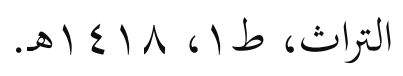

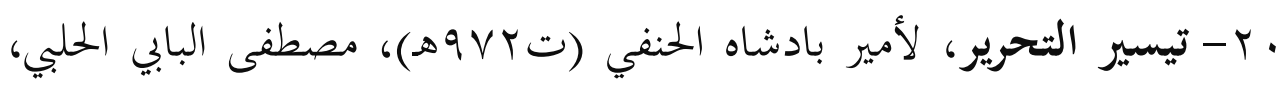

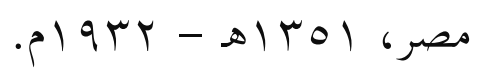

ا ا - حاشية العطار على شرح الجلال المحلي على جمع الجوامع، البنّاني ،طبعة

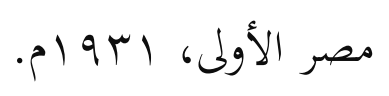

Y Y- روضة الناظر وجنة المناظر، لابن قدامة، ط: مؤسسة الريّان، ط: الثانية،

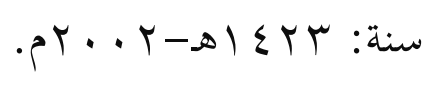

بr- شرح التلويح على التوضيح، سعد الدين مسعود بن عمر التفتازاني (المتوفى: بو Vهـ) الناشر: مكتبة صبيح بمصر، بدون طبعة وبدون تاريخ.

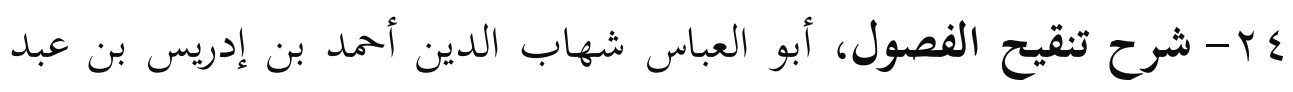

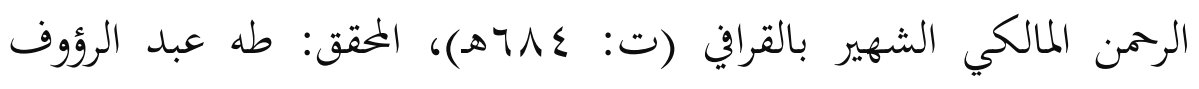

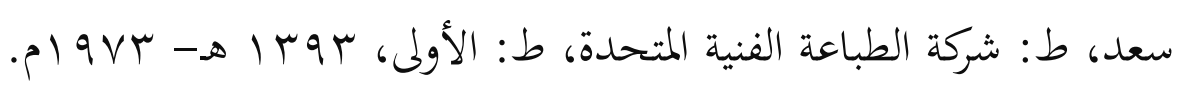

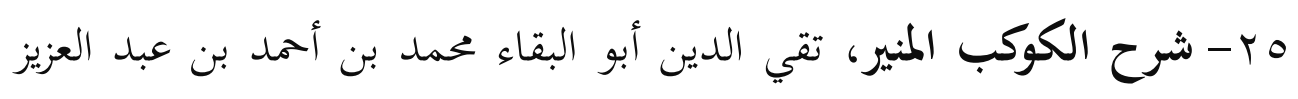

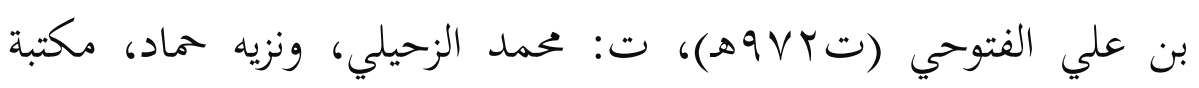

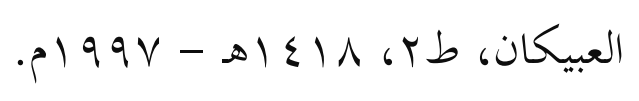

جr- شرح مخنصر الروضة، سليمان بن عبد القوي بن الكريم الطوفي الصرصري،

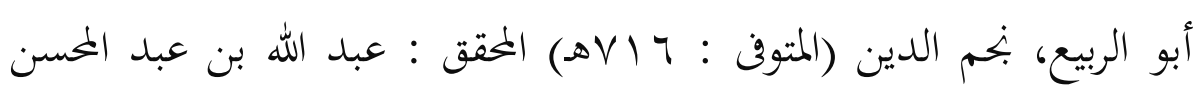

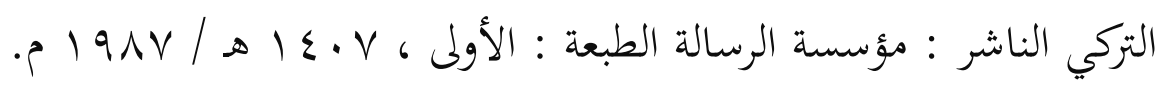


V TV - قواطع الأدلة في الأصول، أبو المظفر، منصور بن محمد بن عبد الجبار ابن

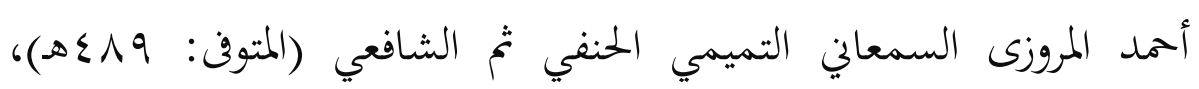

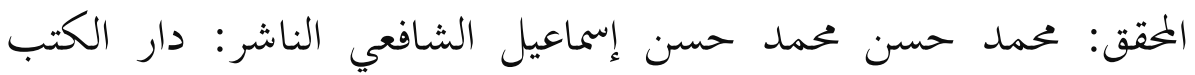

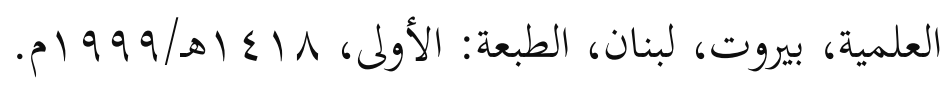
人 رجب بن الحسن، السَلامي، البغدادي، ثم الدمشقي، الحنبلي (المتوفن:

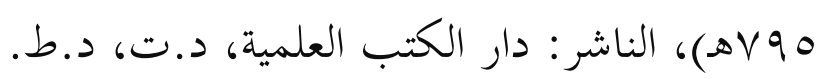
وץ- القواعد الفقهية، المبادئ- المقومات، يعقوب بن عبد الوهاب الباحسين،

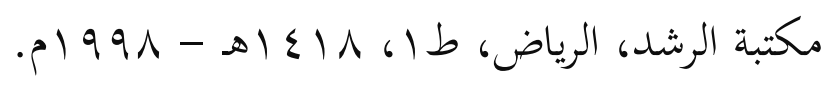

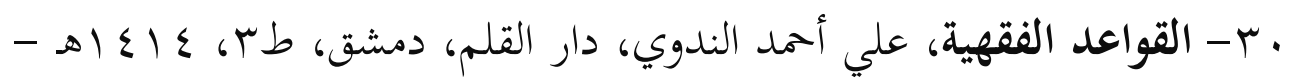
$.0199 \varepsilon$

اب- الخصول في علم الأصول، محمد بن عمر بن الحسين الرازي، الناشر:

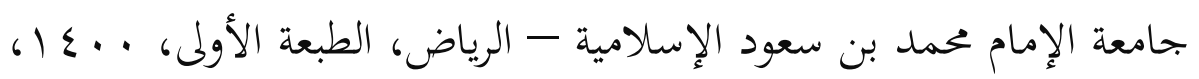
تحقيق: طه جابر فياض العلواني.

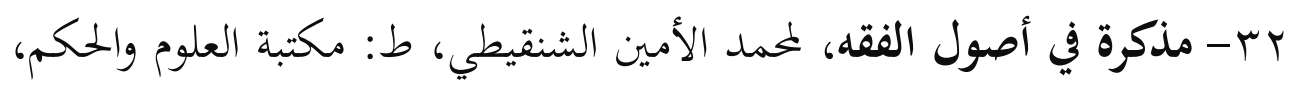

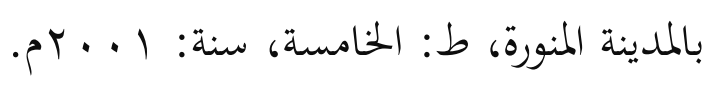
rr- المثثور في القواعد الفقهية، الزركشي (ت بـ ولهـ)، وزارة الأوقاف الكويتية،

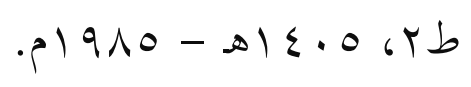
ع ז- الموافقات، إبراهيم بن موسى بن محمد اللخمي الغرناطي الشهير بالشاطبي

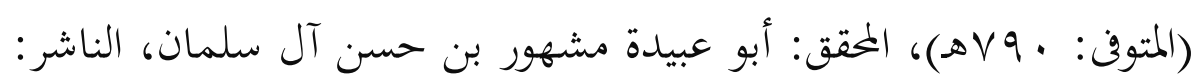

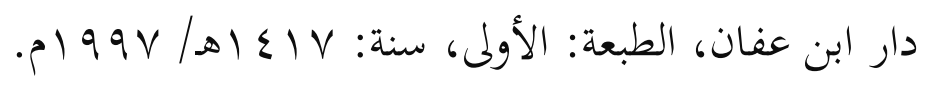


هـ- الوجيز في أصول الفقه الإسلامي، الأستاذ الدكتور محمد مصطفى الزحيلي، الناشر: دار الخير ، دمشق - سوريا، الطبعة: الثانية، VY I I هـ -

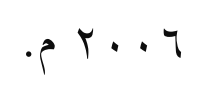

\section{كابعا: كثب الثقته:}

\section{أ- كتب الفقه الحنفي:}

جب- الاختيار لتعليل المختار، عبد الله بن محمود بن مودود الموصلي البلدحي، بحد الدين أبو الفضل الحنفي (المتوفن: بربهـ)،عليها تعليقات: الشيخ

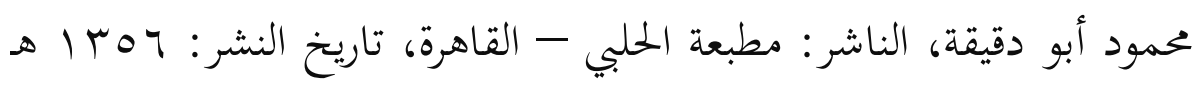

$$
\text { • } 19 \mu \mathrm{V}-
$$

V V- بدائع الصنائع في ترتيب الشرائع، علاء الدين، أبو بكر بن مسعود بن أحمد الكاساني الحنفي (المتوفى: NV Vه)، الناشر: دار الكتب العلمية،

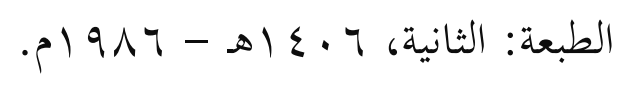

مب- البناية شرح الهداية، أبو محمد محمود بن أحمد بن موسى بن أحمد بن

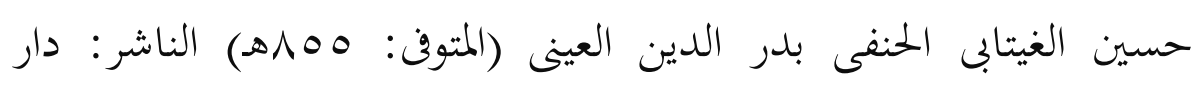

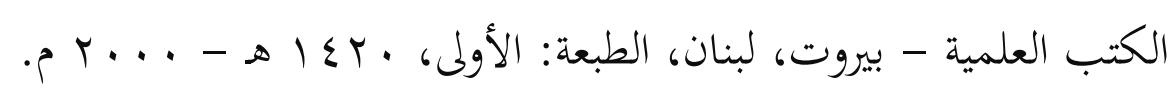

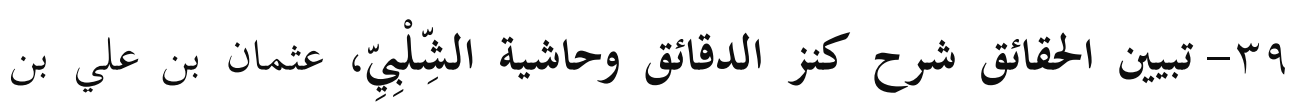
محجن البارعي، فخر الدين الزيلعي الحنفي (المتوفى: r V هـ)، الحاشية: شهاب الدين أحمد بن محمد بن أحمد بن يونس بن إسماعيل بن يونس

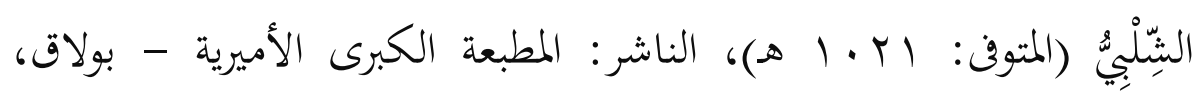

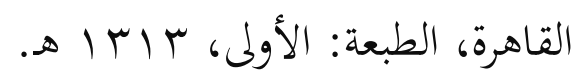


• ع- رد المحتار على الدر المختار ، ابن عابدين، محمد أمين بن عمر بن عبد العزيز عابدين الدمشقي الحنفي (المتوفن: بor اهـ) الناشر: دار الفكر بيروت الطبعة: الثانية، ب إع اهـ - r 999 | م. إ - الفتاوى المندية، لجنة علماء برئاسة نظام الدين البلخي، الناشر: دار الفكر، الطبعة: الثانية . اسب هـ. ץ - المبسوط، للسرخسي (تrم乏ه)، دار المعرفة، بيروت، دون طبعة، $. p|99 \mu-\Delta| \varepsilon \mid \varepsilon$ بـ - الخحيط البرهائ في الفقه النعماني، أبو المعالي برهان الدين محمود بن أحمد ابن عبد العزيز بن عمر بن مَازَة البخاري الحنفي (المتوفى: 7 الجهـ)، المحقق: عبد الكريم سامي الجندي، الناشر: دار الكتب العلمية، بيروت - لبنان،

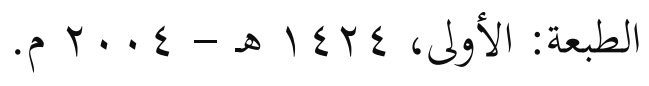

§؟ - المداية شرح بداية المبتدي، علي بن أبي بكر بن عبد الجليل الفرغاني المرغيناني، أبو الحسن برهان الدين (المتوف: بوهـه)، الناشر: المكتبة الإسلامية .

\section{ب-كتب الفقه المالكي:}

هـ - أسهل المدارك 》شرح إرشاد السالك في مذهب إمام الأئمة مالك《، المؤلف: أبو بكر بن حسن بن عبد الله الكشناوي (المتوف: VQ Vا هـ)، الناشر: دار الفكر، بيروت - لبنان، الطبعة: الثانية، د.ته، د.ط. جـ - الإشراف على نكت مسائل الحخلاف، للقاضي عبد الوهاب بن علي بن نصر البغدادي المالكي (r \& \&ه)، تحقيق: الحبيب بن طاهر، دار ابن حزم،

$$
\text { . } 1999-81 \leqslant r \cdot 61 b
$$


V V - البيان والتحصيل والشرح والتوجيه والتعليل لمسائل المستخرجة، المؤلف:

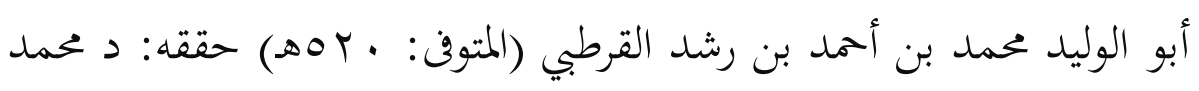
حجي وآخرون الناشر: دار الغرب الإسلامي، بيروت - لبنان الطبعة:

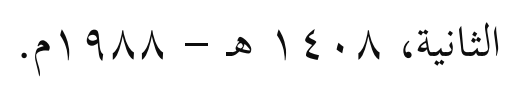

^§ - التبصرة، علي بن محمد الربعي، أبو الحسن، المعروف باللخمي (المتوفى:

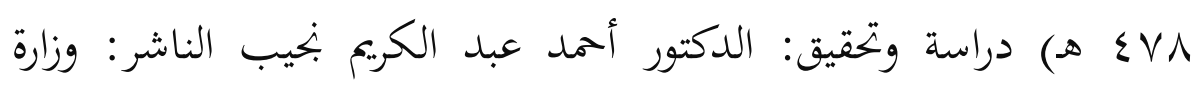

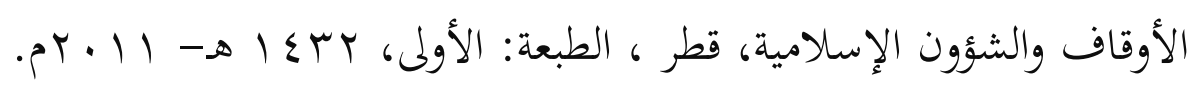

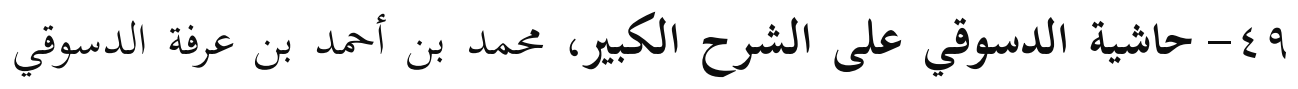

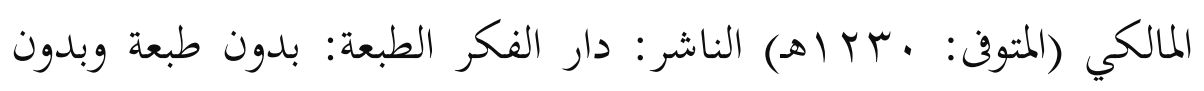
تاريخ.

• ه- الذخيرة، أبو العباس شهاب الدين أحمد بن إدريس بن عبد الرحمن المالكي

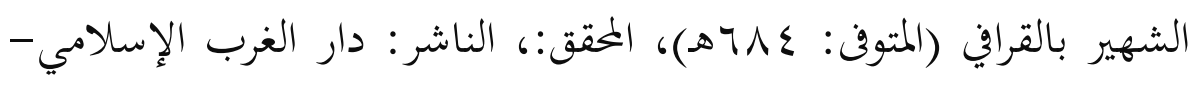

$$
\text { بيروت، الطبعة: الأولى، ع9 } 99 \text { ام. }
$$

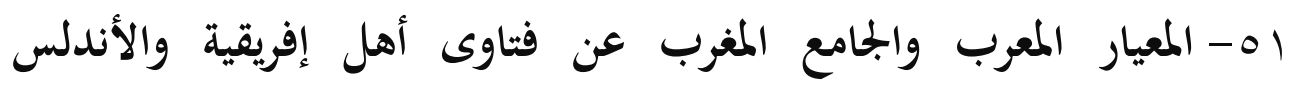

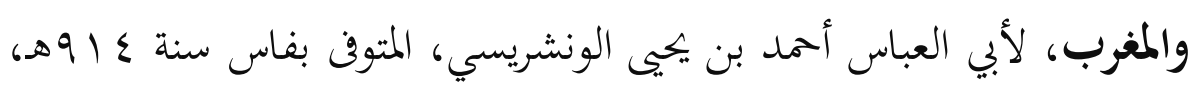

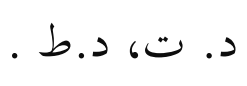

\section{ج-كتب الفقه الشافعي:}

ro - أسنى المطالب في شرح روض الطالب، زكريا بن محمد بن زكريا الأنصاري،

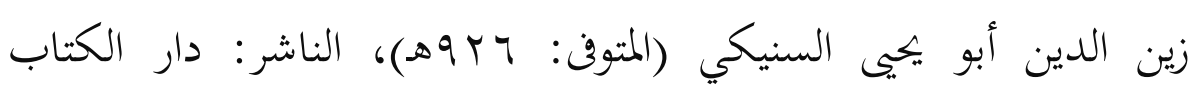
الإسلامي، الطبعة: بدون طبعة وبدون تاريخ. 
rه- تحفة الحختاج في شرح المنهاج، المؤلف: أحمد بن محمد بن علي بن حجر

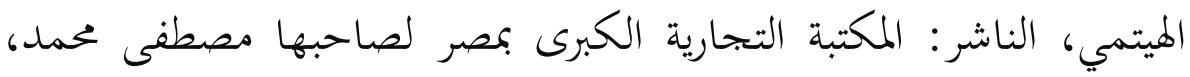

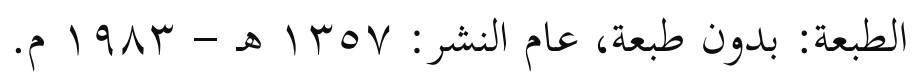

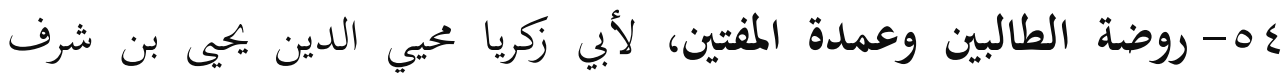

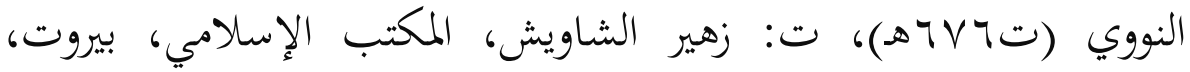

$$
\text { ط طب، }
$$

0- الجموع شرح المهذب، للنووي (ت7V7هـ)، دار الفكر، دون طبعة وتأريخ.

7ه - مغني المختاج إلى معرفة معالي ألفاظ المنهاج، شمس الدين، محمد بن أحمد

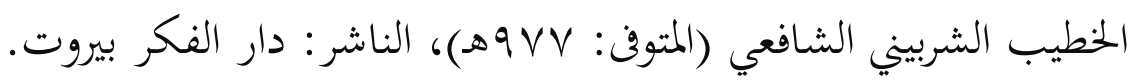

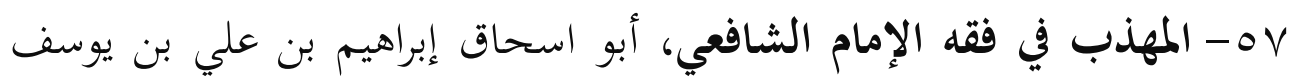

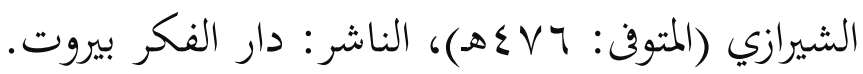

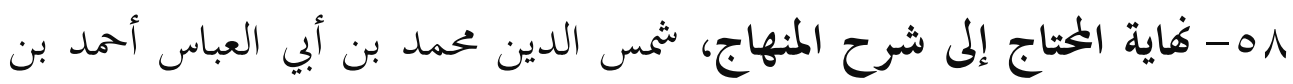

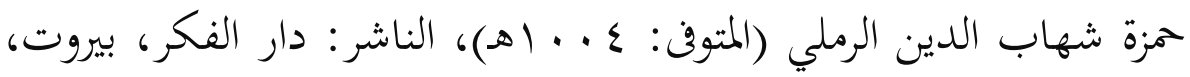

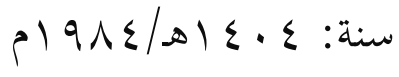

$$
\begin{aligned}
& \text { د-كتب الفقه الحنبلي: }
\end{aligned}
$$

9ه- دقائق أولي النهى لشرح المنتهى المعروف بشرح منتهى الإرادات،

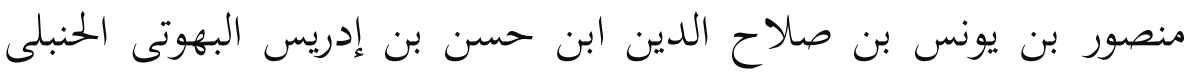

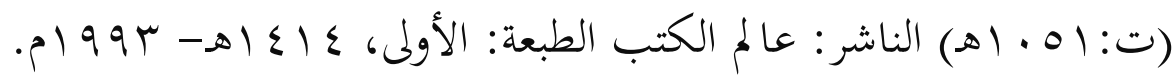


• ؟- كشاف القناع عن متن الإقناع، منصور بن يونس بن صلاح الدين ابن

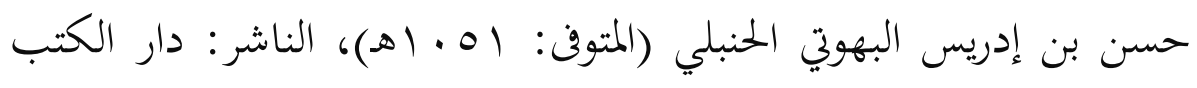
العلمية.

ال7- مسائل الإمام أحمد رواية أبي داود السجستاني، أبو داود سليمان بن الأشعث بن إسحاق بن بشير بن شداد بن عمرو الأزدي السِّنِِسْتاني

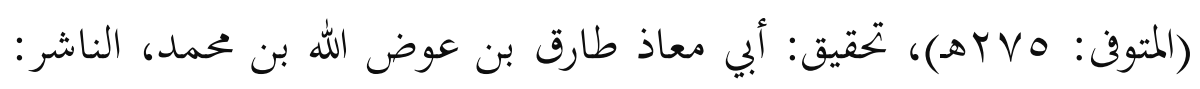

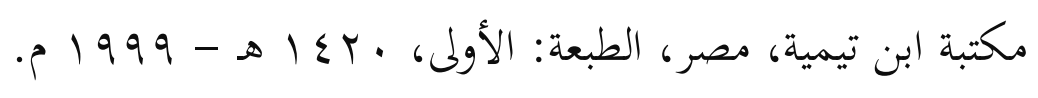

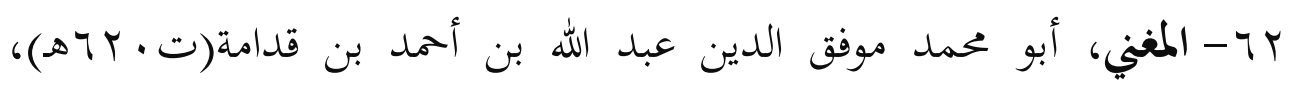

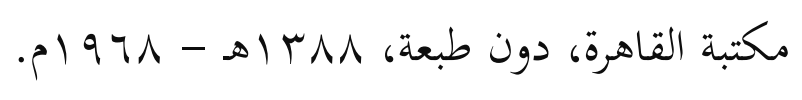

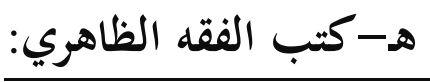

با7- المحلى بالآثار، أبو محمد علي بن أحمد بن بن سعيد بن حزم الأندلسي القرطبي

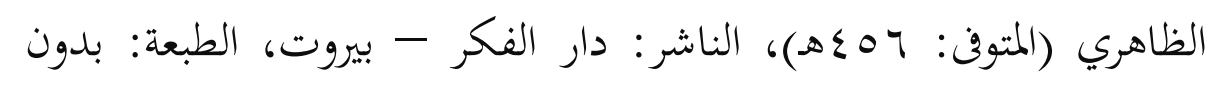

$$
\text { طبعة وبدون تاريخ. }
$$

\section{و -كتب الفقه العام، وتاريخ الفقه:}

ع آ- صيد الخاطر، جمال الدين أبو الفرج عبد الرحمن بن علي بن محمد الجوزي

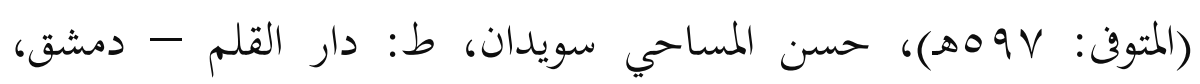

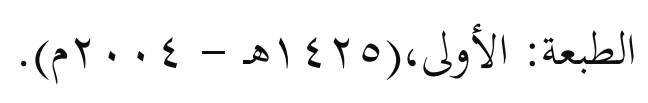

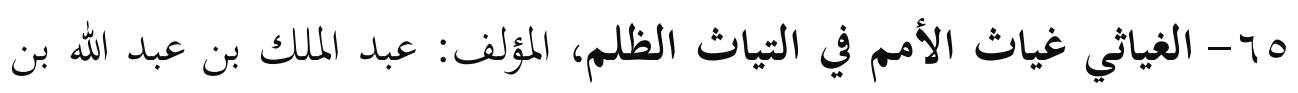

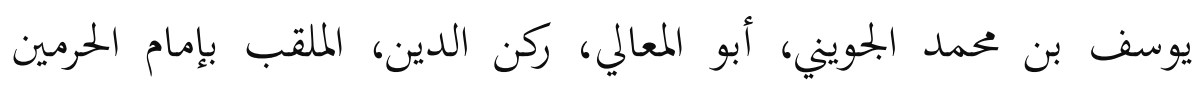




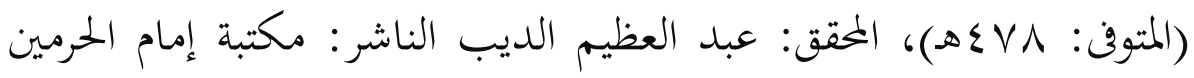

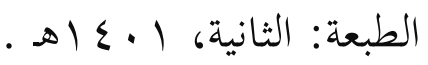

7 7 - الفتاوى الكبرى، تقي الدين أبو العباس أحمد بن عبد الحليم بن عبد السلام ابن تيمية الحرائ الحنبلي الدمشقي (المتوفى: VYNA)، الناشر: دار

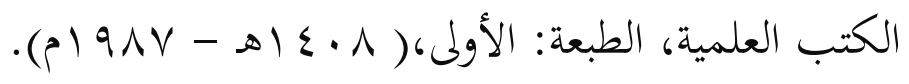

VV - Y Vموع الفتاوى، تقي الدين أبو العباس أحمد بن عبد الحليم بن تيمية الحراين

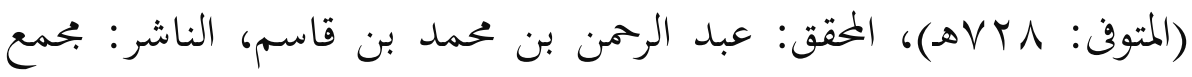
الملك فهد لطباعة المصحف الشريف، المدينة النبوية، المملكة العربية

$$
\text { السعودية، عام النشر: } 7 \text { إع اهـ/ } 990 \text { |م. }
$$

1^ - المذهب الحنبلي دراسة في تاريخه وسماته، د/ عبد الله بن عبد المحسن بن عبد الرحمن التركي، الناشر: مؤسسة الرسالة ناشرون، الطبعة: الأولى،

$$
\cdot(r \cdot r \cdot r=\Delta \quad 1 \leqslant r r)
$$

\section{ز-كتب وبكوث معاصرة في الفقه والاقتصاد الإسلامي:}

79- اتفاقية الأمم المتحدة لمكافحة الجريمة المنظمة عبر الوطنية اعتمدت وعرضت للتوقيع والتصديق والانضمام بموجب قرار الجمعية العامة للأمم المتحدة ه ب الدورة الخامسة والخمسون المؤرخ في ه 1 تشرين الثاني/ نوفمبر . . . . . • . د.عباس أحمد الباز ، مراجعة، أ.د/ عمر سليمان الأشقر، طبعة: دار النفائس، الطبعة: الأولى، سنة: 1 إـ اهـ. ا V- جريمة غسل الأموال في الفقه الإسلامي، د. عطية فياض، دار النشر للجامعات. 
- VY

$$
\text { الرشاد الإسلامية - بيروت. }
$$

r العمل النطوعي في السنة النبوية: دراسة موضوعية، الباحثة: رندا محمد

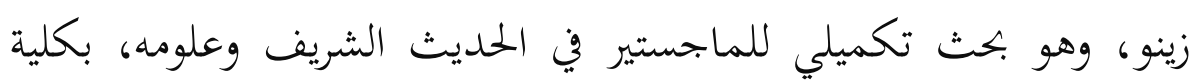

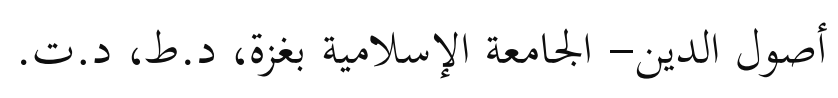

ع

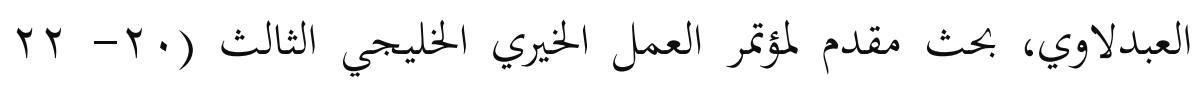

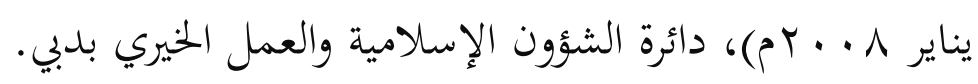

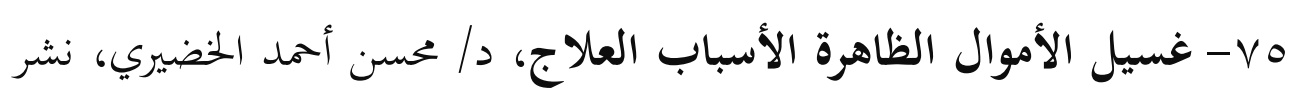

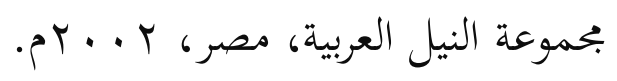

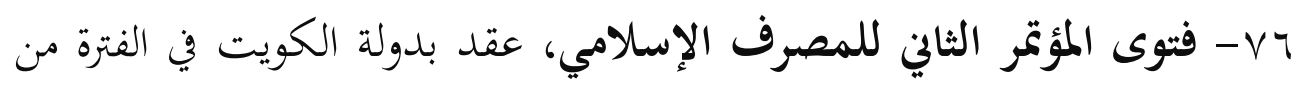

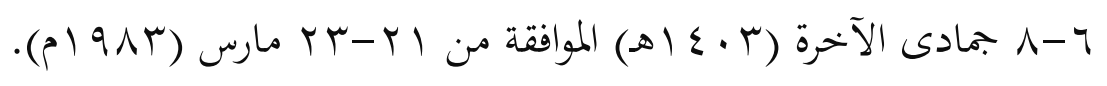

VV المصارف معاملاتما وودائعها للشيخ مصطفى الزرقا، منشورات المركز

$$
\text { العالمي لأبحاث الاقتصاد الإسلامي-جدة. }
$$

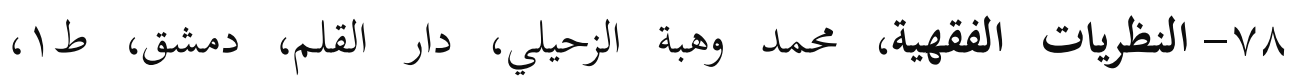

$$
\text { . }
$$

\section{خامسا: كتب معاجم اللغل، والاصطلاحات الفقهية.}

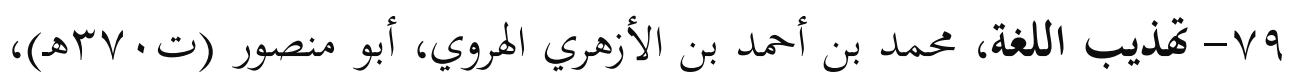

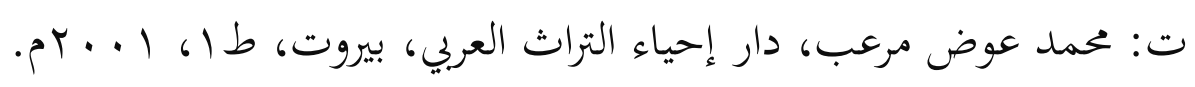

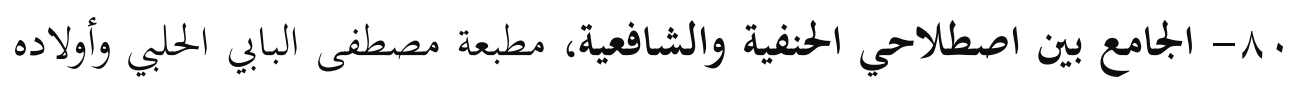

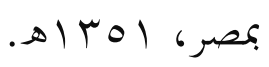


ا ا- جمهرة اللغة، لابن دريد (اTMه)، ت: رمزي منير بعلبكي، دار العلم

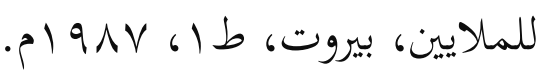

r ب - الصحاح تاج اللغة وصحاح العربية، المؤلف: أبو نصر إسماعيل بن حماد الجوهري الفارابي (المتوفى: بوهبه) تحقيق: أحمد عبد الغفور عطار الناشر:

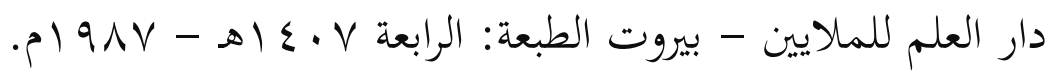

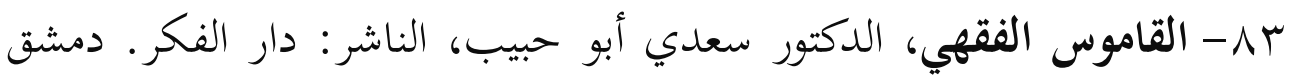

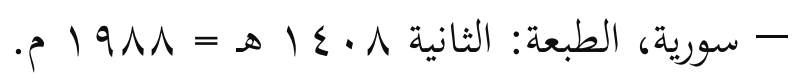

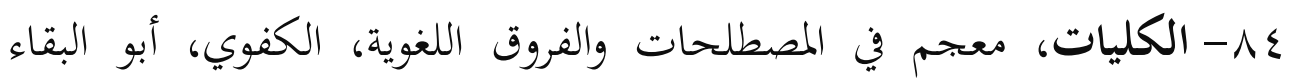
الحنفي (ت؟9 · اهـ)، تحقيق: عدنان درويش، ومحمد المصري، مؤسسة

$$
\text { الرسالة، بيروت، دون طبعة وتأريخ. }
$$

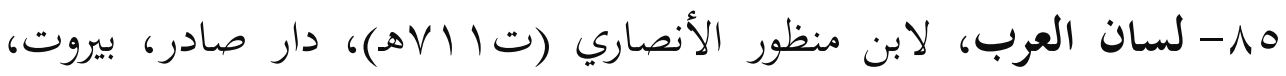
طץ،

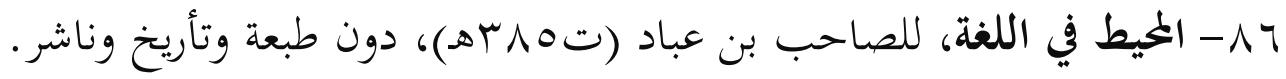
NV

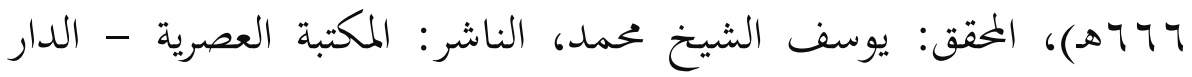

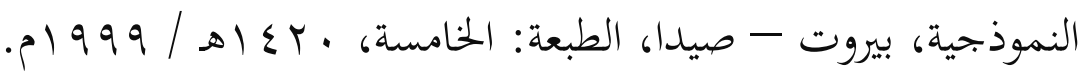

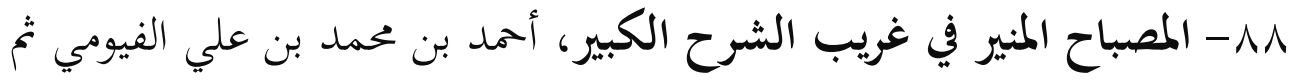
الحموي، (ت نحو • لوVه)، المكتبة العلمية، بيروت، دون طبعة وتأريخ.

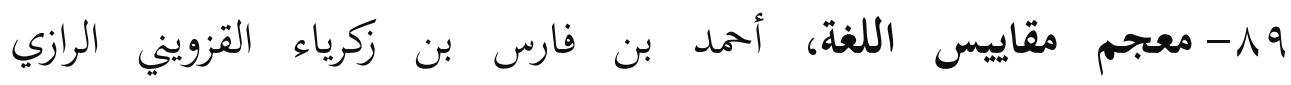

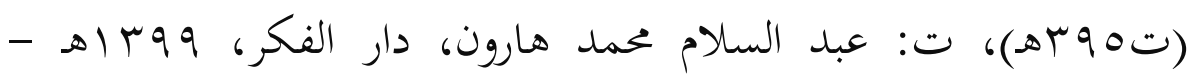


• 9- المعجم الوسيط، إبراهيم مصطفى وأحمد الزيات، ت: بحمع اللغة العربية،

$$
\text { دار الدعوة، الإسكندرية، دون طبعة وتأريخ. }
$$

\section{سادسا: كتب السير والتزاجم.}

ا 9- الأعلام، خير الدين بن محمود بن محمد بن علي بن فارس، الزركلي،

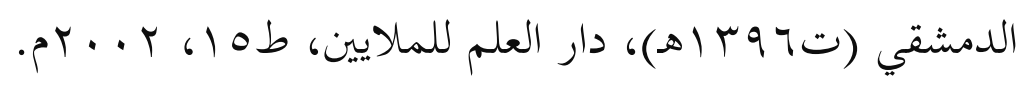

r

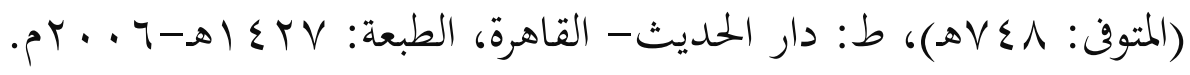

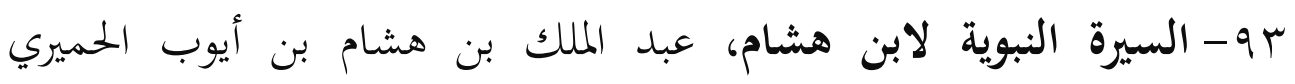

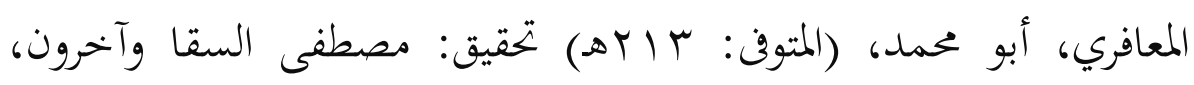

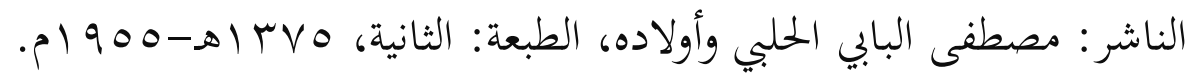

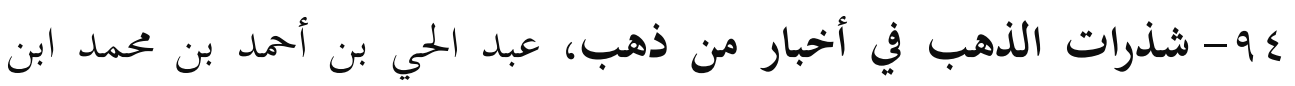

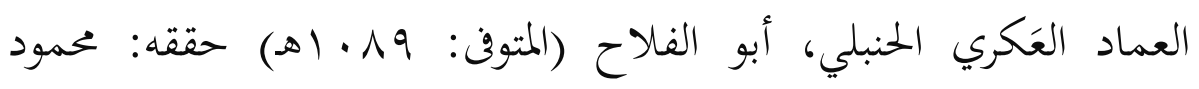

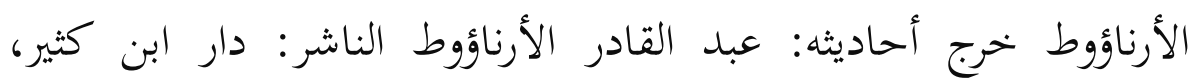

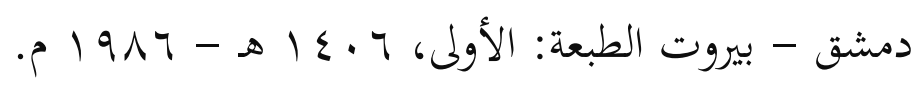

90 - معجم المؤلفين، عمر بن رضا بن محمد راغب بن عبد الغني كحالة

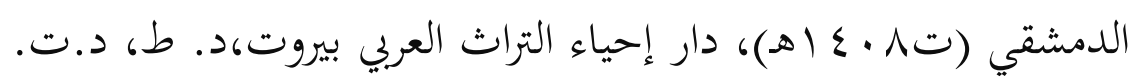




\section{فهرس الموضوعـــات}

\begin{tabular}{|c|c|}
\hline رقم الصفحة & الموضـــــــوع \\
\hline ir & المقدمة \\
\hline 17 & المبحث الأول: التعريف بالمصطلحات الواردة في عنوان البحث، \\
\hline 17 & المطلب الأول: مفهوم غسيل الأموال الحرام \\
\hline 17 & أولا: مفهوم غسيل الأموال: \\
\hline 17 & أ-أغسيل لغة \\
\hline iv & ب-الغسيل في الاصطلاح \\
\hline 11 & غسيل الأموال اصطلاحا عند علماء القانون والاقتصاد \\
\hline 19 & *قوجهة البحث في مصطلح "غسيل الأموال" \\
\hline 19 & ت ت غسل الأموال في الشرع \\
\hline r. & *شلاصة وجهة البحث في "مصطلح غسيل الأموال" \\
\hline rI & ثانيا: تعريف الأموال الحرام \\
\hline r) & أ-تعريف المال لغة واصطلاحا \\
\hline r) & تعريف المال لغة \\
\hline r) & تعريف المال اصطلاحا \\
\hline rr & مثاختلاف الفقهاء في اعتبار المنافع مالا \\
\hline$r \varepsilon$ & ب-تعريف الحرام لغة واصطلاحا \\
\hline ro & الحرام اصطلاحا \\
\hline
\end{tabular}




\begin{tabular}{|c|c|}
\hline$r 7$ & المطلب الثاني: التعريف بالعمل الحخيري \\
\hline r人 & تعقيب على تعريف العمل الخيري \\
\hline$r$. & المطلب الثالث: تعريف الحكم والضوابط لغة واصطلاحا \\
\hline$r$. & أولا: تعريف الحكم لغة واصطلاحا. \\
\hline r. & الحكم لغة \\
\hline r. & الحكم اصطلاحا \\
\hline r & ثانيا: تعريف الضوابط لغة واصطلاحا. \\
\hline ו & الضوابط لغة \\
\hline rt & الضوابط اصطلاحا \\
\hline ry & المبحث الثاين : أقسام المال الحرام، وأهم صوره ، وفيه مطلبان: \\
\hline 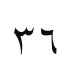 & المطلب الأول: أقسام المال الحرام. \\
\hline ru & القسم الأول: المال الحرام لذاته \\
\hline r人 & القسم الثاني: المال الحرام لغيره \\
\hline rq & المطلب الثاني: صور المال الحرام. \\
\hline$\varepsilon r$ & المبحث الثالث : التأصيل الثرعي لقبول المال المغسول والانتفاع به \\
\hline$\varepsilon r$ & المطلب الأول: بيان أن الأصل في الشرع منع حيازة المال الحرام والاننفاع \\
\hline$\varepsilon 7$ & المطلب الثاين: احتمالات التخلص من ملكية المال المغسول والتصرف فيه. \\
\hline$\varepsilon\urcorner$ & الاحتمال الأول: أن يبقى المال الحرام في يد صاحبه المكتسب له من غير الطرق \\
\hline$\sum \uparrow$ & الاحتمال الثاني: أن يترك صاحب هذا المال الحرام ماله لمن يتعامل معه. \\
\hline
\end{tabular}




\begin{tabular}{|c|c|}
\hline$\varepsilon V$ & الاحتمال الثالث: أن يتخلّص من يجصل على المال الحرام منه ولا ينتفع به، وذلك عن طريق إتلافه أو إحراقه أو إلقائه في البحار \\
\hline$\leqslant q$ & الاحتمال الرابع: أن يبحث صاحب هذا المال الحرام عن مصرف أو عمل شئ خيري ينفق فيه هذا المال \\
\hline 0 . & **رأي شيخ الإسلام ابن تيمية في كيفية إنفاق هذا المال. \\
\hline o乏 & 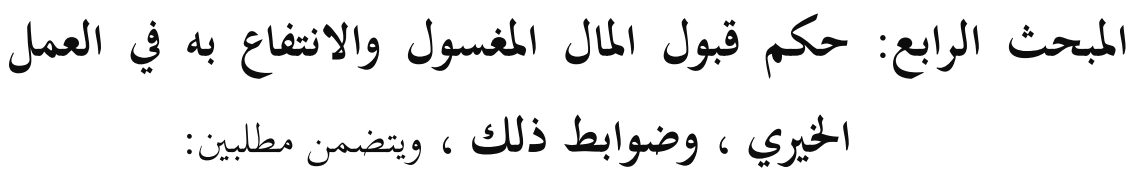 \\
\hline $0 \leqslant$ & المطلب الأول: حكم قبول المال المغسول والانتفاع به في العمل الحخيري. \\
\hline 00 & أولا: حكم استخدام المال الحرام في بناء المساجد أو شراء المصاحف أو \\
\hline 09 & ثانيا: حكم غسل المال الحرام في النفقة على الفقراء والمساكين، والمصاح \\
\hline$\pi T$ & المطلب الثاني: ضوابط قبول المال المفسول، وتطبيقاته في العمل الخيري. \\
\hline 70 & الخاتمة: أهم النتائج والتوصيات . \\
\hline 71 & فهرس المصادر والمراجع \\
\hline Ar & فهرس الموضوعات \\
\hline
\end{tabular}

